\title{
Studi Positioning Layanan Komunitas pada Program Pengendalian HIV dalam Sistem Kesehatan Nasional (SKN)
}

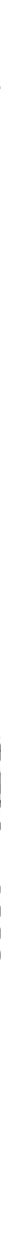

\section{Penulis}

Aang Sutrisna

Pande Putu Januraga

Jaclyn Angelina Kaunang

Aditya Wardhana

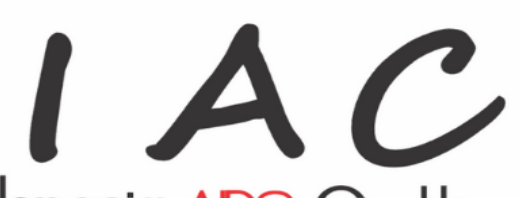

Indonesia ADS Coalition 


\title{
Studi Positioning Layanan Komunitas pada Program Pengendalian HIV dalam Sistem Kesehatan Nasional (SKN)
}

\author{
Penulis: \\ Aang Sutrisna \\ Pande Putu Januraga \\ Jaclyn Angelina Kaunang \\ Aditya Wardhana
}

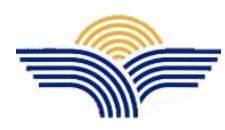

PENERBIT

BASWARA PRESS by PANUDUH ATMA WARAS

Jl. ByPass Ngurah Rai Nomor: 888 xx, Denpasar, Bali - Indonesia

(0361) 6209990; (+62)82236180725

info@baswarapress.com

panuduhatmawaras@gmail.com 


\section{Laporan Hasil}

\section{Studi Positioning Layanan Komunitas pada Program Pengendalian HIV dalam Sistem Kesehatan Nasional}

Penulis:

Aang Sutrisna

Pande Putu Januraga

Jaclyn Angelina Kaunang

Aditya Wardhana

ISBN : : 9786239747312

ISBN (PDF) : 9786239747305

Copyright (C) Februari 2021

Ukuran $: 21 \mathrm{~cm} \times 29.7 \mathrm{~cm}$; iii + 90 halaman

Hak Cipta dilindungi oleh Undang-Undang. Pertama kali diterbitkan di Indonesia dalam Bahasa Indonesia oleh Baswara Press. Penggunaan material dalam karya ini diatur dalam Lisensi Publik Creative Commons 4.0 Atribusi-NonKomersial-TanpaTurunan (CC-BY-ND). Pengguna dapat mengutip konten dalam karya ini dengan memberi kredit yang sepantasnya kepada penulis asli karya ini. Dilarang menggunakan karya ini untuk kepentingan komersial dalam bentuk apapun. Dilarang mengubah dan menyebarluaskan isi karya ini dalam bentuk apa pun tanpa izin tertulis dari penulis.

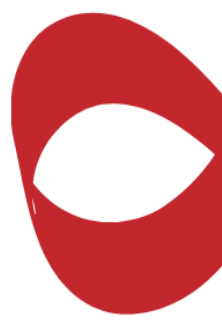

Cetakan, Juli 2021

\section{PENERBIT}

BASWARA PRESS by PANUDUH ATMA WARAS

Jl. ByPass Ngurah Rai Nomor: 888 xx, Denpasar, Bali - Indonesia

(0361) 6209990; (+62)82236180725

info@baswarapress.com

panuduhatmawaras@gmail.com 


\section{Kata Pengantar}

Sejalan dengan pemikiran-pemikiran global serta telaahtelaah upaya pengendalian HIV dunia, Indonesia AIDS Coalition (IAC) percaya bahwa keterlibatan komunitas terdampak HIV, terutama orang yang hidup dengan HIV serta populasi kunci memegang peranan penting yang dapat mendongkrak keberhasilan upaya pengendalian HIV nasional. Untuk itu, sejak awal berdirinya IAC telah bekerja dengan fokus utama untuk memenuhi hak orang yang hidup dengan HIV serta kelompok terdampak HIV lainnya, terutama hak atas akses kesehatan, serta mengupayakan keterlibatan bermakna komunitas dalam perumusan program serta monitoring atas implementasinya.

Studi yang berjudul "Positioning Layanan Komunitas pada Program Pengendalian HIV dalam Kerangka Sistem Kesehatan Nasional (SKN)" ini kita lakukan untuk dapat melihat secara detil dan mendalam posisi komunitas terdampak dalam mendukung program pengendalian HIV nasional yang harapannya dapat mendorong integrasi layanan yang disediakan komunitas ke dalam SKN.

Studi ini dapat terlaksana berkat kerja sama baik antara IAC dengan tim peneliti dengan dukungan dari USAID lewat proyek LINKAGES, serta para ahli dan responden yang menjadi informan dalam kajian ini. IAC berharap kajian ini dapat menguatkan posisi komunitas dalam peran-peran baik strategis maupun implementatif serta monitoring dan evaluasi sehingga dapat mendukung peningkatan program HIV nasional.

Mewakili Indonesia AIDS Coalition, saya mengucapkan banyak terima kasih bagi para pihak yang terlibat dalam pelaksanaan dan penyusunan laporan studi ini, semoga laporan studi ini dapat bermanfaat bagi kita semua.

Aditya Wardhana

Direktur Eksekutif IAC 


\section{Daftar Isi}

Kata Pengantar i

Daftar Isi ii

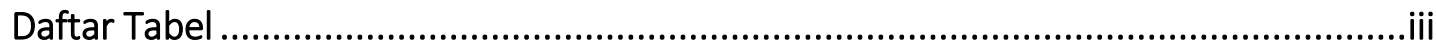

Daftar Gambar ..........................................................................................................

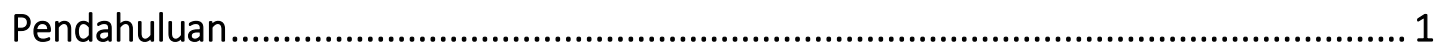

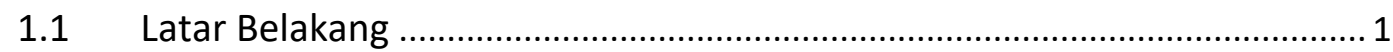

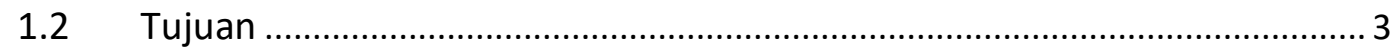

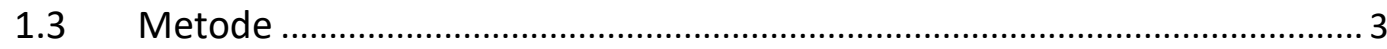

Kajian Literatur Layanan Komunitas Dalam Pengendalian HIV ................................... 6

2.1 Deskripsi dan Tujuan Kajian Literatur...................................................... 6

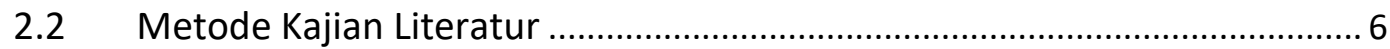

2.2.1 Pencarian dan Pemilihan Artikel ............................................................. 6

2.2.2 Skrining Judul dan Ringkasan Singkat (Abstract)................................. 7

2.2.3 Penilaian Eligibilitas dan Pemetaan ....................................................... 7

2.2.4 Sintesa Literatur Menggunakan Pendekatan Scoping Review ................... 8

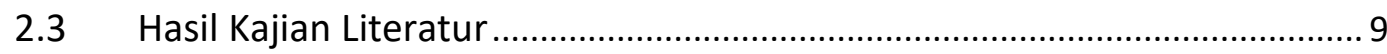

2.3.1 PK1. Bagaimanakah Metode Pelibatan Komunitas Dalam Pengendalian HIV Yang Telah Dilakukan di Berbagai Negara? 11

2.3.2 Pk2. Apakah Kelebihan Dan Kelemahan Dari Metode Pelibatan Komunitas Yang Telah Diterapkan Tersebut?

2.3.3 Pk3. Bagaimanakah Integrasi Pelibatan Komunitas Untuk Program HIV Dalam Kerangka SKN? ................................................................ 25

Analisis Dokumen Kebijakan Pengendalian HIV .................................................... 29

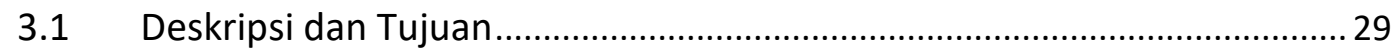

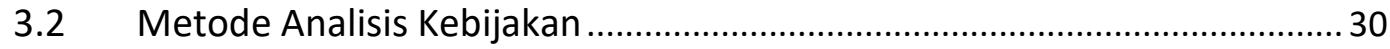

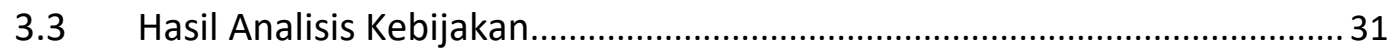

3.3.1 Potensi Hambatan Hukum ............................................................... 31

3.3.2 Penilaian Kinerja SKN Dalam Pengendalian HIV di Indonesia .................. 37

3.3.3 Kebijakan Desentralisasi dan Perannya Dalam Upaya Pengendalian HIV Serta Positioning Layanan Komunitas ..................................................... 40

3.4 Identifikasi Positioning Layanan Komunitas Terkait Pengendalian HIV ..... 43

Survei Delphi Positioning Layanan Komunitas dalam SKN (Siklus 1) .......................... 54

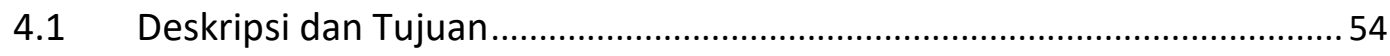

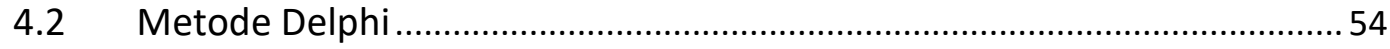

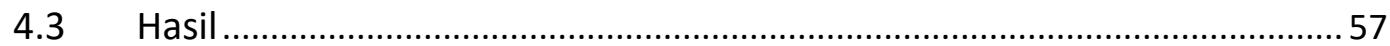


4.3.1 Persetujuan Model Pada Survei Delphi Tahap 1 57

4.3.2 Revisi Model Penempatan Komunitas Dalam Survei Delphi Tahap 2 ....... 59

4.3.3 Tingkat Persetujuan Terhadap Revisi Model Penempatan Komunitas..... 60

4.3.4 Masukan Mengenai Kegiatan ............................................................. 61

4.3.5 Pembahasan dan Rekomendasi Model ................................................. 64

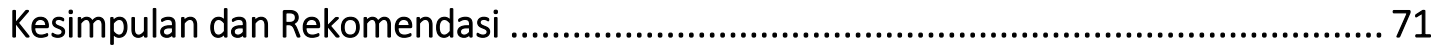

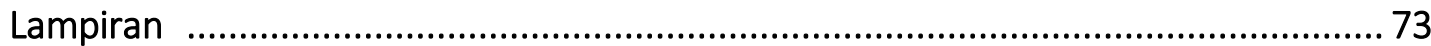

6.1 Daftar Artikel Yang Digunakan Dalam Kaji Literatur.................................... 73

6.2 Daftar Peraturan Perundangan Terkait Pencegahan HIV ............................. 76

6.3 Daftar Peraturan Perundangan terkait Upaya Perawatan, Dukungan, dan Pengobatan HIV 77

6.4 Formulir Pengumpulan Data Survei Delphi .................................................. 79

Daftar Pustaka 86

\section{Daftar Tabel}

Tabel 1. Kata Kunci Pencarian Literatur Secara Sistematik 6

Tabel 2. Rangkuman Peran Komunitas dalam Fungsi Layanan HIV 10

Tabel 3. Dokumen/Kebijakan/Strategi terkait Komponen Sistem Kesehatan Nasional dan Peran/Posisi Komunitas 46

Tabel 4. Peran Komunitas dalam Fungsi Layanan HIV/AIDS .55

Tabel 5. Tingkat Continuum of Integration untuk Layanan HIV. .55

Tabel 6. Kesetujuan Responden Mengenai Kegiatan-Kegiatan Partisipasi Komunitas dalam Layanan HIV.

Tabel 7. Kesetujuan Responden mengenai Aturan Hukum yang Mengatur SDM

Komunitas dalam Layanan terkait HIV $(n=41)$.

Tabel 8. Model Akhir Partisipasi Komunitas dalam SKN menurut Masukan Responden dalam Pengumpulan Data Delphi Siklus I dan II

\section{Daftar Gambar}

Gambar 1. Sistematika Studi 4

Gambar 2. Kerangka Konsep Positioning Layanan HIV Komunitas Dalam Sistem Kesehatan Nasional 5

Gambar 3. Prisma-Flow Sistematic Literature Review 9 Gambar 4. Ilustrasi Alur Metode Delphi. .55 


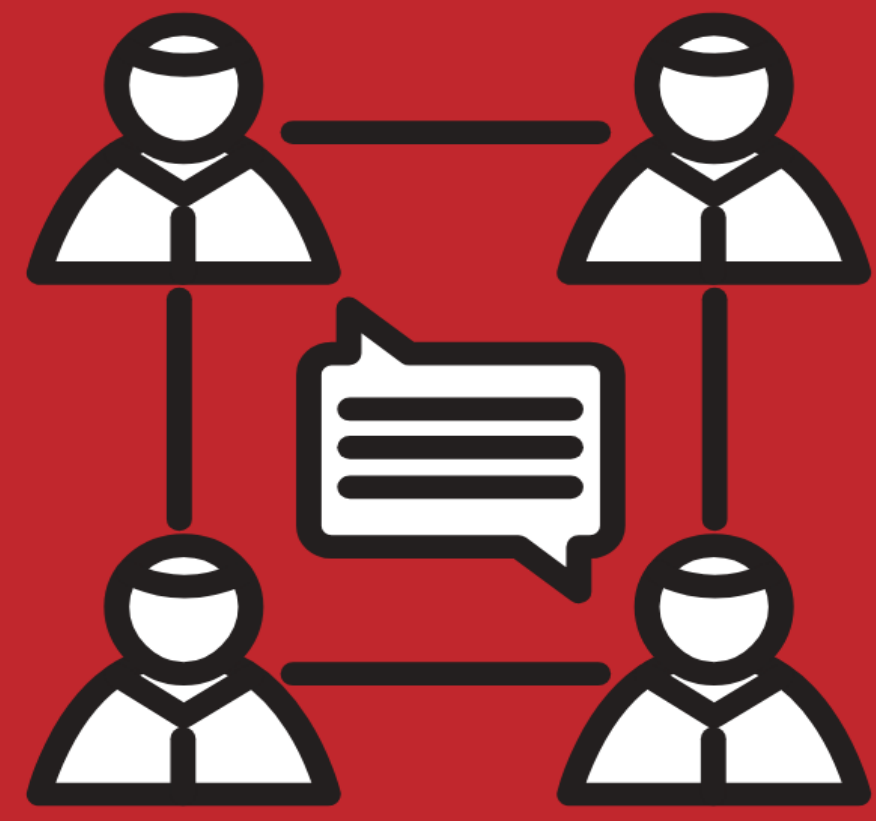

\section{Pendahuluan}

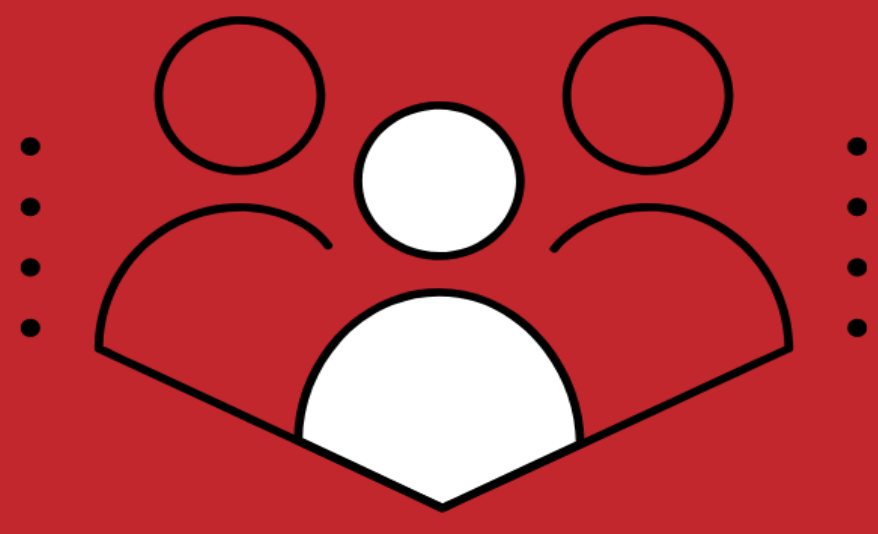




\section{Pendahuluan}

\subsection{Latar Belakang}

Sistem kesehatan bertujuan untuk menghasilkan pelayanan kesehatan yang bermutu, berkeadilan dan dapat memenuhi kebutuhan masyarakat termasuk kelompok marjinal dan yang memiliki risiko tinggi masalah kesehatan. ${ }^{1}$ Di Indonesia sendiri, sistem kesehatan nasional (SKN) didefinisikan sebagai bentuk dan cara penyelenggaraan pembangunan kesehatan yang memadukan berbagai upaya bangsa Indonesia dalam satu derap langkah guna menjamin tercapainya tujuan pembangunan kesehatan dalam kerangka mewujudkan kesejahteraan rakyat. Dalam definisi tersebut ditekankan upaya memadukan berbagai upaya bangsa yang diterjemahkan ke dalam pilar sistem kesehatan. Pilar pemberdayaan masyarakat merupakan salah satu pilar penting dari SKN Indonesia selain upaya kesehatan; penelitian dan pengembangan kesehatan; pembiayaan kesehatan; sumber daya manusia kesehatan; sediaan farmasi, alat kesehatan, dan makanan; manajemen informasi dan regulasi kesehatan. ${ }^{2}$

Pemberdayaan masyarakat dalam pembangunan kesehatan di Indonesia telah tercantum dalam SKN, dimana secara lebih rinci diatur dalam Peraturan Menteri Kesehatan (PMK) Nomor 84 Tahun 2015 tentang Pedoman Pengembangan Peran Serta Organisasi Kemasyarakatan Bidang Kesehatan, dan PMK Nomor 8 Tahun 2019 tentang Pemberdayaan Masyarakat Bidang Kesehatan. Secara umum, peran masyarakat dan organisasi kemasyarakatan dalam SKN meliputi perencanaan dan penetapan prioritas; pelaksanaan program promosi kesehatan dan upaya pencegahan; pemantauan, evaluasi, dan peningkatan kualitas; dan advokasi. Kerangka kebijakan yang sudah ada juga menyoroti bagaimana berbagai komponen masyarakat telah dan dapat dilibatkan untuk mendukung peran aktor formal dalam sistem kesehatan sehingga perawatan kesehatan lebih responsif terhadap konteks lokal dan menjangkau lebih banyak populasi. Walaupun demikian peran organisasi kemasyarakatan, masyarakat secara umum dan komunitas yang paling terdampak oleh suatu masalah kesehatan masih belum menjadi bagian integral dari pelayanan kesehatan dibanyak negara termasuk di Indonesia. Saat ini, data tentang efektivitas pendekatan berbasis masyarakat sebagian besar berasal dari proyek-proyek yang didanai mitra pembangunan internasional yang dilaksanakan melalui program vertikal yang paralel dengan program dalam SKN. ${ }^{3}$

Penguatan sistem kesehatan (health system strengthening - HSS) secara umum sekarang diakui sebagai komponen penting untuk meningkatkan kesehatan global. ${ }^{4}$ Salah satu aspek penting dari HSS yang diidentifikasi membutuhkan penjelasan yang lebih kuat adalah peran komunitas, masyarakat sipil, dan organisasi berbasis komunitas.5,6 Kebutuhan akan integrasi peran masyarakat secara umum dan komunitas yang paling terdampak suatu masalah kesehatan dalam perencanaan, pelayanan, dan evaluasi suatu layanan kesehatan menjadi semakin nyata dengan adanya wabah penyakit menular baru-baru ini. ${ }^{7,8}$ Dalam konteks upaya pengendalian HIV di Indonesia, komunitas sering didefinisikan sebagai kelompok 
masyarakat yang paling terdampak atau sekelompok individu dengan beberapa karakteristik spasial, budaya, bahasa, dan organisasi yang serupa, dengan beberapa kapasitas untuk tindakan kolektif.

Target secara global 90-90-90 dari The Joint United Nations Programme on HIV/AIDS (UNAIDS) untuk memastikan bahwa 90\% orang yang hidup dengan HIV (ODHIV) mengetahui status mereka, 90\% orang dengan infeksi HIV yang didiagnosis menerima terapi antiretroviral (ART)dan 90\% dari mereka yang dalam pengobatan ART memiliki jumlah virus yang tersupresi ${ }^{9}$ telah diadopsi oleh banyak negara termasuk Indonesia. Mencapai target ini membutuhkan peningkatan substansial dalam cakupan layanan yang sulit dicapai melalui layanan HIV berbasis fasilitas tradisional. Pendekatan berbasis komunitas telah terbukti meningkatkan cakupan tes HIV, meningkatkan proporsi orang testing HIV untuk pertama kalinya, dan menemukan ODHIV lebih awal dalam perjalanan infeksi HIV, 10,11,12 serta meningkatkan akses kepada perawatan, dukungan dan pengobatan. ${ }^{13,14,15}$

Komunitas terutama dari kelompok masyarakat yang paling terdampak atau populasi kunci memiliki peran penting dalam mendorong kebijakan dan strategi pengendalian HIV. Lebih lanjut, peran penting komunitas terlihat jelas dalam upaya pencapaian target 90-90-90, diantaranya keterlibatan aktif dalam proses penjangkauan populasi kunci untuk meningkatkan kemampuan mencegah infeksi HIV, melakukan tes HIV dan memulai pengobatan jika positif. Selain itu, peran penting lainnya untuk memastikan pasien ODHIV patuh dalam terapi antiretroviral (ART) serta bagaimana komunitas melakukan penelusuran terhadap kasus ODHIV yang tidak melanjutkan ART di layanan kesehatan. Laporan Survei Terpadu Biologi dan Perilaku (STPB) pada populasi kunci HIV tahun 2018 menunjukan persentase ODHIV yang mengetahui status HIV nya dua hingga 4 kali lebih tinggi di kabupaten/kota dimana layanan komunitas dengan dukungan dana Mitra Pembangunan Internasional (MPI) dilakukan. ${ }^{16}$

Meskipun terbukti efektif, pendanaan MPI untuk layanan komunitas secara global maupun di Indonesia, cenderung mendatar atau menurun, ${ }^{17}$ dengan seruan untuk mengintegrasikan layanan HIV oleh komunitas ke dalam sistem kesehatan nasional sebagai strategi untuk mengurangi stigma dan meningkatkan berkelanjutan layanan HIV. ${ }^{18,19}$ Namun, integrasi mungkin tidak semudah kelihatannya; tinjauan literatur tentang integrasi layanan kesehatan seksual ke dalam layanan kesehatan primer mengungkapkan sejumlah tantangan dari kebijakan pemerintah, koordinasi, logistik, sumber daya manusia (SDM), pelatihan, pengawasan dan pembiayaan. ${ }^{20,21}$ Pada saat yang sama dengan penurunan dana MPI di Indonesia, dua perubahan dalam penyediaan layanan kesehatan di Indonesia menawarkan jendela peluang untuk integrasi. Pertama, standar pelayanan minimal bidang kesehatan (termasuk layanan terkait program pengendalian HIV) di Indonesia telah didesentralisasikan dari pemerintah pusat ke 514 pemerintah kabupaten/kota dengan keputusan seputar prioritas penyediaan layanan sekarang sedang ditentukan dan didanai di tingkat kabupaten/kota. Dan kedua, adanya rencana reformasi sistem kesehatan nasional yang akan berfokus pada 8 area yaitu pendidikan dan penempatan tenaga kesehatan; penguatan puskesmas; peningkatan kualitas rumah sakit dan pelayanan kesehatan daerah terpencil, perbatasan dan kepulauan; kemandirian farmasi dan alat kesehatan; ketahanan kesehatan; pengendalian

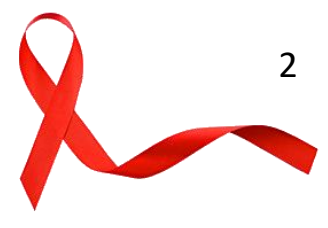


penyakit dan imunisasi; pembiayaan kesehatan; serta teknologi informasi; dan pemberdayaan masyarakat.

Berdasarkan uraian di atas, dilakukan studi terhadap penentuan posisi (positioning) layanan komunitas ke dalam sistem kesehatan untuk pengendalian HIV sesuai dengan kerangka SKN dalam rangka percepatan pencapaian nasional terhadap target 90-90-90 dan mengakhiri epidemi HIV pada tahun 2030.

\subsection{Tujuan}

Tujuan umum dari studi ini adalah untuk memberikan rekomendasi analitik dan implementatif dalam positioning layanan komunitas dalam program pengendalian HIV di Indonesia. Rekomendasi tersebut kemudian dapat dijadikan bahan advokasi kepada pemangku kebijakan terkait. Sedangkan tujuan khusus dari studi ini meliputi:

- Melakukan kajian literatur secara sistematis tentang jenis, status integrasinya dengan SKN, dan pembelajaran negara lain dari layanan komunitas dalam program pengendalian HIV

- Analisis dokumen kebijakan terkait program pengendalian HIV dan layanan komunitas

- Mengidentifikasi tingkat kepentingan dan dukungan layanan komunitas dalam SKN baik dari segi pengarusutamaan peran terhadap layanan kesehatan maupun keberlanjutan pembiayaan

\subsection{Metode}

Studi ini dilakukan dengan menggunakan 2 metode yaitu:

- Metode kualitatif berupa analisis naratif terhadap literatur berbahasa Inggris yang ditemukan dan dipilih dari beberapa tahapan pencarian secara sistematis di PubMed dan Google Scholar serta dokumen kebijakan terkait program pengendalian HIV di Indonesia.

- Metode kuantitatif dengan surevi Delphi 2 tahap untuk mengeksplorasi persepsi para pelaku di tingkat makro (disebut sebagai tingkat pembuat kebijakan dan akademisi), tingkat meso (pengelola program) dan tingkat mikro (pengelola dan penyedia layanan komunitas). Kerangka makro-meso-mikro ini telah digunakan dalam studi implementasi kebijakan dan mengacu pada teori yang ada bahwa peserta di setiap tingkat 'membingkai' pemahaman mereka secara berbeda.

Langkah-langkah dari setiap metode dalam studi ini secara lebih terperinci akan diuraikan bersama dengan hasilnya pada bab berikutnya tentang kajian literatur, analisis kebijakan dan survei Delphi. Secara umum, sistematika studi dimulai dengan melakukan kajian literatur secara sistematis untuk mengidentifikasi bentuk bentuk layanan yang dapat diberikan oleh komunitas dan terbukti efektif. Selain itu kajian literatur menghasilkan tingkat integrasi layanan komunitas di dalam sistem kesehatan. Hasil dari kajian literatur bersama dengan analisis dokumen kebijakan kemudian digunakan untuk mengembangkan jenis layanan dan tingkat integrasi yang dimintakan pendapatnya kepada responden survei Delphi. 
Berdasarkan hasil survei Delphi dua putaran ini kemudian dikembangkan positioning model layanan komunitas untuk program pengendalian HIV dalam kerangka SKN di Indonesia.

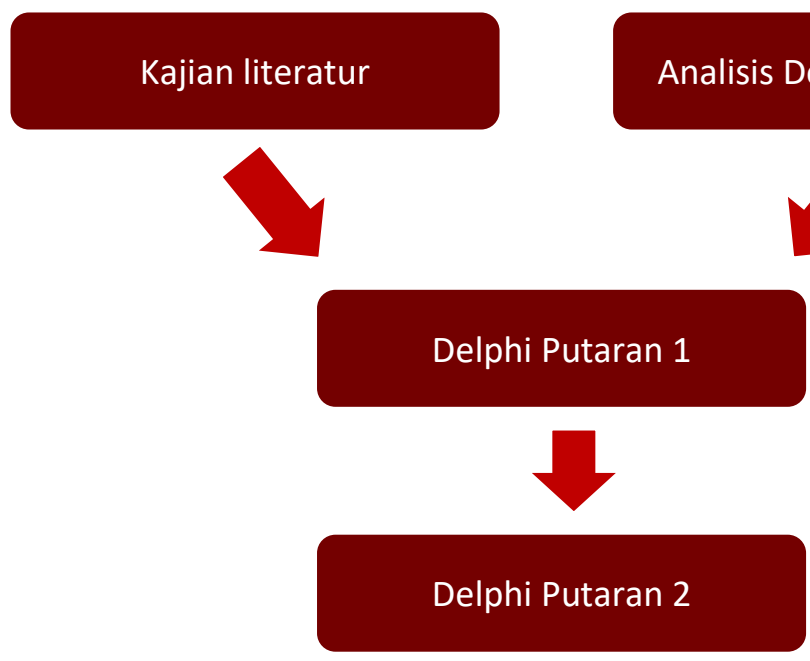

Gambar 1. Sistematika Studi

Studi Kerangka kerja kajian yang diusulkan secara umum menggunakan pendekatan mix-methods dengan menggunakan tiga kerangka kerja utama yaitu SKN berdasarkan Perpres (PerPres) Nomor 72 tahun 2012, Chronic Disease Care models22,23 dengan diferensiasi fungsi layanan serta konsep continuum of integration. ${ }^{24,25}$ Berikut ini adalah penggambaran kerangka kerja kajian yang akan menjadi rujukan dalan analisis baik literatur, dokumen kebijakan, dan survei Delphi. 


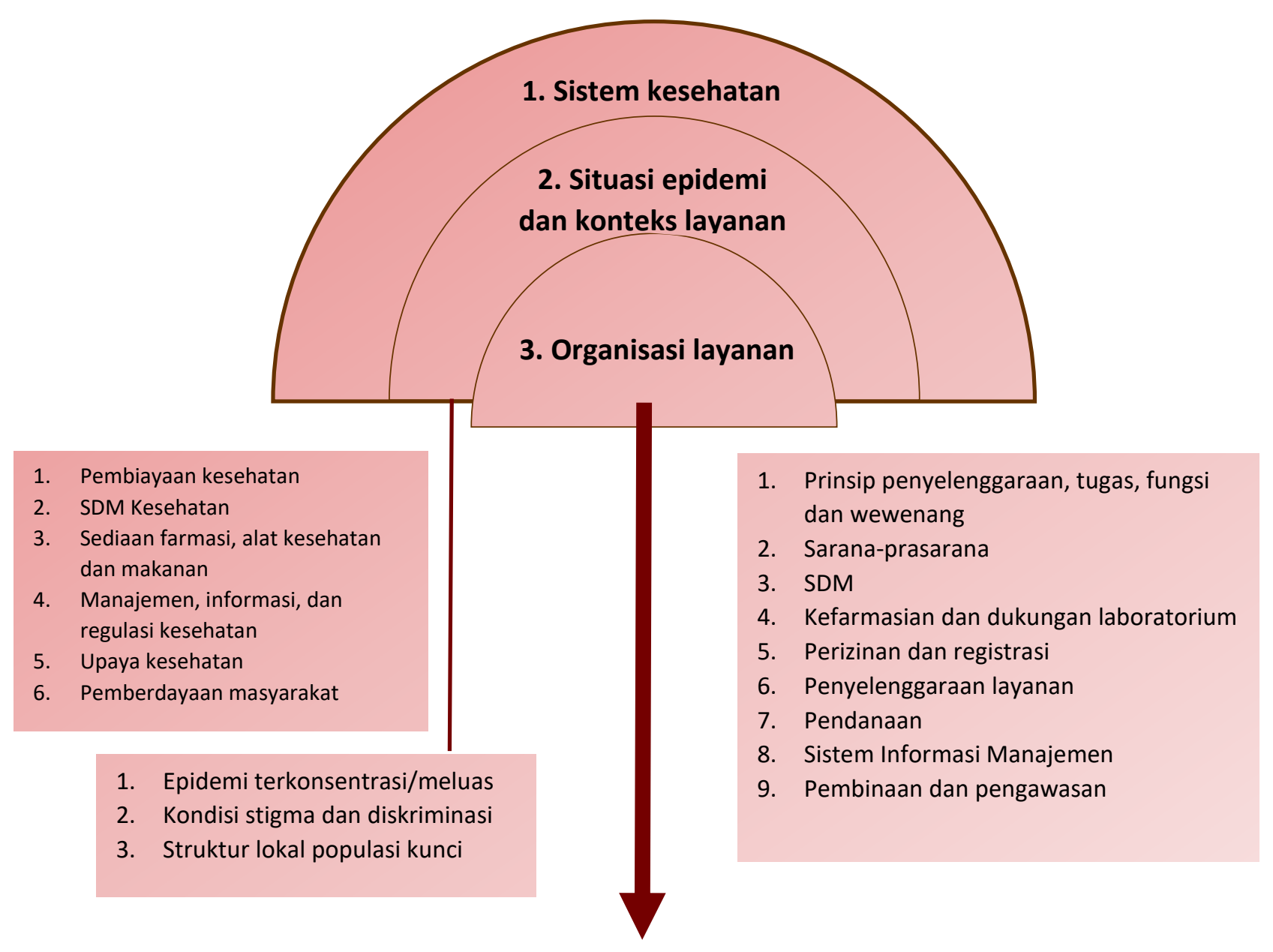

\begin{tabular}{|c|c|c|c|}
\hline \multirow[t]{2}{*}{ Fungsi layanan HIV } & \multicolumn{3}{|c|}{ Continuum of integration* } \\
\hline & Co-ordinated & Co-located & Integrated \\
\hline \multicolumn{4}{|l|}{ 1. Pencegahan; layanan perubahan perilaku } \\
\hline \multicolumn{4}{|l|}{$\begin{array}{l}\text { 2. Diagnosis tepat dan cepat termasuk skrining } \\
\text { berbasis komunitas dan metode lainnya }\end{array}$} \\
\hline \multicolumn{4}{|l|}{$\begin{array}{l}\text { 3. Manajemen medis dan klinis termasuk } \\
\text { layanan dukungan diagnostik dan dukungan } \\
\text { memulai terapi }\end{array}$} \\
\hline \multicolumn{4}{|l|}{$\begin{array}{l}\text { 4. Dukungan pengobatan; retensi, manajemen } \\
\text { mandiri, dan dukungan peer }\end{array}$} \\
\hline $\begin{array}{l}\text { 5. Dukungan psikososial dalam konteks } \\
\text { lokal/kultural/religius }\end{array}$ & & & \\
\hline $\begin{array}{l}\text { 6. Komunikasi dan koordinasi antara organisasi } \\
\text { penyedia layanan, pasien dan } \\
\text { komunitas/organisasi komunitas }\end{array}$ & & & \\
\hline
\end{tabular}

Gambar 2. Kerangka Konsep Positioning Layanan HIV Komunitas Dalam Sistem Kesehatan Nasional 


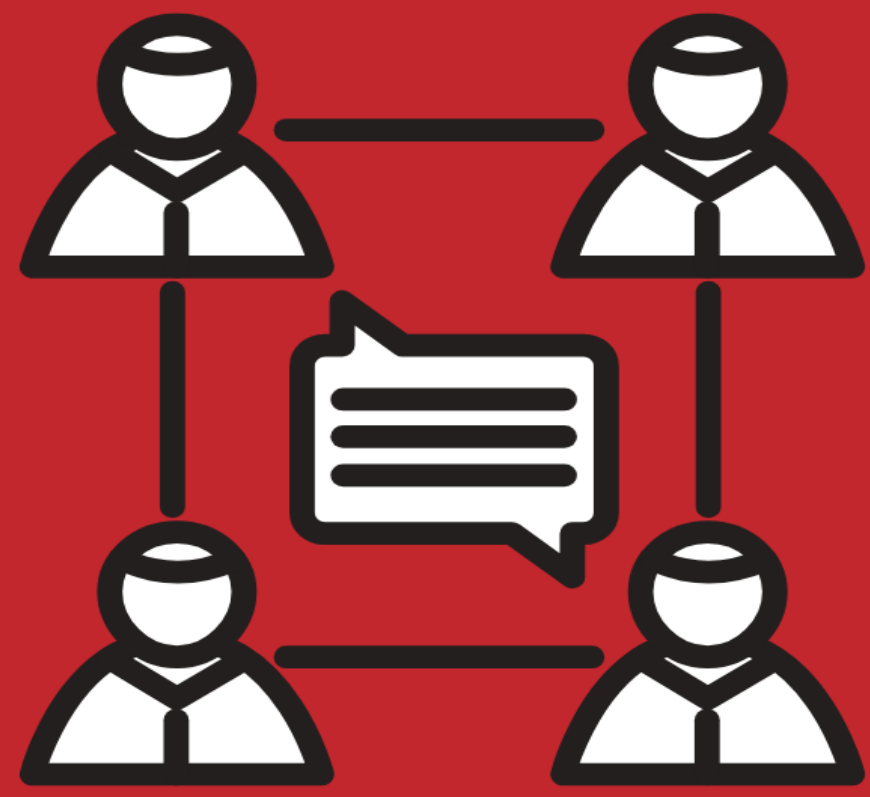

Kajian Literatur Layanan Komunitas dalam Pengendalian HIV

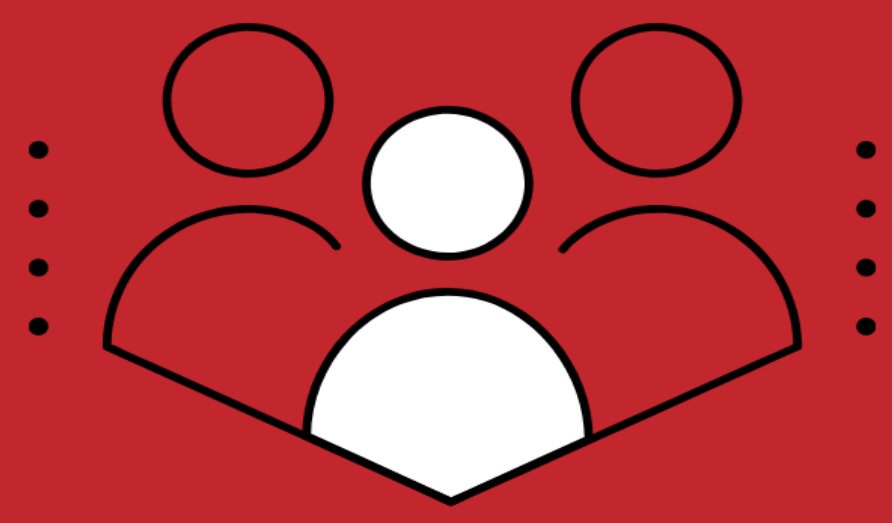




\section{Kajian Literatur Layanan Komunitas Dalam Pengendalian HIV}

\subsection{Deskripsi dan Tujuan Kajian Literatur}

Secara umum, tujuan dari kajian literatur ini adalah untuk mengidentifikasi bentuk keterlibatan aktif komunitas dalam layanan kesehatan terkait dan tingkat integrasinya dalam SKN, dengan tujuan spesifik antara lain sebagai berikut:

1. Mengidentifikasi layanan komunitas dalam kerangka SKN yang dapat berkontribusi dalam pencapaian target program pengendalian HIV

2. Mengkaji tingkat integrasi peran komunitas dalam sistem pelayanan kesehatan

3. Mengidentifikasi strategi yang dapat dilakukan untuk meningkatkan peran komunitas dan integrasinya dalam dalam pengendalian HIV

Lebih lanjut disusun tiga pertanyaan kajian yang digunakan sebagai rujukan dalam proses pencarian, pemilihan dan analisis literatur secara sistematis sebagai berikut:

1. PK1. Bagaimanakah model layanan komunitas dalam pengendalian HIV yang telah dilakukan di berbagai negara?

2. PK2. Apakah kelebihan dan kelemahan dari metode layanan komunitas yang telah diterapkan tersebut?

3. PK3. Bagaimanakah integrasi layanan komunitas dalam program HIV dengan kerangka Sistem Kesehatan Nasional.

\subsection{Metode Kajian Literatur}

\subsubsection{Pencarian dan Pemilihan Artikel}

Kajian literatur dilakukan terhadap sumber artikel ilmiah di jurnal ilmiah internasional dan website organisasi yang mempromosikan layanan komunitas dalam pengendalian HIV di dunia, maupun grey literature berupa laporan kegiatan pemberdayaan komunitas dari berbagai organisasi internasional, regulasi, laporan evaluasi, dan laporan penelitian yang tidak dipublikasi di jurnal ilmiah. Pencarian literatur dilakukan melalui database yang tersedia secara daring dengan menggunakan mesin pencari Pubmed dan Google scholar. Kata kunci menggunakan logika Boolean yaitu "And", 'OR”, "Not".

Tabel 1. Kata Kunci Pencarian Literatur Secara Sistematik

\begin{tabular}{|l|l|l|l|l|l|}
\hline \multicolumn{1}{|c|}{ Keywords } & \multicolumn{1}{|c|}{ AND } & \multicolumn{1}{c|}{ AND } & \multicolumn{1}{c|}{ AND } & \multicolumn{1}{c|}{ AND } \\
\hline OR & Community & Involvement & HIV & Intervention & "Health System" \\
\hline Society & Engagement & AIDS & Prevention & \\
\hline People & Participation & & Program & \\
\hline & Contribution & & Management & \\
\hline & Collaboration & & Treatment & \\
\hline & & & Therapy & \\
\hline & & & Promotion & \\
\hline
\end{tabular}

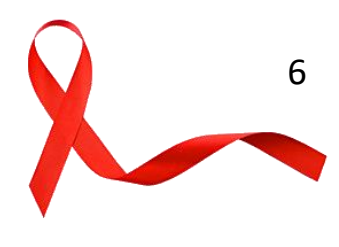


Artikel yang ditemukan kemudian dipindahkan ke aplikasi EndNote/Mendeley untuk kemudian diidentifikasi dan mencegah adanya duplikasi. Setelah memastikan semua duplikasi telah dihapus, maka dilanjutkan dengan proses pemilihan artikel yang sesuai dengan kriteria sebagai berikut:

1. Artikel diterbitkan setelah tahun 2010

2. Artikel memiliki rancangan studi observasi dan eksperimen dengan menggunakan pengumpulan data primer yaitu cross-sectional, case-control, cohort, randomized control and trial, survey serta penelitian kualitatif dengan metode wawancara maupun diskusi kelompok terfokus.

3. Artikel memuat metode pelibatan komunitas dalam program pengendalian HIV di suatu negara yang dalam kerangka sistem kesehatan nasional.

4. Artikel (abstrak dan full text) ditulis dalam Bahasa Inggris.

5. Artikel (full text) dapat diunduh.

\subsubsection{Skrining Judul dan Ringkasan Singkat (Abstract)}

Hasil pencarian artikel menggunakan keywords pada search engine (PubMed dan Google Scholar) kemudian diskrining untuk menemukan judul dan atau ringkasan singkat yang tepat dengan kriteria sebagai berikut:

> Menuliskan pelibatan komunitas (Community Engagement or Community involvement or people involvement or group-based intervention or group support).

> Menuliskan peran komunitas dalam program HIV yaitu preventif (promotif, penapisan/testing), kuratif (pengobatan, perawatan dan dukungan), rehabilitasi dan penelitian.

Artikel yang memenuhi kriteria kemudian di download (full text) dan dipetakan menurut tiga pertanyaan penilaian kualitas literatur diatas.

\subsubsection{Penilaian Eligibilitas dan Pemetaan}

Seluruh artikel yang memenuhi kriteria dan lolos dalam tahapan skrining judul dan abstrak kemudian memasuki tahapan penilaian eligibilitas terhadap keseluruhan isi artikel dengan membaca secara lebih teliti konteks pelibatan komunitas dalam program pengendalian HIV dan integrasinya dengan SKN secara lebih mendalam. Artikel yang kemudian masuk dalam proses analisis haruslah mampu menjawab pertanyaan kajian dan memenuhi kriteria:

> Menyebutkan secara jelas metode/teknik pelibatan komunitas dalam program HIV (promotif, testing, kuratif, rehabilitatif maupun penelitian)

> Menyebutkan kekurangan maupun kelebihan dari metode pelibatan komunitas yang telah diterapkan tersebut. Poin ini merupakan opsional, namun harus dicari dengan teliti apakah pelibatan komunitas tersebut memungkinkan untuk dijalankan, apakah mampu mencapai hasil yang ditargetkan dan kelemahan apa saja yang kemudian menjadi pertimbangannya.

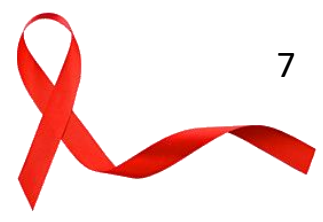


> Menyebutkan integrasi layanan komunitas dalam program pengendalian HIV dengan kerangka SKN suatu negara. Poin ini merupakan opsional karena tidak semua layanan komunitas masuk dalam SKN ataupun menjadi program resmi dari suatu negara.

Artikel yang memenuhi kriteria eligibilitas akan diringkas kedalam sebuah tabel dengan tajuk sebagaimana daftar dibawah ini. Selain itu juga ditentukan apakah pelibatan komunitas dalam program HIV masuk dalam intervensi preventif (promotif, skrining/testing), kuratif, rehabilitatif ataupun penelitian.

$>$ Judul

$>$ Penulis

> Metode Penelitian

> Metode/teknik pelibatan komunitas dalam pengendalian HIV

$>$ Kelebihan Metode

$>$ Kekurangan Metode

$>$ Integrasi dalam sistem kesehatan

> Pelibatan komunitas dalam pengendalian HIV (promotif, preventif, testing, kuratif atau penelitian)

\subsubsection{Sintesa Literatur Menggunakan Pendekatan Scoping Review}

Semua artikel yang memenuhi persyaratan dianalisis dengan menggunakan pendekatan scoping review yang akan menyajikan mekanisme pencarian dan ekstraksi informasi secara transparan tapi dalam analisis dokumennya berpusat pada upaya mengidentifikasi bukti ilmiah yang tersedia dan konsep serta definisi, sehingga sesuai dengan tujuan kajian. Metode analisis ini merupakan pendekatan untuk mensintesa temuan dari banyak penelitian. Metode ini juga digunakan untuk menjawab 3 pertanyaan kajian (PK) terkait pelibatan komunitas di dalam Program HIV dan integrasinya dalam SKN.

PK1. Bagaimanakah metode pelibatan komunitas dalam pengendalian HIV yang telah dilakukan di berbagai negara?

> Untuk menjawab ini maka digunakan hasil pemetaan artikel mengenai pelibatan komunitas dalam program HIV preventif (promotif, screening/testing), kuratif, rehabilitatif dan research.

> Masing-masing artikel dalam kelompok tersebut akan disintesis untuk menemukan summary dari findings terkait teknik pelibatan komunitas dalam 5 kelompok tersebut.

PK2. Apakah kelebihan dan kelemahan dari metode pelibatan komunitas yang telah diterapkan tersebut?

> Setiap teknik/metode pelibatan komunitas yang mencantumkan kelebihan dan kelemahan implementasinya akan disintesis sehingga akan didapatkan rangkumannya. Hal ini akan menjadi dasar pertimbangan dalam melibatkan komunitas dalam suatu program HIV.

PK3. Bagaimanakah integrasi pelibatan komunitas dalam program HIV dengan kerangka Sistem Kesehatan Nasional. 
> Artikel yang mencantumkan integrasi pelibatan komunitas dalam program HIV akan disintesis untuk menemukan hasil terkait bagaimana mekanisme pelibatan komunitas tersebut dalam program kesehatan nasional suatu negara.

\subsection{Hasil Kajian Literatur}

Hasil dari proses pencarian, pemilihan, skrining dan pemetaan artikel menemukan 80 artikel yang layak untuk dianalisis. Gambaran hasil disetiap tahapan pencarian, pemilihan, skrining dan pemetaan artikel dapat dilihat pada gambar dibawah.

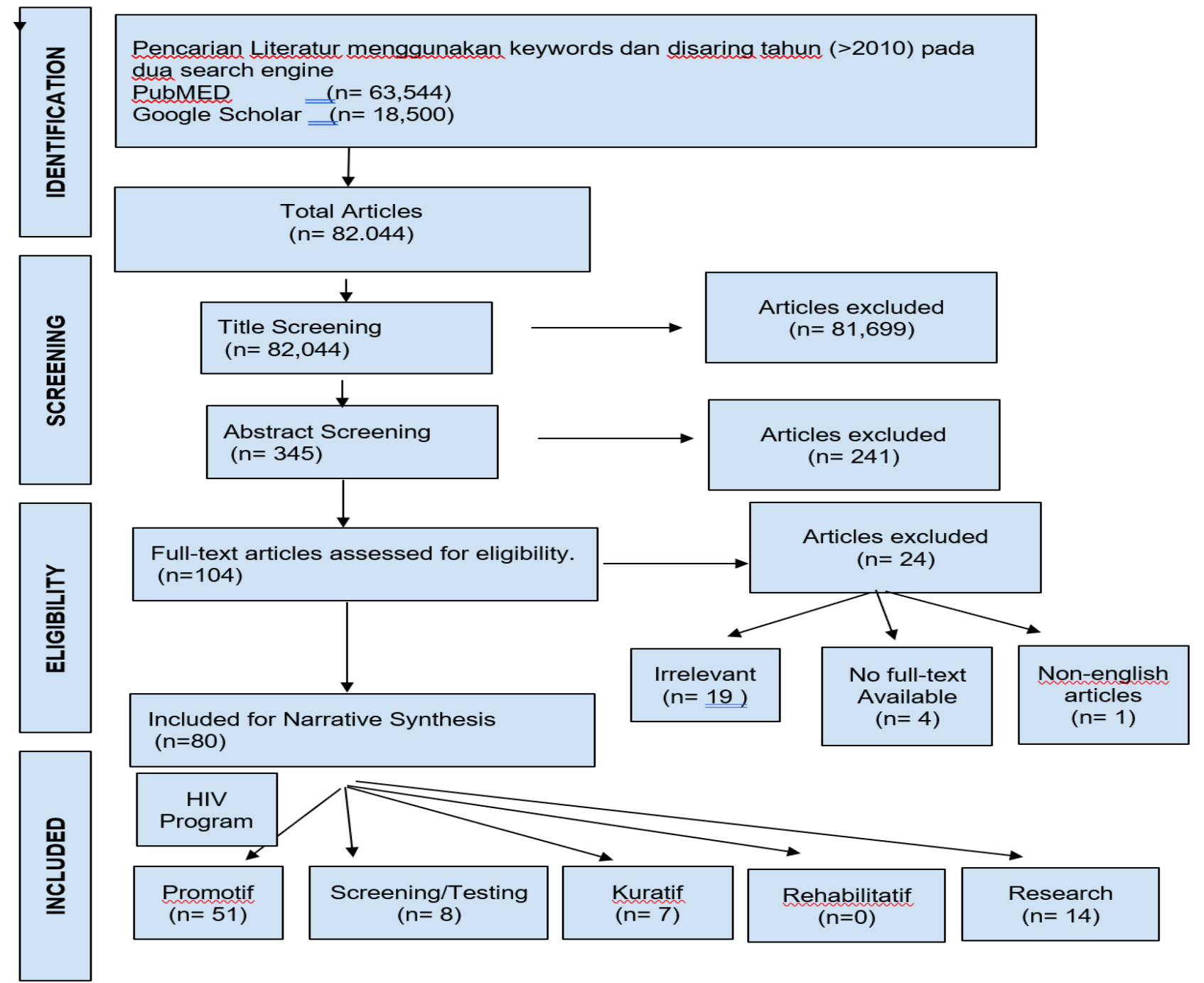

Gambar 3. Prisma-Flow Sistematic Literature Review 
Sedangkan ringkasan dari analisis artikel terpilih dapat dilihat pada tabel dibawah ini.

Tabel 2. Rangkuman Peran Komunitas dalam Fungsi Layanan HIV

\begin{tabular}{|c|c|}
\hline Fungsi layanan HIV & Kegiatan yang didapatkan dari kajian literatur \\
\hline $\begin{array}{l}\text { 1. Pencegahan; layanan } \\
\text { perubahan perilaku }\end{array}$ & $\begin{array}{l}\text { - Kelompok dukungan sebaya (KDS ) dengan memberikan intervensi } \\
\text { berupa modul edukasi berkaitan dengan HIV dan perubahan } \\
\text { perilaku. } \\
\text { - Kampanye/konseling melalui radio, aplikasi, web, internet maupun } \\
\text { sosial media e.g Telehealth apps, Positive Links Apps, The THT Show, } \\
\text { kampanye sosial merekrut populasi kunci untuk bergabung kedalam } \\
\text { KDS melalui Facebook, Grinder, dan Adam4Adam. } \\
\text { - Mobilisasi komunitas seperti proyek Proyecto Orgullo, CM for } \\
\text { Treatments as Prevention (TasP), mobilisasi dengan mengadakan } \\
\text { lokakarya dan edukasi perubahan perilaku, pelibatan komunitas dan } \\
\text { pemangku kepentingan } \\
\text { - Program navigator pasien ; untuk mempromosikan perawatan bagi } \\
\text { ODHIV dan memastikan ODHIV tidak kehilangan akses ke ART }\end{array}$ \\
\hline $\begin{array}{l}\text { 2. Diagnosis tepat dan cepat } \\
\text { termasuk skrining berbasis } \\
\text { komunitas dan metode } \\
\text { lainnya }\end{array}$ & $\begin{array}{l}\text { - } \text { Skrining tes mandiri yang dapat dilakukan sendiri oleh ODHIV di } \\
\text { - } \text { - Skmunitas } \\
\text { - } \text { Rapid test HIV di layanan kesehatan berbasis komunitas } \\
\text { - Layanan notifikasi pasangan }\end{array}$ \\
\hline $\begin{array}{l}\text { 3. Manajemen medis dan } \\
\text { klinis termasuk layanan } \\
\text { dukungan diagnostik dan } \\
\text { dukungan memulai terapi }\end{array}$ & $\begin{array}{l}\text { - Dukungan memulai terapi antara lain melalui model konselor } \\
\text { komunitas dan KDS } \\
\text { - Integrasi testing penyakit tidak menular dengan testing HIV } \\
\text { menggunakan tes cepat HIV }\end{array}$ \\
\hline $\begin{array}{l}\text { 4. Dukungan pengobatan; } \\
\text { retensi, manajemen } \\
\text { mandiri, dan dukungan } \\
\text { peer }\end{array}$ & $\begin{array}{l}\text { - Distribusi ART berbasis Komunitas } \\
\text { - } \text { Distribusi ART dengan Prinsip Manajemen Mandiri melalui Kelompok } \\
\text { - Dukungan Retensi Pengobatan melalui Kelompok Kepatuhan Minum } \\
\text { Obat } \\
\text { - Dukungan Komunitas terhadap Program HIV melalui Organisasi } \\
\text { Komunitas }\end{array}$ \\
\hline $\begin{array}{l}\text { 5. Dukungan psikososial } \\
\text { dalam konteks } \\
\text { lokal/kultural/religius }\end{array}$ & $\begin{array}{l}\text { - Pelibatan komunitas melalui organisasi keagamaan } \\
\text { - Barber-shops based Intervention } \\
\text { - Dukungan sebaya untuk ART (treatment partnerl) }\end{array}$ \\
\hline $\begin{array}{l}\text { 6omunikasi dan koordinasi } \\
\text { antar organisasi penyedia } \\
\text { layanan, pasien dan } \\
\text { komunitas }\end{array}$ & $\begin{array}{l}\text { - Komunikasi dan koordinasi antara layanan kesehatan dengan pasien } \\
\text { - Keterlibatan komunita melalui organisasi komunitas dan } \\
\text { pemimpinnya }\end{array}$ \\
\hline $\begin{array}{l}\text { 7. Pelibatan Komunitas dalam } \\
\text { penelitian HIV }\end{array}$ & $\begin{array}{l}\text { - Crowdsourcing; Penelitian yang menggunakan metode ini antara lain } \\
\text { Percobaan Klinis (Clinical trials) dan HIV Cure Research } \\
\text { - Community Based Participatory Research (CBPR); Penelitian yang } \\
\text { menggunakan metode ini antara lain Pengembangan PrEP Tool Kit } \\
\text { dan Pengembangan Instrumen Status Kesehatan Disabilitas }\end{array}$ \\
\hline
\end{tabular}


Hasil analisis artikel terpilih yang dikelompokan menurut pertanyaan kajian (PK) secara lebih detil dituliskan dalam sub-bagian hasil berikut ini.

\subsubsection{PK1. Bagaimanakah Metode Pelibatan Komunitas Dalam Pengendalian HIV Yang Telah Dilakukan di Berbagai Negara?}

\section{Pencegahan; Layanan Komunikasi Perubahan Perilaku}

Pelibatan komunitas dalam upaya promotif pengendalian HIV sudah cukup banyak ditemui di berbagai negara. Salah satu model yang paling sering dilakukan dalam upaya promotif preventif juga dan melibatkan komunitas adalah model penyediaan edukasi, konseling maupun layanan perubahan perilaku.

a. Edukasi Melalui Kelompok Sebaya (Peer-Group)

Pelibatan kelompok sebaya dalam upaya promotif dan preventif HIV sudah umum dilakukan terutama untuk menyasar kelompok-kelompok yang termarjinalkan. Cukup banyak penelitian menemukan bahwa peran penting peer-group. Salah satu intervensi peer group yang diberi nama "Connect with Us" (CWU) merupakan intervensi berbasis komunitas dengan membentuk kelompok kecil yang dirancang untuk mengurangi efek negatif stigma dan marginalisasi di antara LSL kulit hitam. Dalam metode ini, dilakukan pemilihan Duta CWU yang berfungsi sebagai fasilitator dan panutan untuk memberikan edukasi dan informasi rujukan ke pelayanan HIV serta sumber daya yang mendukung untuk upaya pengurangan risiko. Terdapat beberapa sesi edukasi yang disampaikan diantaranya mengenai mengadopsi perilaku seks yang lebih aman, mencari tes HIV, mengungkapkan Status HIV untuk pasangan seksual, mencari pencegahan dan layanan medis seperti obat pencegah penularan infeksi bagi orang-orang yang berisiko tinggi tertular HIV atau pre-exposure prophylaxis (PrEP). ${ }^{26}$

Pendekatan lainnya yang digunakan untuk melibatkan komunitas melalui KDS yaitu melalui "She is Like a Sister to Me". Pada penelitian tersebut, komunitas dilibatkan melalui dukungan sebaya untuk memperkuat pentingnya kesehatan dan perawatan HIV dan memberikan dukungan timbal balik. Layanan yang menegaskan gender dan hubungan kepedulian merupakan dua karakteristik utama dari intervensi yang mengatasi hambatan individu dan struktural bagi Transgender Women of Color (TWOC) dalam perawatan HIV. ${ }^{27}$ Penelitian lain yang menggunakan pendekatan kelompok sebaya yaitu penelitian yang dilakukan pada 3 wilayah perkotaan di Amerika dengan memberikan 7 sesi pendidikan tatap muka selama 60 menit setiap 1-3 minggu tentang topik khusus yang meningkatkan perawatan dan pengobatan HIV. Selama periode yang sama, rekan dalam kelompok sebaya juga melakukan check-in mingguan melalui telepon atau pertemuan secara langsung yang berkisar antara 30 hingga 60 menit atau setiap 2 minggu hingga 4 bulan. Interaksi ini berfokus terutama pada pembangunan hubungan. Selain itu, rekan sejawat dilatih untuk memberikan pengingat janji yang dijadwalkan, dan untuk berdiskusi tentang kunjungan medis dan dukungan untuk perawatan. ${ }^{28}$ 
Intervensi dukungan sebaya berupa "health scout intervention" dilakukan pada komunitas di wilayah Rakai, Uganda melibatkan komunitas non-kesehatan dengan kriteria: individu yang menempuh pendidikan lebih dari 7 tahun, tidak buta huruf, dan harus mengetahui status HIV mereka. Intervensi ini ditujukan untuk mempromosikan informasi mengenai HIV, motivasi, dan keterampilan perilaku yang relevan untuk meningkatkan keterlibatan komunitas dalam pengobatan HIV dan layanan pencegahan. ${ }^{29}$

b. Pelibatan Komunitas Melalui Promosi Di Radio/Internet/Aplikasi/Web-Based

Beberapa studi menunjukkan bahwa pendekatan promosi dengan memanfaatkan teknologi maupun sosial media cukup banyak memberikan dampak dan efisien untuk dilakukan, terutama pada wilayah yang terpapar akses internet maupun radio. Studi dengan memanfaatkan fasilitas tersebut diantaranya melalui beberapa kanal seperti menggunakan satu saluran radio (The THT Show) yang khusus membahas topik mengenai HIV, aplikasi Telehealth yang mengkombinasikan pertemuan virtual melalui video call yang memungkinkan terjadi diskusi tanya jawab antara peserta dengan pakar dari universitas, aplikasi Positive Links yang memungkinkan penggunanya untuk mendapatkan informasi terkait pencegahan, pengobatan maupun informasi kesehatan lainnya yang terkait dengan HIV, penggunaan media texting/chatting terenkripsi untuk melakukan konseling antara konselor dengan penderita HIV. ${ }^{30,31}$

c. Mobilisasi Komunitas

Sebuah penelitian di Peru menggunakan pendekatan mobilisasi komunitas dengan menyasar kelompok populasi kunci yang dinamakan "Proyecto Orgullo" (PO). Intervensi percontohan ini bertujuan untuk mengurangi risiko penularan seksual, mempromosikan perilaku pencarian layanan kesehatan, dan memfasilitasi pemberdayaan pribadi dan komunitas di antara Laki-laki yang berhubungan seks dengan laki-laki (LSL) dan wanita transgender (Waria) di Peru. PO mencakup enam elemen inti yang saling terkait: (1) sesi Kelompok Kecil untuk refleksi diri; (2) Mendukung teman sebaya dalam pencegahan HIV; (3) Mobilisasi dalam menangani masalah, dan pemberdayaan komunitas; (4) Kelompok inti (staf + relawan LSL /Waria) merancang dan melaksanakan kegiatan tersebut; (5) Ruang Proyek; (6) Publikasi. Terdapat pula intervensi melalui penyelenggaraan lokakarya yang melibatkan laki-laki dan perempuan dan membahas tujuh topik, termasuk (1) kuasa gender dan kesehatan, (2) gender dan kekerasan, (3) alkohol, (4) gender, HIV dan AIDS, (5) hubungan yang sehat, (6) hak manusia, dan (7) mengambil tindakan untuk perubahan. Penggerak komunitas juga mengembangan kepedulian bersama dan kesadaran kritis seputar HIV dan gender melalui kunjungan rumah, turnamen sepak bola, desain mural dan diskusi, "cerita digital" (film testimonial pendek) dengan diskusi tematik, pembicaraan kesehatan, dan teater yang membawakan adegan tindak kekerasan. ${ }^{32}$

Upaya mobilisasi komunitas juga dapat dilakukan pada intervensi pengobatan sebagai pencegahan atau yang disebut Treatment as Prevention (TasP) di wilayah Afrika Selatan. TasP telah diusulkan sebagai kunci untuk mengakhiri epidemi HIV. Untuk mengaktifkan TasP di negara dengan 
prevalensi tinggi, komunitas harus termotivasi untuk mengetahui status mereka, terlibat dalam perawatan, dan tetap dalam perawatan. ${ }^{33}$ Mobilisasi komunitas memiliki potensi untuk secara signifikan meningkatkan cakupan tes HIV, retensi dengan mengatasi hambatan sosial utama dalam perawatan HIV. Upaya mobilisasi komunitas dapat membantu dalam pencegahan dan manajemen penyakit, karena menekankan faktor sosial yang terkait dengan perilaku kesehatan yang berisiko, berpotensi menjangkau lebih banyak orang, dan memungkinkan keberlanjutan dalam intervensi karena umumnya menawarkan strategi praktis yang mengedepankan nilai peran aktif komunitas secara luas untuk pencegahan dan pengobatan pada kelompok yang termarjinalkan. Upaya ini juga dapat dilakukan melalui testing dan konseling berbasis komunitas, pelibatan pemangku kepentingan, membentuk koalisi komunitas, pelibatan pimpinan komunitas maupun membentuk kerjasama dengan organisasi komunitas, mendatangi ODHIV dari rumah ke rumah, pertemuan dengan komunitas maupun diskusi kelompok secara informal. ${ }^{34,35}$

\section{d. Navigator Pasien}

Intervensi navigator pasien dianggap dapat secara efektif mempertahankan ODHIV untuk tetap dapat mengakses pengobatan melalui promosi intensif dan asistensi langsung bagi ODHIV. Navigator bertugas membantu ODHIV untuk dapat menggunakan sumber daya yang tersedia dengan lebih baik, membangun komunikasi yang lebih efektif dengan penyedia layanan, mempertahankan pengobatan, dan mengarahkan pengobatan yang lebih kompleks apabila dibutuhkan. Staff yang bertugas sebagai navigator berasal dari komunitas ODHIV yang sedang menjalani perawatan, komunitas non-kesehatan terlatih dan ditugaskan untuk membangun kemampuan ODHIV agar dapat berinteraksi dengan penyedia layanan kesehatan, terkadang juga langsung mempraktekkan percakapan atau perilaku yang harus disiapkan dalam melakukan konsultasi. Navigator juga akan bertugas untuk menyemangati ODHIV, merayakan kesuksesan maupun pencapaian sebagai pasein. Navigator juga akan membantu klien untuk mengetahui sistem layanan kesehatan dan asuransi, menemani ODHIV melakukan konsultasi di fasilitas kesehatan saat ODHIV membutuhkan dan membantu mengatasi masalah yang ditemukan dalam perawatan. ${ }^{36,37}$

\section{Diagnosis Tepat Dan Cepat Termasuk Skrining Berbasis Komunitas.}

Komunitas juga dapat berperan dalam melakukan test cepat HIV guna mendukung layanan kesehatan. Tes berbasis komunitas ini dilakukan oleh kader maupun organisasi masyarakat. Hasil kaji literatur terkait pelibatan masyarakat dalam diagnosis HIV adalah sebagai berikut:

a. Testing HIV Mandiri Berbasis Komunitas

Pendekatan ini menggunakan metode pengambilan spesimen cairan oral sendiri untuk menjangkau kelompok yang lebih berisiko tinggi dengan pilihan antara pengumpulan hasil tes HIV menggunakan Website yang aman atau konseling pasca tes di klinik kesehatan seksual. Sesi ini mencakup bimbingan yang disampaikan oleh seorang dokter asal Afrika sub-Sahara dan testimoni dari ODHIV. Intervensi ini mampu menjangkau imigran Afrika sub-Sahara yang 
berisiko terinfeksi HIV, dan dengan akses terbatas ke testing HIV biasa. Intervensi ini berkontribusi terhadap peningkatan kesadaran dan berkontribusi dalam strategi promosi tes HIV. ${ }^{38}$

\section{b. Testing Berbasis Komunitas}

Testing di fasilitas kesehatan merupakan salah satu strategi utama dari program pengendalian HIV. Walaupun demikian, banyak penelitian yang telah dilakukan menunjukkan keefektifan strategi testing berbasis komunitas dalam menemukan anak yang sebelumnya belum pernah melakukan tes dan mereka yang berusia diatas 5 tahun yang memiliki interaksi terbatas dengan layanan kesehatan konvensional. Hasil penelitian ini juga menyebutkan bahwa strategi testing berbasis komunitas dapat membantu meningkatkan cakupan testing HIV terutama pada wilayah-wilayah dengan sumber daya terbatas. ${ }^{39}$ Penelitian lain menemukan bahwa testing HIV berbasis komunitas yang difasilitasi oleh kader dapat meningkatkan akses ke testing HIV dan perawatan di antara orang dewasa kulit hitam. Model efektif dan dapat diterima secara budaya ini mewakili perubahan yang kuat dalam penyediaan perawatan HIV dan menunjukkan bagaimana para pemimpin kesehatan komunitas dapat mendorong keterlibatan komunitas dalam transisi dari penelitian ke layanan. Pendekatan ini menggunakan kader kesehatan yang disupervisi dan dilatih oleh Community Liaison Officer (CLO) untuk menawarkan layanan pencegahan HIV dan testing di komunitas. Kader kesehatan juga menyediakan kombinasi layanan pencegahan HIV termasuk edukasi kesehatan dan rujukan untuk layanan sirkumsisi sukarela bagi pria, PrEP HIV, keluarga berencana dan pembagian kondom. CLO dan kader yang disupervisi oleh staf fasilitas kesehatan di wilayah jangkauan mereka dinilai dan disertifikasi dengan Index Testing Services (ITS) dan Partner Notification Services oleh Kementerian Kesehatan. ${ }^{40}$ Hasilnya menunjukkan bahwa ITS dan layanan testing berbasis komunitas yang ditargetkan merupakan strategi yang efektif untuk mengidentifikasi pria dengan HIV di Zambia. ${ }^{41}$

c. Testing HIV di Layanan Kesehatan Yang Diselenggarakan di Komunitas

Uji coba ini menjelaskan bahwa sumber daya fasilitas kesehatan yang dekat dengan komunitas dapat ditingkatkan apabila terdapat dukungan yang mengintegrasikan testing berbasis komunitas. Namun, permintaan tambahan kader kesehatan untuk ditempatkan di setiap titik wilayah tentu dapat menjadi tantangan. Ujicoba ini menunjukkan bahwa hambatan potensial lainnya (kekhawatiran tentang kerahasiaan, pengungkapan status HIV, dan stigma HIV) dapat diatasi dengan keterlibatan yang kuat dari pemimpin komunitas dan penyedia layanan kesehatan yang terpercaya, sensitisasi komunitas, dan lokasi serta waktu pengujian yang strategis. Anggota komunitas merasa bahwa dengan perencanaan dan keterlibatan strategis, tes cepat HIV oleh komunitas di fasilitas layanan kesehatan dapat menjadi strategi yang layak dan dapat diterima untuk mengatasi hambatan yang ada. ${ }^{42}$ 


\section{d. Notifikasi Pasangan Dengan Keterlibatan Organisasi Komunitas}

Dalam penelitian yang dilakukan oleh Fu et al., (2015) pelibatan komunitas juga dilakukan dalam intervensi notifikasi pasangan. Peneliti bekerjasama dengan organisasi berbasis komunitas (CBOs) untuk mengadakan intervensi testing melalui berbagai macam pendekatan termasuk intervensi berbasis web melalui website LSL atau melalui aplikasi LSL, intervensi penjangkauan oleh CBOs di tempat perkumpulan LSL (seperti bar, spa, maupun klub) dan juga rujukan sebaya. LSL yang bersedia untuk mengikuti testing akan dirujuk ke tempat yang sudah di tentukan untuk mengikuti tes rapid HIV. Setiap LSL yang dites HIV akan diwawancarai dan diminta untuk mengisi kuesioner yang berisi data sosio-demografi, perilaku seksual dan hasil tes HIV. apabila hasil tes reaktif, LSL akan diwawancarai untuk mengumpulkan informasi mengenai pasangan seksualnya, yang kemudian ikut bergabung ke dalam pilot studi dan merujuk mereka ke fasilitas kesehatan terdekat untuk melakukan tes konfirmasi HIV dan layanan HIV lanjutan lainnya. Sedangkan, bagi LSL yang negatif akan menerima konseling terkait dengan edukasi kesehatan. ${ }^{43}$

\section{Manajemen Klinis Termasuk Layanan Dukungan Diagnostik Dan Dukungan Memulai Terapi}

Komunitas memiliki peran yang sangat besar dalam memberikan dukungan untuk mengungkap status kesehatan ODHIV. Peran komunitas dalam hal ini termasuk dukugan diagnostik juga dukungan memulai terapi ART bagi penderita. Hasil kaji literatur adalah sebagai berikut:

a. Integrasi Tes Cepat HIV Dengan Layanan Diagnostik Lainnya

Pendekatan ini diawali dengan melakukan kampanye yang melibatkan berbagai fasilitas layanan kesehatan di wilayah sub-saharan Afrika dan menggabungkan multidisiplin profesi yang terdiri dari petugas laboratorium, dokter, perawat, dan konselor terlatih untuk mengadakan integrasi testing seluruh penyakit tidak menular seperti DM, Hipertensi dengan penyakit menular seperti malaria, TBC dan HIV (tes cepat HIV). Kegiatan mobilisasi komunitas satu bulan sebelum kampanye, termasuk pengumuman gereja dan masjid, pembagian poster, dan pengumuman di radio. Untuk memaksimalkan partisipasi dan mengurangi biaya transportasi, kegiatan kampanye dilakukan di tiga lokasi terkenal. Komunitas dengan HIV, suspek TB, hipertensi atau diabetes menerima konseling pasca tes dan tunjangan untuk perjalanan ke klinik. Peserta yang terinfeksi HIV bertemu dengan staf klinis dan konselor sebaya yang terinfeksi HIV langsung di tempat screening test dilakukan Peserta yang terinfeksi HIV dan suspek TB yang tidak terinfeksi HIV dijadwalkan untuk janji temu di klinik setempat. ${ }^{44}$

b. Dukungan Memulai Terapi Melalui Konselor Komunitas

Salah satu model layanan komunitas yang berhasil menghubungkan pasien dengan ART adalah Kelompok Dukungan ART Komunitas yang dijalankan di Mozambique. Kelompok ini terdiri dari pekerja kesehatan komunitas /kader yang direkrut sebagai konselor berbayar untuk memberikan testing bagi komunitas dan merujuk pasien yang mendapatkan hasil positif ke pengobatan ART 
baik layanan ART di klinik maupun di komunitas. Sebelum rujukan, para konselor akan melakukan sesi konseling kepada pasien untuk mengetahui kondisi psikologis pasien terkait status kesehatan mereka. Dukungan emosional akan diberikan selama sesi konseling ini agar pasien memiliki harapan untuk melanjutkan hidup dan bersedia mengikuti pengobatan ART. Dari model konselor komunitas ini didapatkan hasil bahwa $89 \%$ pasien yang memenuhi syarat untuk ART telah memulai pengobatan mereka. ${ }^{45}$

\section{c. Dukungan Memulai Terapi Melalui Kelompok Dukungan Sebaya}

ODHIV memiliki berbagai faktor penghambat untuk mengakses ART, seperti hambatan sosial (stigma negatif, diskriminasi), psikologi (stres, depresi, hilangnya harapan hidup), faktor penghambat ekonomi (biaya untuk mengakses ART termasuk biaya layanan dan transportasi) dan konsepsi yang salah mengenai HIV berkontribusi pada rendahnya inisiasi dan retensi ART. KDS sangat dibutuhkan oleh ODHIV untuk mendorong mereka mengikuti ART, baik yang sudah memenuhi syarat untuk ART maupun pasien yang masih dalam tahap pre-ART. Beberapa cara yang digunakan oleh kelompok dukungan ini untuk meningkatkan partisipasi ODHIV dengan ART adalah melalui pesan singkat (SMS, whatsapp dII), pendukung pengobatan sebaya, melakukan observasi langsung pada pasien dalam pengobatan, edukasi dan konseling serta menyalurkan ODHIV dengan kelompok yang dapat memberi pekerjaan (income generation group). Model dukungan sebaya terbukti membantu ODHIV menghadapi stres dan depresi akibat diagnosa, meningkatkan kesediaan untuk memulai pengobatan ART dan meningkatkan perilaku perawatan diri. ${ }^{46}$

\section{Dukungan Pengobatan; Retensi, Manajemen Mandiri, Dan Dukungan Sebaya}

Beberapa studi menyebutkan bahwa memisahkan ART dari fasilitas kesehatan menunjukkan hasil yang mungkin dilakukan. Pelibatan komunitas dalam pengobatan HIV dapat dimulai dengan membentuk Model ART di level komunitas. Berdasarkan hasil Kaji literatur bentuk pelibatan komunitas dalam pendistribusian obat, manajemen mandiri, retensi dan dukungan sebaya sebagai berikut:

\section{a. Distribusi ART Berbasis Komunitas}

Kelompok ini dibentuk di Democratic Republic of Congo dengan alasan tingginya biaya konsultasi dan transportasi ke fasilitas kesehatan sehingga banyak ODHIV tidak mengakses pengobatan HIV. Kelompok komunitas ODHIV dilatih untuk menyediakan pengisian ulang ART, dukungan kepatuhan ART dan melakukan penelusuran pasien. Kelompok ini juga melakukan penjangkauan untuk mencari ODHIV yang belum ART. Mekanisme kerja kelompok ini adalah mengumpulkan ODHIV dengan kondisi stabil untuk melakukan pengambilan ART setiap 3 bulan dan melaporkan kondisi kesehatan kepada fasilitas kesehatan tiap tahunnya. Seluruh jadwal dipantau penuh oleh kelompok tersebut. Jika ada ODHIV yang tidak muncul saat jadwal (pengambilan ART atau konsultasi kesehatan), kelompok ini akan melakukan penelusuran melalui telepon. ${ }^{46}$ 
b. Distribusi ART dengan Prinsip Manajemen Mandiri Melalui Kelompok ART Komunitas

Tingginya biaya transportasi untuk mengunjungi fasilitas kesehatan dan kurangnya fasilitas kesehatan yang menyediakan ART maka dibentuklah Kelompok ART Komunitas di Mozambique. Dalam metode ini, terdapat beberapa orang ODHIV dengan kondisi stabil yang membentuk kelompok. Satu orang ODHIV akan mengambil ART tiap bulannya dan membagikan kepada anggota kelompoknya. Setiap 6 bulan, tiap kelompok diwajibkan untuk konsultasi kesehatan di fasilitas kesehatan. Model pelibatan ini menjadi metode dengan kendali penuh pada komunitas walaupun diperlukan monitoring yang kuat dari penyelenggara (organisasi komunitas maupun pemerintah). Selain kelompok untuk mendistribusikan ART, komunitas juga berperan dalam mendukung kepatuhan ODHIV dalam meminum ART serta memberikan dukungan emosional selama pengobatan berlangsung. ${ }^{47,48}$

c. Dukungan Retensi Pengobatan Melalui Kelompok Kepatuhan Minum ART

Banyaknya ODHIV dalam pengobatan HIV memunculkan masalah baru yaitu tingginya angka lossto follow-up. Retensi yang rendah ini mendorong fasilitas kesehatan membentuk kelompok kepatuhan minum ART yang terdiri dari pendidik sebaya untuk memberikan konsultasi kepada ODHIV mengenai permasalahan yang menyebabkan putus obat. Strategi ini merupakan jalan pintas untuk memperpendek jarak antara fasilitas kesehatan dan ODHIV dengan membawa konsultasi lebih dekat kepada komunitas. ODHIV yang boleh mengikuti kelompok ini adalah yang memiliki kondisi stabil atau telah meminum ART teratur minimal 12 bulan. Tiap bulannya kelompok yang terdiri dari maksimal 30 orang mengadakan pertemuan untuk menguatkan satu sama lain. Selain itu diadakan pula sesi konsultasi mengenai permasalahan yang dihadapi selama dalam pengobatan ART. Kelompok ini juga memberikan penjelasan kewajiban ODHIV untuk melakukan pemeriksaan laboratorium di fasilitas kesehatan tiap 6 bulan sekali. ${ }^{47}$

d. Dukungan Komunitas Terhadap Program HIV Melalui Kelompok/Organisasi Masyarakat

Berbagai faktor penghambat ODHIV untuk mengakses dan taat pada pengobatan ART. Namun beberapa studi menunjukkan berbagai bentuk dukungan komunitas membantu mengatasi masalah tersebut dan meningkatkan kepatuhan terhadap ART. Beberapa kelompok komunitas tersebut antara lain kelompok dukungan HIV, kelompok adat atau kelompok yang diprakarsai oleh komunitas seperti kelompok agama, kelompok petani, kelompok dansa, kelompok wanita (PKK), kelompok remaja (PIK-R), kelompok kunjungan rumah, kelompok keluarga dan lainnya. Pada intinya kelompok tersebut memberikan dukungan emosional, praktikal dan material kepada ODHIV untuk menjalani pengobatan ART dan patuh terhadap jadwal pengobatannya. Partisipasi sosial dari komunitas sangat penting karena berdasarkan hasil studi, ODHIV yang tidak patuh bukan karena mereka melupakan jadwal minum obat namun kehilangan harapan untuk hidup. Seringkali hal ini ditimbulkan oleh stigma negatif yang sudah melekat terhadap ODHIV. Sehingga dukungan emosional dan material untuk melanjutkan pengobatan ART sangatlah diperlukan dari orang-orang yang dekat dengan ODHIV. ${ }^{49}$ 


\section{Dukungan Psikososial Dalam Konteks Lokal/Kultural/Keagamaan}

Komunitas juga dapat dilibatkan dalam memberikan dukungan psikososial bagi ODHIV yang menjadi akar masalah keengganan mereka untuk melakukan test serta memulai pengobatan. Stigma dan diskriminasi menjadi permasalahan mendasar yang menyebabkan hal tersebut. Komunitas sendiri melalui organisasi keagamaan dan organisasi budaya/lokal dapat memberikan rasa aman dan nyaman bagi ODHIV dan kelompok beresiko tinggi untuk mengikuti program HIV. Hasil kaji literatur adalah sebagai berikut:

\section{a. Intervensi Ditempat Cukur Rambut (Barbershops)}

Sebuah pilot studi yang dinamakan Barbershop Talk With Brother (BTWB), menggunakan kelompok komunitas khusus untuk mempromosikan pengurangan risiko HIV. Intervensi BTWB menunjukkan beberapa informasi penting untuk mendukung program dan evaluasi berkelanjutan. secara khusus program BTWB menunjukkan bahwa (1) Barbershops mau untuk terlibat dalam kerjasama untuk menurunkan risiko infeksi HIV diantara pelanggannya, (2) melalui penjangkauan barbershop, peneliti dapat melibatkan laki-laki heteroseksual yang berisiko tinggi dalam penularan HIV, (3) pendekatan kolaboratif untuk mengimplementasikan program yang layak untuk dilakukan (4) Prosedur pemeriksaan dan evaluasi yang berbasis Audio Computer-Assisted Self-Interviewing (ACASI) dapat dilakukan, dan (5) program tersebut memiliki potensi keefektifan. Proyek BTWB telah berhasil dalam hal mengidentifikasi komunitas kunci, khususnya tukang cukur, untuk mendukung kerjasama antara komunitas-akademik yang berbasis komunitas. Para tukang cukur yang bergabung dalam program BTWB dapat secara nyata menjadi pemimpin dalam komunitas dan sekaligus memberikan edukasi kesehatan serta mengatasi masalah kesehatan yang umumnya dialami oleh komunitas. Dalam program tersebut, ditemukan pula tukang cukur dapat berperan penting dalam memberikan wawasan tentang jenis program kesehatan, salah satunya mengenai pencegahan HIV, yang dapat dilakukan di barbershops. ${ }^{50}$

b. Pelibatan Komunitas Melalui Organisasi Keagamaan (Faith Based Organization)

Keterlibatan komunitas melalui organisasi keagamaan dalam perawatan ODHIV remaja untuk menurunkan kesenjangan cakupan layanan HIV diantara remaja Afrika-Amerika, adalah hal yang sangat penting untuk menemukan solusi yang efektif untuk memperluas jangkauan pencegahan HIV berbasis bukti. Pada penelitian ini ditemukan beberapa faktor pendukung dan penghambat dari pelibatan komunitas melalui organisasi keagamaan. Organisasi keagamaan populasi AfrikaAmerika dikenal secara umum sebagai tempat terpercaya sebagai sumber penyebaran informasi, memiliki penasehat, panutan, dan kesempatan untuk memperkuat layanan sosial yang positif dan norma-norma baik, yang dapat menurunkan risiko penularan HIV. Prinsip-prinsip alkitab sering kali menjadi dasar untuk pencegahan HIV di kalangan remaja Afrika-Amerika. Cerita dan kutipan Alkitab biasanya digunakan untuk menghubungkan prinsip-prinsip gereja dengan perilaku remaja yang diinginkan. Hambatan dari pelibatan organisasi keagamaan dalam upaya promotif ini diantaranya adalah keengganan komunitas untuk berbicara tentang HIV di komunitas. Terkadang, 
pendeta juga merasa putus asa dan kewalahan dengan tugas melawan sekumpulan komunitas yang memiliki kehidupan "bebas". Temuan ini memberi kesan bahwa organisasi dan pemimpin berbasis agama diposisikan secara unik untuk menjadi sumber penting dalam mengurangi kesenjangan HIV remaja Afrika-Amerika. ${ }^{51}$

c. Dukungan Psikososial Pengobatan HIV Melalui Dukungan Sebaya

Dukungan sebaya untuk pengobatan (Treatment Partners - TP): termasuk keluarga, tetangga, teman, orang-orang yang bertukar barang dan jasa dengan pasien, rekan kerja dan kenalan dari gereja, masjid, dan klinik kesehatan. TP bertugas untuk meningkatkan kepatuhan ODHIV terhadap ART. TP dapat ditawarkan secara langsung, melalui telepon, dan pengingat pesan teks. TP harus memastikan pasien mendapat makanan, untuk meningkatkan ketahanan terhadap pengobatan. TP merupakan intervensi kepatuhan yang dikembangkan di sub-Sahara Afrika. Empat fungsi sosial diidentifikasi dari program intervensi TP ini antara lain (1) mendorong ODHIV untuk terbuka; (2) memerangi stigma; (3) memulihkan harapan; dan (4) mengurangi perbedaan sosial. Fungsi-fungsi ini bekerja untuk memulihkan hubungan sosial dan membalikkan efek HIV/AIDS dari yang mengisolasi, menuju ke memperkuat akses ke jaring pengaman komunitas yang penting. Selain mendorong kepatuhan ART, TP berkontribusi pada kesehatan sosial pasien. Kesehatan sosial serta keberhasilan pengobatan HIV sangat penting untuk kelangsungan hidup orang yang hidup dengan HIV / AIDS di Afrika sub-Sahara. 52

\section{Komunikasi dan Koordinasi Antar Organisasi Penyedia Layanan, Pasien Dan Komunitas/Organisasi Komunitas}

Hasil kajian literatur terkait pelibatan komunitas dalam komunikasi dan koordinasi antar organisasi, pasien dan komunitas terangkum seperti di bawah ini:

a. Komunikasi Dan Koordinasi Antara Layanan Kesehatan Dengan ODHIV

Intervensi ini bertujuan untuk mempromosikan keterlibatan jejaring dalam penyediaan layanan HIV melalui suatu kelompok kecil (anggota kelompok dapat berasal dari tetangga, kerabat maupun teman) untuk mendukung psikososial dan kepatuhan ART. Setiap tim terdiri dari 5-15 orang yang terlibat dalam proses rekrutmen sebagai berikut: 1) kader kesehatan diundang ke dalam kelompok komunitas yang sudah ada, seperti kelompok gereja, kelompok pekerja sosial, dll 2) Staf program membantu pasien yang memakai ART untuk merekrut kelompok informal yang berpusat pada pasien yang terdiri dari keluarga, teman dan tetangga yang biasanya mereka andalkan untuk mendapatkan dukungan. Setelah terdaftar, setiap peserta didaftarkan di satu mikroklinik saja, dan setiap mikroklinik berisi kader kesehatan setempat, yang sebelumnya dilatih oleh Kementerian Kesehatan. ${ }^{53}$

Selain itu ada juga project LTC yang hanya merujuk ODHIV ke fasilitas kesehatan dan kemudian memverifikasi dengan mengunjungi, meninjau dan mengkonsolidasikan sumber data rujukan fasilitas kesehatan termasuk data pemantauan dan evaluasi nasional untuk ART, pemeriksaan CD4, register terduga TB, dan file pasien menggunakan daftar rujukan. ODHIV yang belum melakukan 
perawatan kemudian diingatkan melalui panggilan telepon, layanan pesan singkat atau kunjungan rumah untuk mengunjungi fasilitas kesehatan. Sejumlah tantangan diantaranya adalah rendahnya keterkaitan dengan ART dan komunitas pendukung harus menyediakan transportasi untuk diri mereka sendiri dan ODHIV yang tidak memiliki uang. Tantangan lain termasuk antrian panjang ODHIV dan membutuhkan waktu sehari penuh untuk memulai ART di klinik sehingga ODHIV baru menghindari mengunjungi klinik. ${ }^{54}$

b. Pelibatan Komunitas Melalui Organisasi Berbasis Komunitas (Community Base Organization - CBO) Beberapa penelitian menyebutkan bahwa dengan keterlibatan CBO yang lebih tinggi secara signifikan lebih mungkin meningkatkan penggunaan kondom yang konsisten. CBO memberikan nilai tambah dalam menangani epidemi HIV dengan cara yang spesifik dan terkait erat dengan layanan yang mereka sediakan (misalnya, pendidikan pencegahan). Dengan demikian, meningkatkan keterlibatan CBO dapat menjadi ukuran yang efektif dalam meningkatkan upaya pencegahan HIV. ${ }^{55}$

Pelibatan komunitas melalui pimpinan komunitas juga pernah dilakukan dalam rangka mempromosikan partisipasi pria dalam pencegahan penularan dari ibu ke anak (PPIA) dan tes HIV pasangan. Program tersebut terbukti mendorong perubahan sikap dan perilaku antara ibu hamil dan pasangannya. Komunikasi dan koordinasi antara layanan kesehatan dengan komunitas juga pernah dilakukan melalui Avahan Project yang dilaksanakan di India. Proyek tersebut ditujukan mengurangi infeksi HIV dengan mempromosikan perilaku pengurangan risiko dan membangun lingkungan yang mendukung di antara kelompok berisiko tinggi. Kegiatannya termasuk drop-in center, penjangkauan dukungan sebaya, distribusi kondom, respon krisis dan layanan untuk infeksi menular seksual (IMS). Komponen mobilisasi komunitas dalam proyek ini terdiri dari pekerjaan untuk melibatkan pekerja seks dalam kegiatan, mulai dari mendorong partisipasi dalam pemetaan dan penjangkauan komunitas dan keanggotaan dalam komite proyek, hingga memfasilitasi manajemen tim cepat tanggap. ${ }^{56}$

\section{Pelibatan Komunitas Dalam Penelitian HIV}

Peran komunitas dalam pengendalian HIV tidak hanya berada dalam tahap promosi, pencegahan, testing maupun kuratif, namun komunitas juga dapat berperan dalam penelitian HIV. Melibatkan komunitas dalam penelitian HIV dapat dilakukan pada:

\section{a. Penelitian HIV Dengan Metode Crowdsourcing}

Salah satu metode potensial untuk melibatkan komunitas dalam penelitian adalah crowdsourcing. Metode ini merupakan pendekatan yang memberikan kesempatan bagi komunitas untuk memecahkan masalah, memberikan pendapatnya pada suatu isu/topik/masalah dan membagikan hasil yang telah disepakati kepada publik. Metode ini sangat memberikan peluang bagi komunitas untuk aktif dalam penelitian/penentuan program dan metode penelitian kesehatan. Beberapa penelitian terkait HIV yang menggunakan metode crowdsourcing adalah: 


\section{i. Uji Klinis}

Komunitas dapat dilibatkan dalam menilai transparansi ujicoba klinis itu sendiri dengan cara memberikan umpan balik terhadap peneliti mengenai bagaimana teknik yang mudah bagi komunitas untuk mempelajari ujicoba klinik terkait HIV, bagaimana cara komunikasi yang lebih baik kepada partisipan yang memenuhi syarat, perlakukan pasca-penelitian dan bagaimana cara mengkomunikasikan hasil penelitian kepada komunitas. Sebuah studi menunjukkan bahwa komunitas juga memiliki ketertarikan yang tinggi terhadap penelitian kesehatan, namun memang diperlukan suatu cara untuk mengkomunikasinya dengan mudah. Dengan melibatkan komunitas itu sendiri dalam suatu penelitian kesehatan menghasilkan keuntungan sendiri dimana intervensi/program HIV yang dijalankan nantinya sesuai dengan kebutuhan komunitas serta memiliki tingkat penerimaan yang baik. ${ }^{57}$

ii. Penelitian Mengenai Pengobatan HIV

Penelitian HIV seringkali menimbulkan efek samping yang tinggi bagi partisipannya. Sehingga timbul keengganan komunitas memberikan partisipasinya pada percobaan HIV. Melibatkan komunitas dalam tahap awal perencanaan penelitian HIV akan meningkatkan kepercayaan komunitas terhadap intervensi hasil penelitian. Banyaknya mitos terkait pengobatan HIV, ketidakpercayaan komunitas terhadap peneliti, tingginya resiko dari penelitian sendiri mendorong peneliti untuk menemukan metode baru untuk mengkomunikasikan tantangan sosial dan prosedur etik mengenai penelitian HIV dengan melibatkan komunitas. Selain itu dilakukan juga diskusi dengan komunitas untuk menemukan cara meningkatkan motivasi dan keterlibatan komunitas dalam pengobatan HIV dengan cara yang kreatif. Dengan melibatkan komunitas dalam tahap awal penelitian akan meningkatkan partisipasi dan menghasilkan ideide kreatif yang dibutuhkan. ${ }^{58}$

\section{b. Pelibatan Komunitas dengan Metode Penelitian Partisipatif}

Merupakan pendekatan kemitraan antara peneliti, anggota komunitas dan perwakilan organisasi komunitas dalam memberikan kontribusi keahlian serta pengambilan keputusan penelitian. Beberapa pelibatan komunitas dalam penelitian yang menggunakan metode ini adalah:

\section{i. Pengembangan PrEP Tool Kit}

Pengembangan PrEP Tool Kit dilakukan secara partisipatif dengan melibatkan kelompok minoritas seperti LSL dan membentuk tim yang disebut investigator. Kelompok ini terlibat dalam setiap tahapan penelitian termasuk mengembangkan pertanyaan penelitian, pengembangan desain studi, partisipasi dalam pengumpulan data primer dan proses analisis, serta partisipasi dalam penulisan laporan dan diseminasi hasil penelitian. Hasil dari proses Community Based Participatory Research (CBPR) ini adalah kaum minoritas seksual mampu mengembangkan PrEP Tool Kit Step by Step, dimana dalam tool kit itu memuat informasi mengenai dan cara mengakses PrEP. Metode CBPR meningkatkan peran komunitas minoritas 
dan rasa kepemilikan mereka terhadap suatu program HIV dengan membangun kapasitas komunitas. ${ }^{59}$

ii. Pengembangan Instrumen Status HIV Disabilitas (HIV Disability Questionnaire - HDQ)

Pelibatan komunitas ODHIV dalam tahap awal penelitian yang kemudian bergabung menjadi Komite Penasihat Komunitas (Community Advisory Committee). Komite ini bekerjasama dengan peneliti untuk mengembangan HIV Disability Questionnaire (HDQ) dimana ODHIV dengan disabilitas bisa mengisi sendiri kuesioner tersebut untuk mengungkapkan status disabilitas mereka. Komite Penasihat ini berperan aktif memberikan input mengenai pertanyaan yang masuk dalam kuesioner dan pertanyaan apa yang harus dihilangkan. Selain itu, mereka juga memberikan masukan mengenai peluang untuk mengaplikasikan kuesioner ini dalam program HIV. Pelibatan komunitas dalam pengembangan instrumen sangat berguna untuk memastikan kuesioner yang dihasilkan relevan dengan budaya, sensitif terhadap kelompok HIV dan dapat diaplikasikan sesuai dengan kepentingan komunitas. ${ }^{60}$

\subsubsection{Pk2. Apakah Kelebihan Dan Kelemahan Dari Metode Pelibatan Komunitas Yang Telah Diterapkan Tersebut?}

\section{Pelibatan Komunitas Dalam Upaya Promotif Dan Preventif HIV}

Pengendalian HIV akan sangat efektif apabila melibatkan seluruh komponen komunitas sehingga setiap warga mengerti tentang HIV, mau berpartisipasi serta mampu untuk secara bersama-sama menanggulangi HIV. Kelebihan dan kelemahan dari pelibatan komunitas yang paling terdampak dalam upaya promotif dan preventif dari kajian literatur adalah sebagai berikut.

Kelebihan pelaksanaan upaya promotif preventif dengan melibatkan komunitas

a. Memberikan dukungan sosial dan emosional sehingga berpotensi menghilangkan stigma, diskriminasi pada ODHIV dan kekhawatiran akan pengungkapan status HIV.

b. Meningkatkan perawatan HIV dan cakupan ART pada wilayah dengan prevalensi HIV tinggi.

c. Meningkatkan literasi tentang kesehatan terutama HIV.

d. Berguna sebagai strategi yang baik untuk mengendalikan epidemi HIV.

e. Mempengaruhi kepercayaan populasi kunci akan pencegahan HIV, kesadaran diri (self-efficacy) dan perilakunya.

f. Meningkatkan penggunaan kondom, kapasitas dan kohesi sosial.

g. Meningkatkan keterlibatan komunitas melalui kelompok komunitas strategis dalam program kesehatan.

h. Organisasi berbasis komunitas (CBO) sangat mudah untuk menjangkau kelompok berisiko tinggi.

i. Lebih banyak kelompok komunitas yang sadar pentingnya mengetahui status HIV termasuk meningkatkan angka testing HIV dan PPIA di fasilitas kesehatan.

j. Meningkatkan rujukan dan retensi ke layanan pengobatan HIV.

k. Mempromosikan kepatuhan dan konsistensi konsumsi ART termasuk konseling kesehatan. 
Kelemahan pelaksanaan upaya promotif preventif dengan melibatkan komunitas

a. Terkadang pendekatan yang dilakukan hanya menjangkau komunitas tertentu saja

b. Membutuhkan literasi yang tinggi apabila melakukan kampanye sosial melalui internet dan hanya dapat menyasar komunitas yang memiliki akses ke internet.

\section{Pelibatan Komunitas dalam Dukungan Diagnostik dan Pelaksanaan Testing Mandiri}

Pencegahan penularan HIV terhadap komunitas dapat diatasi jika dilakukan tes HIV secara dini. Deteksi dini terhadap penularan HIV yang dilakukan secara mobile dan mendekati lingkungan populasi kunci merupakan layanan yang melibatkan unsur komunitas. Unsur komunitas tersebut disebut dengan pemangku kepentingan meliputi tokoh komunitas, populasi kunci, populasi berisiko, pimpinan wilayah, tenaga kesehatan, instansi pelayanan kesehatan, dan dinas kesehatan setempat.

\section{Kelebihan pelaksanaan testing berbasis komunitas}

a. Meningkatkan angka capaian testing HIV bagi semua komunitas terutama bagi kelompok yang termarjinalkan dan populasi kunci.

b. Menurunkan angka kasus infeksi baru HIV tanpa memberikan beban baru pada sistem kesehatan.

c. Memiliki tingkat penerimaan lebih baik dari populasi kunci dibandingkan testing di fasilitas kesehatan, terutama apabila pemimpin komunitas ikut terlibat dalam peningkatan kesadaran mengenai HIV.

d. Testing berbasis komunitas secara efektif menjangkau dalam menemukan kelompok yang belum pernah mengikuti tes, terutama bagi mereka yang tidak memiliki akses memadai untuk mendatangi fasilitas kesehatan.

e. Menghubungkan orang dengan hasil tes HIV positif ke layanan pengobatan.

f. Model yang terbukti bermanfaat dan diterima secara budaya merupakan dasar yang kuat untuk membawa perubahan bagi metode perawatan ODHIV.

g. Memungkinkan untuk mengurangi stigma di komunitas apabila menjadi layanan rutin yang biasa dilaksanakan di fasilitas kesehatan.

Kelemahan pelaksanaan testing berbasis komunitas

a. Memerlukan uji coba yang cukup banyak di komunitas dan dievaluasi secara berkelanjutan efektivitasnya sebelum menjadi program nasional.

b. Ketakutan komunitas akan stigma HIV, ketakutan akan pengungkapan status HIV dan tingginya beban kerja kader kesehatan.

c. Keterbatasan sumber daya; dana, fasilitas laboratorium, infrastruktur, akses untuk melatih konselor dan layanan rujukan untuk ART.

\section{Model Dukungan Komunitas Terhadap Memulai Terapi, Distribusi Dan Kepatuhan ART}

Terdiri dari tempat distribusi ART di Komunitas (Community ART Distribution Points), Kelompok ART Komunitas, adherence club, konselor komunitas dan dukungan Komunitas terhadap Program HIV melalui Kelompok/Organisasi Komunitas. Dilaporkan dari beberapa studi terdapat keuntungan dengan menempatkan ART distribusi di komunitas dan bukan fasilitas kesehatan antara lain: 


\section{Kelebihan Pelaksanaan Distribusi ART berbasis Komunitas}

a. ODHIV dengan virus tersupresi yang mendapatkan ART di fasilitas kesehatan dengan di komunitas menunjukkan hasil yang sama.

b. Menurunnya lost to follow up pasien karena kemudahan untuk mengakses ART.

c. Mengurangi beban finansial (biaya obat serta transportasi) untuk mendapatkan ART di fasilitas kesehatan.

d. Komunitas yang membagikan ART merupakan kelompok yang dipercaya oleh pasien sehingga meningkatkan kepercayaan diri.

e. Meningkatkan kepatuhan ODHIV untuk meminum ART karena dukungan dari kelompok komunitas (kelompok ART, kelompok kunjungan rumah, dukungan sebaya, income generation group, dll) yang mengatasi masalah psikologis, sosial-ekonomi dan struktural yang menghambat ODHIV mengakses ART.

f. Fasilitas kesehatan dapat membagi tanggung jawabnya dengan komunitas dan memberikan peluang bagi tenaga medis untuk memfokuskan sumber dayanya merawat pasien sakit (ODHIV dalam kondisi tidak stabil).

Tantangan/kekurangan model pelibatan komunitas dalam program ART

a. Memerlukan komunitas/pimpinan organisasi yang memiliki pengetahuan, kemampuan dan kepemimpinan serta motivasi tinggi dalam menjalankan distribusi ART.

b. Terkadang timbul konflik internal dalam kelompok distribusi ART sehingga (organisasi komunitas/pemerintah) memerlukan strategi untuk menghindari timbulnya konflik.

c. Memerlukan monitoring yang kuat dari komunitas/pemerintah/tenaga kesehatan terkait distribusi ART, konseling dan tindakan yang dilakukan oleh kelompok komunitas.

d. Stigma yang berkembang di komunitas terkait HIV menyebabkan keengganan mereka untuk bergabung dalam kelompok ART ini. Untuk bergabung dalam kelompok ART berarti mereka harus siap mengungkapkan status mereka.

e. Untuk merekrut ODHIV maupun komunitas bergabung dalam kelompok ART/ aktif dalam program HIV maka diperlukan skema insentif yang dapat menarik minat mereka (insentif finansial/nonfinansial).

f. Karakteristik demografi yang sangat berbeda diantara ODHIV menjadi tantangan sendiri untuk menggabungkannya dalam satu kelompok.

\section{Pelibatan Komunitas Dalam Penelitian}

Pelibatan komunitas dalam tahapan awal penelitian/program kesehatan bukanlah hal yang baru namun masih jarang dilaksanakan. Berikut beberapa faktor pendukung dan tantangan yang dirangkum dari berbagai artikel mengenai pelibatan komunitas dalam perancangan penelitian HIV.

Faktor pendukung pelibatan komunitas dalam Penelitian HIV

a. Merupakan metode yang memungkinkan untuk diterapkan. 
b. Komunitas ternyata memiliki ketertarikan tinggi dengan dunia medis termasuk penelitian, sehingga memudahkan peneliti untuk melibatkan mereka/memperoleh masukan mengenai suatu program kesehatan dari komunitas.

c. Media sosial sebagai media promosi sangatlah disukai komunitas sehingga dapat digunakan sebagai media untuk melibatkan komunitas.

Tantangan dalam melibatkan komunitas dalam penelitian HIV

a. Perbedaan literasi komunitas terhadap informasi maupun penelitian HIV sangatlah berbeda-beda sehingga diperlukan metode pemilihan responden untuk mengurangi bias seleksi (kecenderungan untuk memilih hanya responden yang memiliki pengetahuan baik terhadap HIV).

b. Komunitas memiliki hambatan sosial ekonomi yang berbeda-beda untuk berpartisipasi dalam penelitian HIV. Oleh karena itu, peneliti harus mampu menawarkan insentif (finansial maupun non finansial) agar komunitas tertarik berpartisipasi.

c. Stigma yang berkembang di komunitas terkait ODHIV maupun kelompok minoritas seksual sehingga timbul keraguan untuk bersedia bergabung dalam penelitian HIV. Jika bergabung maka dianggap mengungkapkan status HIV ke publik.

d. Pekerja medis (dokter, perawat, dll) memiliki peran penting untuk meningkatkan kepercayaan komunitas kepada program/intervensi kesehatan. Pekerja medis harus aktif mempromosikan program atau memberikan informasi kesehatan yang menurunkan stigma serta menghilangkan mitos yang beredar di komunitas.

\subsubsection{Pk3. Bagaimanakah Integrasi Pelibatan Komunitas Untuk Program HIV Dalam Kerangka SKN?}

Dalam integrasinya dengan SKN, layanan komunitas dapat terintegrasi pada dua sistem yaitu sistem layanan kesehatan dan komunitas. Peran ini terjadi dalam kesatuan rangkaian (continuum) mulai dari tingkatan koordinasi, kolaborasi dan integrasi. Adapun tahapan integrasi tersebut adalah:

1. Koordinasi; Dalam tingkatan ini terdapat komunikasi untuk saling merujuk pasien antara layanan kesehatan dengan layanan komunitas.

2. Kolaborasi; Pada tahapan kolaborasi komunikasi terjalin erat dan terdapat database pasien bersama antara layanan kesehatan dengan layanan komunitas. Tahapan ini memudahkan komunikasi antara layanan dan sistem rujukan pasien yang makin jelas. Pada tingkat kolaborasi, kedua layanan melakukan perencanaan dan evaluasi kegiatan program bersama. Kolaborasi juga berarti penyusunan standar operasi bersama dan penghimpunan sumber daya untuk dikelola bersama.

3. Integrasi; Pada tingkatan integrasi penyedia layanan kesehatan maupun komunitas terlibat bersama dalam pengambilan keputusan klinis dalam layanan kesehatan. Pada tahapan ini, suatu program kesehatan tidak akan berjalan dengan baik tanpa adanya kontribusi antara satu layanan dengan lainnya. 
Berdasarkan hasil Kajian Literatur Sistematis diatas, maka layanan komunitas akan dikelompokkan berdasarkan tingkatan continuum of integration layanan HIV yang melibatkan komunitas.

\section{Koordinasi}

a. Edukasi Melalui Kelompok Dukungan Sebaya. Melalui kelompok dukungan sebaya, koordinasi layanan kesehatan dan komunitas dilakukan dengan membuka jalur saling rujuk untuk ART dan dukungan komunitas. Selain memberikan jalur rujukan, dalam kelompok dukungan sebaya, komunitas akan memberikan masukan mengenai rencana terapi yang dapat diterima ODHIV dan melakukan identifikasi alasan mengapa ODHIV mengalami kesulitan memulai terapi. Penyedia layanan kesehatan dapat memberikan ART dan juga merujuk pasien untuk mendapatkan dukungan komunitas.

b. Pelibatan Komunitas Melalui Promosi di Radio/Internet/Aplikasi/Web-Based. Media dibutuhkan tidak hanya sebagai media edukasi namun juga sebagai saluran untuk membuka rujukan bagi anggota populasi kunci yang terjangkau. Melalui metode ini, layanan kesehatan berperan untuk menerima rujukan kasus berisiko tinggi yang telah terjangkau melalui media tersebut. Sedangkan komunitas akan berperan untuk melaksanakan penjangkauan ke lapangan dan merujuk kasus yang teridentifikasi berisiko tinggi.

c. Navigator pasien/ODHIV (layanan pendampingan pasien). Dalam melakukan pendampingan ODHIV, penyedia layanan kesehatan dan komunitas dapat melakukan kolaborasi dalam penyusunan standar operasional layanan kesehatan yang mudah dimengerti pasien dan komunitas serta menyediakan saluran komunikasi untuk membantu ODHIV dan pendamping komunitas. Peran penyedia layanan adalah menyediakan jalur komunikasi bagi komunitas untuk membantu ODHIV dalam menavigasi sistem pelayanan kesehatan dan komunitas akan berperan dalam menyusun standar layanan HIV bersama komunitas dan menyediakan pendamping yang membantu ODHIV menavigasi sistem layanan HIV.

d. Intervensi kelompok dukungan berbasis bukti untuk pencegahan HIV dan testing. Dalam intervensi ini, penyedia layanan kesehatan mendampingi langsung komunitas untuk dapat mencari rujukan kesehatan dan menyediakan anggota komunitas untuk melaksanakan testing di layanan kesehatan. Komunitas berperan untuk memperluas jangkauan informasi tersebut kepada populasi kunci lainnya.

\section{Kolaborasi}

a. Mobilisasi komunitas. Dalam upaya mobilisasi komunitas, terjadi kolaborasi antara komunitas dengan penyedia layanan kesehatan yaitu untuk merancang kegiatan bersama, menyusun modul yang digunakan dalam memberikan pelatihan dan edukasi, serta dapat melakukan evaluasi kegiatan bersama. Komunitas berkolaborasi dengan penyedia layanan kesehatan untuk menyasar kelompok kunci yang termarjinalkan.

b. Dukungan Memulai Terapi melalui Konselor Komunitas. Kolaborasi antara komunitas dengan penyedia layanan kesehatan dengan merekrut konselor berbayar untuk memberikan testing bagi 
komunitas dan merujuk pasien yang mendapatkan hasil positif ke pengobatan ART baik layanan ART di fasilitas kesehatan maupun di komunitas.

c. Dukungan Memulai Terapi melalui KDS. Penyedia layanan kesehatan berkolaborasi dengan komunitas dengan menggunakan mekanisme KDS untuk mengurangi diskriminasi dan stigma diantara ODHIV agar tidak merasa malu mengakses layanan kesehatan

d. Kampanye Tes Cepat HIV. Kolaborasi antara komunitas dengan penyedia layanan kesehatan dengan melaksanakan kampanye testtng HIV di lokasi-lokasi yang mudah dikenali. penyedia layanan kesehatan dapat menyediakan HIV testing kit dan melakukan konfirmasi diagnosa HIV dan merujuk kepada komunitas untuk mendapatkan dukungan perawatan.

e. Dukungan Retensi Pengobatan melalui Kelompok Kepatuhan Minum Obat. Kolaborasi penyedia layanan dengan komunitas dilakukan dalam kegiatan pembentukan kelompok kepatuhan (adherence club) yang terdiri dari peer educator dari komunitas untuk memberikan konsultasi kepada ODHIV mengenai permasalahan yang menyebabkan putus obat.

f. Dukungan Komunitas terhadap Program HIV melalui Organisasi Masyarakat. Kolaborasi ini berlangsung dua arah dimana peran komunitas melalui organisasi masyarakat (PKK, PIK-R, KDS dII) untuk memberikan intervensi berupa dukungan retensi dan kepatuhan minum ART. Sedangkan sistem kesehatan juga dapat merujuk pasien/ODHIV yang susah untuk patuh pada jadwal terapi ke kelompok komunitas tersebut untuk diawasi.

g. Barber-shops based Intervention dan pelibatan komunitas melalui organisasi keagamaan. Dukungan psikososial juga dapat diberikan oleh oleh organisasi keagamaan dan lokal. Dalam hal ini intinya kolaborasi dilakukan antara layanan kesehatan dengan kelompok komunitas yang memiliki peran besar dalam mempengaruhi persepsi masyarakat. Kelompok tersebut memberikan rasa aman dan nyaman dan dukungan bagi ODHIV dan populasi kunci dalam program HIV.

h. Dukungan psikososial Pengobatan HIV melalui dukungan sebaya (Treatment Partners). Proses kolaborasi ini berlangsung antara penyedia layanan kesehatan dan komunitas dalam memberikan dukungan psikososial (dukungan psikologis, dukungan finansial dll). Sistem kesehatan dalam hal ini berperan dalam menyediakan layanan psikososial yang dibutuhkan pasien sedangkan komunitas (kelompok sebaya) berperan dalam menjangkau ODHIV yang mengalami masalah psikososial. Kolaborasi kegiatan ini memiliki tujuan yang sama yaitu kepatuhan pengobatan ART untuk ODHIV.

i. Pelibatan Komunitas dalam Penelitian HIV dengan metode Crowdsourcing dan CBPR. Komunitas dapat berkolaborasi dengan penyedia layanan ataupun peneliti kesehatan dalam pengembangan program kesehatan, percobaan klinis maupun pengembangan instrumen penelitian. Komunitas dapat memberikan masukan terkait masalah kesehatan yang diajukan peneliti dimana masukan tersebut berperan sebagai dasar pengembangan program/penelitian HIV. Proses kolaborasi memberikan peluang bagi komunitas dan peneliti/penyedia layanan kesehatan untuk memformulasikan program yang lebih menjawab kebutuhan sasaran. 


\section{Integrasi}

a. Testing HIV mandiri. Testing HIV ini bersifat mandiri pada komunitas yang memiliki resiko tinggi. Hal ini dilakukan untuk meningkatkan kepercayaan diri komunitas untuk mengungkap status HIVnya. Tahapan integrasi antara layanan kesehatan dengan komunitas berlangsung dalam hal perencanaan kegiatan, penentuan dan cara penjangkauan sasaran, target serta evaluasi pelaksanaan program. Antara sistem kesehatan dan komunitas memiliki perannya masing-masing dalam testing dan saling ketergantungan satu sama lain.

b. Testing berbasis komunitas. Pada kegiatan ini, komunitas yang berperan adalah kader kesehatan yang direkrut dan dilatih oleh petugas penghubung komunitas untuk menyediakan tes HIV. Proses integrasi antara sistem kesehatan dan komunitas terlihat dari bagaimana dua sistem tersebut membentuk perencanaan kegiatan, penyusunan standar tes HIV serta evaluasi. Layanan kesehatan berperan dalam penyediaan SDM kesehatan (petugas penghubung komunitas), penyediaan testing-kit, serta melakukan konfirmasi diagnosa. Komunitas sendiri memiliki peran untuk menjangkau populasi kunci dan melakukan tes pada mereka dengan sebelumnya melakukan edukasi.

c. Notifikasi pasangan dengan melibatkan organisasi komunitas. Keterlibatan organisasi komunitas lebih kepada penjangkauan populasi kunci untuk melakukan testing yang dilakukan oleh tenaga kesehatan. Jika hasil reaktif, organisasi komunitas juga berperan untuk mewawancarai pasangan seksualnya dan memberikan dukungan. Proses integrasi antara sistem kesehatan dengan layanan komunitas terlihat dari pembagian peran antara testing dan penjangkauan yang direncanakan bersama-sama. Database pasien dikelola secara bersama antara layanan kesehatan dan komunitas.

d. Distribusi ART dengan Prinsip Manajemen Mandiri melalui Kelompok ART Komunitas. Pada kegiatan ini, komunitas berperan untuk mendukung fasilitas kesehatan dalam mendistribusikan ART. Komunitas yang berperan adalah ODHIV dengan kondisi stabil secara mandiri dan berdaya mengambil dan mendistribusikan ART kepada anggota kelompoknya. Kegiatan ini bersifat terintegrasi dimana fasilitas kesehatan berperan sebagai penyedia dan pengawas dan komunitas (kelompok ODHIV) berperan sebagai pengidentifikasi kebutuhan ART di komunitas serta menjangkau ODHIV yang memerlukan dukungan. 


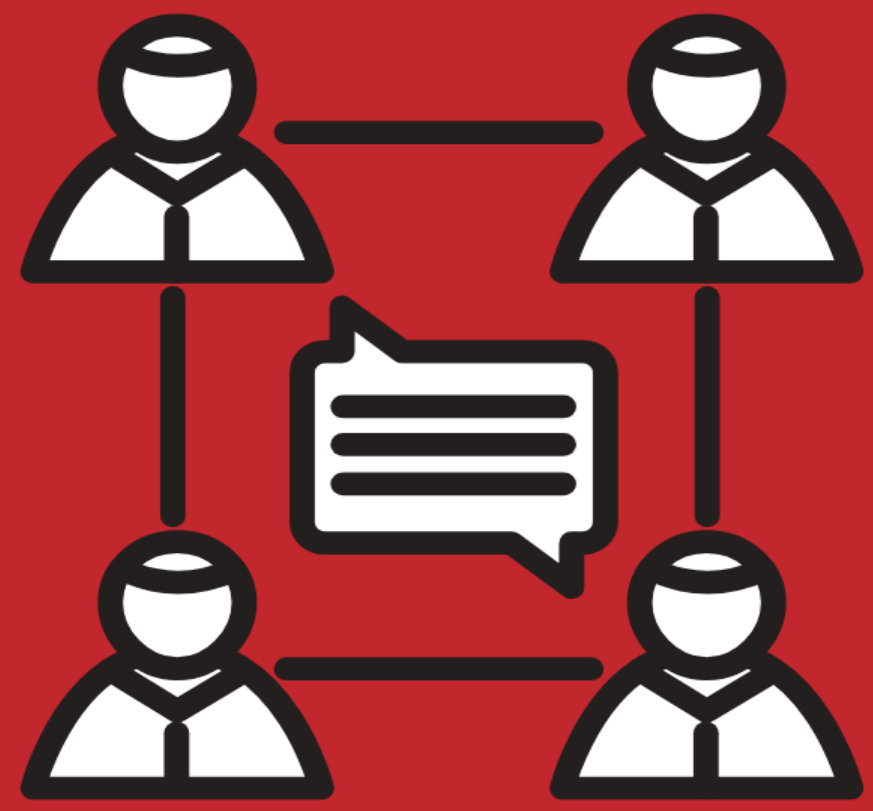

\section{Analisis Dokumen Kebijakan Pengendalian HIV}

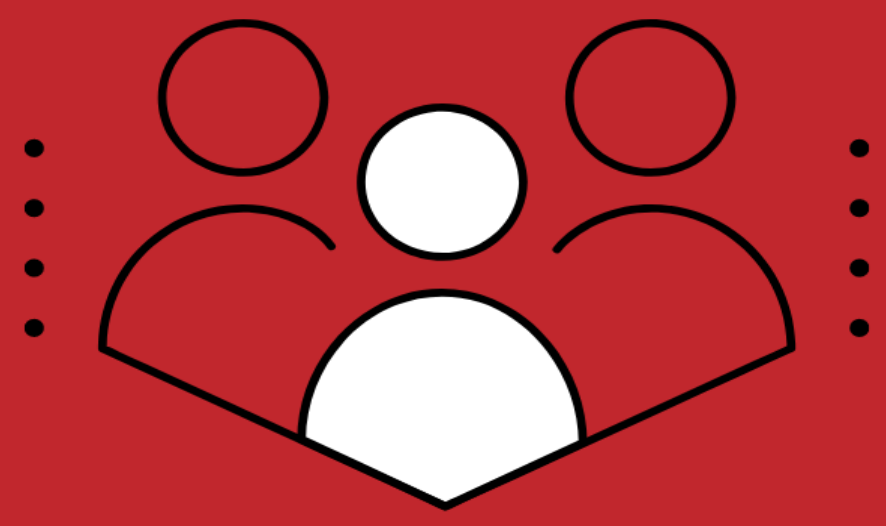




\section{Analisis Dokumen Kebijakan Pengendalian HIV}

\subsection{Deskripsi dan Tujuan}

Secara global, ada 6 strategi pencapaian target fast track 90-90-90 yang menjadi fokus kajian positioning komunitas dalam sistem kesehatan nasional, yaitu ${ }^{61}$.

1. Penyediaan layanan berbasis komunitas yang optimal dan kondusif

2. Upaya pencegahan penularan HIV berbasis komunitas

3. Upaya peningkatan jumlah tes dan akses ke layanan HIV berbasis komunitas

4. Upaya mendukung retensi dan kepatuhan terhadap ART berbasis komunitas

5. Peran komunitas dalam perluasan dan monitoring viral load,

6. Strategi berbasis komunitas dalam menyasar kelompok kunci.

Strategi di atas telah menyasar pokok-pokok penting dalam kerangka percepatan penanggulangan HIV melalui strategi 90-90-90, berdasarkan tahapannya sejak dari upaya pencegahan hingga terapi. Yang sangat penting untuk digarisbawahi demi suksesnya pelaksanaan strategi di atas adalah terjalinnya koordinasi yang harmonis dan berkelanjutan antara komunitas (baik sebagai organisasi formal maupun informal) dengan fasilitas layanan kesehatan formal yang telah ada di masyarakat. Lima hal di bawah ini adalah kunci penting terlaksananya keenam strategi di atas secara lengkap ${ }^{61}$.

1. Tersedianya kebijakan dan peraturan perundangan yang jelas

2. Penguatan jejaring kerjasama dan komunikasi antara komunitas dan fasilitas layanan kesehatan pada setiap tingkat untuk menghindari duplikasi kegiatan dan memaksimalkan hasil capaian program

3. Pengakuan dan penghargaan terhadap hasil kerja para konselor awam, konselor yang juga ODHIV, maupun relawan sangat perlu diberikan. Harmonisasi kerja dengan program di fasilitas layanan kesehatan, pemberdayaan melalui pelatihan, maupun remunerasi harus dimulai oleh kementerian kesehatan,

4. Memastikan kapasitas komunitas baik secara kelembagaan maupun individual melalui pelatihan, pendampingan maupun pengawasan yang terkoordinasi baik

5. Tersedianya pengawasan yang adequat terhadap semua intervensi/program berbasis komunitas oleh negara melalui Kementerian Kesehatan

Penguatan sistem komunitas di Indonesia merupakan bagian dari pemberdayaan masyarakat. Hal ini menjadi salah satu dari lima strategi utama rencana pembangunan kesehatan jangka panjang (20052025). Undang-Undang Nomor 36 Tahun 2009 tentang Kesehatan juga menjelaskan pentingnya pemberdayaan dan peran aktif masyarakat dalam segala bentuk upaya kesehatan. Penguatan sistem komunitas di Indonesia membantu komunitas untuk berkontribusi secara efektif dan berkesinambungan terhadap kegiatan pengendalian masalah kesehatan di tingkat komunitas, termasuk dukungan untuk pengembangan lingkungan yang kondusif dan responsif. 
Maka dari itu, pada bagian ini, melalui metode analisis dokumen kebijakan yang ada dan bisa diakses, dilakukan analisis kebijakan terkait sistem pelayanan kesehatan dan sistem pelayanan terkait HIV dari segi pencegahan maupun perawatan, dukungan, dan pengobatan (PDP) untuk mencapai target 90-90-90 pada tahun 2024 dan mengakhiri pandemi tahun 2030 dalam kaitannya dengan peran dan positioning komunitas. Secara sistematis analisis dilakukan melalui:

1. Penilaian dukungan kebijakan dan regulasi sistem layanan kesehatan HIV terkini terhadap upaya pencegahan maupun PDP untuk mencapai target 90-90-90.

2. Penilaian bagaimana desentralisasi dalam sistem pelayanan kesehatan berperan dalam program HIV dan juga positioning layanan komunitas,

3. Identifikasi positioning layanan komunitas dalam berbagai kebijakan terkait pengendalian HIV di Indonesia.

\subsection{Metode Analisis Kebijakan}

Pendekatan utama yang digunakan adalah metode narrative review. Penelusuran dokumen kebijakan (di tingkat nasional maupun regional) dan program dilakukan secara tidak terstruktur dengan lebih menekankan pada pengetahuan dan jejaring terhadap dokumen yang tersedia di tingkat publik. Kajian terhadap dokumen-dokumen yang terkait dengan pengendalian HIV yang berlaku di Indonesia dilakukan untuk mempelajari bagaimana strategi di atas telah atau berpotensi untuk dilakukan di Indonesia dan bagaimana 5 kunci di atas telah dilaksanakan.

Dalam melakukan penelusuran dokumen terkait pengendalian HIV di Indonesia, untuk mengkerucutkan pencarian dokumen, secara spesifik sistematika yang dilakukan meliputi:

1. menyasar ke website Sistem Informasi HIV dan IMS (SIHA) yang dikelola oleh Kementerian Kesehatan Republik Indonesia untuk mendapatkan dokumen perundangan terkait pengendalian HIV, dan dokumen laporan terkait epidemi.

2. menyasar website Kementerian Kesehatan Republik Indonesia yang berkaitan dengan pemberdayaan masyarakat

3. selanjutnya, menggunakan daftar dasar hukum yang tertera dalam dokumen Rencana Aksi Nasional Pengendalian HIV (RAN) tahun 2015-2019 dan

4. RAN tahun 2020-2024 dari Kementerian Kesehatan.

Dari website SIHA, diperoleh 34 dokumen kebijakan terkait pengendalian HIV, yang selanjutnya berdasarkan relevansinya dengan peran komunitas dalam SKN hanya 15 dokumen yang ditelaah lebih lanjut. Dari RAN tahun 2015-2019 diperoleh 78 dokumen dan 33 dokumen dari RAN tahun 2020-2024. Dokumen-dokumen hasil penelusuran tersebut kemudian dianalisis berdasarkan relevansinya dengan 3 upaya analisis tersebut di atas. Ada 1 kebijakan tentang pemberdayaan masyarakat bidang kesehatan yang juga diperoleh dari website Kementerian Kesehatan. 


\subsection{Hasil Analisis Kebijakan}

Salah satu faktor utama suksesnya upaya penganggulangan HIV di suatu negara adalah keberadaan kebijakan, peraturan perundangan dan pelaksanaannya. Hambatan hukum dalam regulasi nasional maupun daerah, kebijakan yang kontraproduktif terhadap pengendalian HIV perlu didiskusikan dan ditangani secara serius. Pada bagian ini akan dideskripsikan dan dinilai daya dukung kebijakan dan regulasi kesehatan terkait upaya pencegahan maupun perawatan, dukungan, dan pengobatan (PDP) HIV untuk mengakhiri epidemi HIV pada 2030.

Secara konsisten dari tahun ke tahun, negara telah mengupayakan dukungan dan kepastikan hukum bagi upaya pencegahan penularan HIV. Berdasarkan daftar landasan hukum pengendalian HIV di Indonesia yang tercantum dalam RAN tahun 2020-2024 serta sumber lainnya, setidaknya terdapat 32 kebijakan terkait pengendalian HIV. Di antaranya terdapat 16 dasar hukum yang melandasi program nasional terkait pencegahan HIV, seperti dapat dilihat pada lampiran 2. Terlepas dari komitmen pemerintah dalam upaya pengendalian HIV di Indonesia seperti tertuang pada dokumen kebijakan terkait, hambatan hukum yang bersifat kontraproduktif tetap dapat ditemukan. Lebih jauh akan dipaparkan pada bagian berikutnya dari laporan ini. Di sisi lain, dari berbagai modalitas yang ada untuk pengendalian HIV, walaupun secara global telah banyak studi yang mendukung efektivitas profilaksis pra pajanan HIV atau lebih dikenal dengan PrEP untuk pencegahan penularan HIV, penggunaannya belum diatur di Indonesia. Sebagai upaya tambahan pencegahan penularan HIV, berdasarkan hasil studi internasional maupun nasional, kajian penerapan PrEP di Indonesia sebelum penerbitan kebijakan yang bersesuaian sangat penting untuk dilakukan.

Di antara dasar hukum yang terkait pengendalian HIV, setidaknya terdapat 21 dasar hukum yang melandasi pelaksanaan PDP HIV di Indonesia, seperti dapat dilihat pada lampiran 3. Melalui diundangkannya kebijakan tersebut pemerintah Indonesia telah menunjukkan komitmennya dalam pelaksanaan PDP di Indonesia. Selain yang tersebut, terdapat juga dokumen pedoman ART yang diatur melalui PMK Nomor 87 tahun 2014, di mana viral load sangat dianjurkan diperiksa untuk penentuan kesuksesan terapi. Dalam kaitannya dengan pencapaian target 90-90-90, untuk dapat memperoleh data surveilans dengan cakupan nasional pada 90 yang ketiga, diperlukan kebijakan tertentu yang dapat mendukung upaya pemeriksaan viral load secara berkala di fasilitas layanan kesehatan di seluruh Indonesia. Namun demikian, tanpa didukung oleh sumber daya yang jelas dan berkelanjutan, kebijakan semacam ini dapat mengalami kendala dalam pelaksanaannya.

\subsubsection{Potensi Hambatan Hukum}

Pada bagian diindentifikasi hambatan hukum akibat ketiadaan dukungan kebijakan maupun regulasi yang dapat menghambat akses dan pemberdayaan komunitas untuk memanfaatkan dan mendorong pemanfaatan layanan kesehatan terkait pencegahan dan PDP HIV. Dalam konteks pengendalian HIV, stigma dan diskriminasi adalah faktor yang sangat penting, sehingga sangat rasional untuk dikatakan bahwa segala kebijakan yang menyuburkan atau tidak menjamin non-stigmatisasi dan non-diskriminasi 
berpotensi menciptakan hambatan terhadap pemberdayaan dan akses ke layanan pencegahan dan PDP HIV. Menggaungkan kembali laporan yang pernah diterbitkan oleh Lembaga Bantuan Hukum Masyarakat ${ }^{62}$, berikut ini adalah beberapa ketentuan yang berpotensi dapat menghambat upaya pengendalian HIV di Indonesia yang dikategorikan berdasarkan kerangka pikir layanan HIV yang digunakan dalam studi ini.

\section{Pencegahan Dan Layanan Perubahan Perilaku}

Walaupun kegiatan menjajakan seks tidak diatur pelarangannya secara eksplisit dalam perundangan di Indonesia, tetap ada temuan terkait kriminalisasi pekerja seks menggunakan pasal tidak langsung. Kriminalisasi pekerja seks lebih sering dilakukan menggunakan pasal 505 Kitab Undang-Undang Hukum Pidana (KUHP): menggelandang, tertuju kepada pekerja seks yang menawarkan jasanya di jalanan. Peraturan Daerah (Perda) yang mengkriminalisasi secara langsung pekerja seks, di antaranya Perda Kota Palembang Nomor 2/2004, Perda Kota Banjarmasin Nomor 3/2010, Perda Indramayu Nomor 4/2001, Perda Kota Denpasar Nomor 1/2015, Perda Bogor Nomor 8/2005, Perda Lampung Nomor 15/2002. Kriminalisasi terhadap pekerja seks meningkatkan relaktansi untuk mengakses layanan kesehatan termasuk layanan pencegahan dan PDP HIV. Ditambah dengan kerentanan mereka tentang posisi tawar yang tidak setara dengan klien dalam hal penggunaan kondom dan perilaku seks yang aman, upaya pencegahan penularan HIV menjadi semakin sulit dilakukan dalam perspektif ini. Di lain pihak, pembubaran lokalisasi juga berdampak pada makin sulitnya menjangkau populasi ini untuk terlibat dalam upaya pengendalian HIV. Bahkan mobilisasi pekerja seks dalam rangka penjangkauan pelayanan pemeriksaan kesehatan terkait HIV oleh petugas kesehatan dan penjangkau, harus dibubarkan dan layanannya dihentikan karena razia penegakan Perda terkait. Proses kriminalisasi dan penegakan peraturan yang semacam ini dapat menghambat upaya pengendalian HIV di masyarakat.

Selanjutnya tentang identifikasi diri sebagai penyuka sesama jenis, dan transgender, tidak ada perundangan nasional di Indonesia yang mengatur secara eksplisit pelarangan praktik seksual berdasarkan orientasi seksual LSL. Akan tetapi penolakan terhadap populasi kunci ini dapat terwakili pada Undang-Undang (UU) Pornografi Nomor 44/2008 pasal 4 ayat 1 yang menyebutkan persenggamaan yang menyimpang, yang dalam bagian penjelasan menyebutkan bahwa persenggamaan yang menyimpang mencakup homoseksual, anal seks, oral seks, dan lesbian. Lebih lanjut penggunaan UU Nomor 18/2014 tentang kesehatan jiwa untuk berperkara dengan populasi kunci ini sebagai orang dengan masalah kejiwaan (ODMK) kurang tepat, karena siapapun dengan persoalan berat berpotensi untuk memiliki risiko gangguan jiwa, tidak hanya kaum pada populasi kunci ini. Terlepas dari ketidakberadaan perundangan nasional yang mengatur larangan praktik homoseksualitas, Perda Kota Palembang Nomor 2/2004 mengisyaratkan bahwa homoseksual sebagai bagian dari pelacuran, walaupun dalam praktiknya belum ada kasus pasangan homoseksual yang diperkarakan terkait pelanggaran terhadap Perda ini. Walaupun kriminalisasi secara langsung dan eksplisit dikarenakan orientasi seksual seseorang tidak dimungkinkan berdasarkan perundangan, 
namun kriminalisasi pada populasi kunci ini lebih sering terlaporkan dalam kasus keterlibatan dalam aktivitas sebagai pekerja seks yang terjaring melalui razia.

Lebih lanjut tentang status ODHIV, tidak ada peraturan perundangan nasional yang dapat memperkarakan ODHIV yang tidak ingin mengungkapkan statusnya (buka status). Bahkan upaya merahasiakan status kesehatan pasien dilindungi oleh UU Rahasia Kedokteran. Kriminalisasi transmisi HIV pada tataran tertentu dianggap dapat berkontribusi pada pencegahan transmisi HIV. Namun pada kenyataannya, Perda ini pun membuka celah bagi populasi kunci untuk enggan memeriksakan status HIV-nya secara rutin karena takut akan kriminalisasi ini. Peraturan semacam ini juga dapat memunculkan rasa percaya diri semu pada masyarakat bahwa hukum peraturan perundangan telah cukup memberikan perlindungan dari kemungkinan tertular HIV dan lalai untuk melakukan tindakan pencegahan yang wajib dilakukan supaya tidak tertular. Kriminalisasi transmisi HIV, melipatgandakan stigma dan diskriminasi bagi ODHIV apalagi yang termasuk dalam populasi kunci tertentu yang pada akhirnya dapat melemahkan upaya pengendalian HIV di Indonesia. Walaupun mungkin belum ada ODHIV yang terpidanakan terkait transmisi HIV atau menolak buka status, namun dengan adanya peraturan yang secara formal dan materiil ada, kriminalisasi ini berpotensi untuk terjadi.

\section{Diagnosis Tepat Dan Cepat Termasuk Skrining Berbasis Komunitas dan Metode Lainnya}

PMK Nomor 74/2014 tidak membenarkan tes mandatori HIV untuk memaksa orang melakukan tes tanpa menerima informasi yang adekuat sebelumnya. Hal ini berlaku juga bagi pemeriksaan ibu hamil, calon pengantin, calon TNI, maupun warga binaan lapas. Tes mandatori HIV dapat berarti bahwa institusi tertentu memiliki akses ke hasil tes yang bersangkutan. Hal ini tentu bertentangan dengan peraturan mengenai rahasia kedokteran. Bahkan, PMK ini menyiratkan bahwa prinsip kerahasiaan dalam tes HIV sukarela tidak mutlak berdasarkan persyaratan tertentu, dan pasangan seks dapat diberitahu tentang status HIV pasangannya oleh konselor atau petugas kesehatan. Berlawanan dengan UU Nomor 29 tahun 2004 pasal 45 tentang praktik kedokteran tentang pengungkapan status tanpa persetujuan orang yang bersangkutan. Hak asasi ODHIV tetap perlu ditegakkan dengan menegaskan pasal 45 dalam PMK Nomor 74/2014 begitu juga semua Perda terkait rahasia diagnosa pasien, dan pengecualian prinsip kerahasiaan.

Tentang pemeriksaan status HIV pada anak-anak, lebih jauh, PMK Nomor 74/2014 menyatakan anak di bawah usia 18 tahun kecuali sudah menikah belum memiliki hak untuk membuat atau memberikan persetujuan, hak tersebut teralihkan kepada orang tua, wali, maupun pengampu. Konsekuensinya, populasi kunci (termasuk pelaku prostitusi, pengguna narkotika, warga binaan pemasyarakatan, maupun penyuka sesama jenis) yang berada di bawah umur dan belum menikah tidak bisa datang ke fasilitas layanan kesehatan untuk memeriksakan status HIV-nya tanpa didampingi oleh orang tua/wali/pengampunya. Tidak jarang, walaupun pemeriksaan status HIV terhadap populasi ini dilakukan untuk kepentingan pencegahan penularan HIV, hasilnya tidak dilaporkan secara resmi melalui kanal resmi negara. Pada akhirnya, hal ini dapat menimbulkan penyangkalan keberadaan 
permasalahan HIV pada populasi ini, sehingga kebijakan yang sesuai tidak bisa diterbitkan karena kurangnya dukungan data.

\section{Manajemen Klinis Termasuk Layanan Dukungan Diagnostik dan Dukungan Memulai ART}

Pemeriksaan viral load dan skrining eligibilitas ART ditanggung secara tidak seragam di seluruh Indonesia. Seperti telah disampaikan sebelumnya, PMK Nomor 87/2014 menganjurkan pemeriksaan viral load untuk memeriksa kegagalan terapi ART, tapi tidak mewajibkannya. Walaupun upaya penyelenggaraan Bulan viral load HIV pada Juli hingga Desember 2020 telah dilakukan, namun hingga

September 2020 baru 14\% ODHIV dengan ART yang telah terjaring. ${ }^{63} \mathrm{Hal}$ ini mengisyaratkan perlunya ketetapan hukum yang memungkinkan dilakukannya pemeriksaan viral load secara reguler di seluruh PDP di semua provinsi di Indonesia.

PMK Nomor 51/2013, tentang layanan rujukan PPIA hanya berdasarkan tunjukan dari Kemenkes. Penyedia layanan PPIA adalah fasilitas layanan kesehatan yang telah ditunjuk oleh Kemenkes. Memberikan celah penolakan bagi ibu hamil dengan HIV oleh fasilitas yang tidak ditunjuk, yang pada akhirnya dapat menghambat bahkan mempersulit akses ibu hamil dengan HIV tersebut ke layanan kesehatan yang diperlukannya. Tidak jarang, bahwa fasilitas layanan kesehatan milik pemerintah yang ditunjuk tidak tersebar merata di seluruh wilayah provinsi. Lebih jauh lagi, hal ini dapat memungkinkan beban layanan yang tidak adekuat antara kemampuan layanan yang telah ditunjuk tersebut dan jumlah yang harus dilayani.

\section{Dukungan Mulai ART, Retensinya, Manajemen Mandiri, dan Dukungan Sebaya}

Hambatan yang pertama tentang pengecualian cakupan layanan kesehatan untuk gangguan kesehatan yang disebabkan oleh ketergantungan obat dan atau alkohol (UU Nomor 12/2013 tentang Jaminan Kesehatan Nasional - JKN pasal 25 f) walaupun upaya rehabilitasi dari ketergantungan ini tersedia gratis bagi pengguna obat dan atau alkohol yang telah melakukan wajib lapor ke Institusi Penerima Wajib Lapor (IPWL), namun layanan ini belum tersedia merata di seluruh provinsi di Indonesia, terlebih lagi pembiayaannya masih berasal dari Anggaran Pendapatan dan Belanja Negara (APBN) dan perlu integrasi pembiayaannya ke dalam JKN.

Hambatan berikutnya adalah tentang pembayaran Badan Penyelenggara Jaminan Sosial (BPJS) Kesehatan yang harus dilakukan sekaligus untuk jumlah orang seperti tercantum dalam kartu keluarga (KK), hal ini dapat dipandang memberatkan. Salah satu konsekuensinya adalah tunggakan pembayaran karena tidak mampu bayar terlebih lagi dengan dinaikkannya iuran BPJS pada awal 2021 berdasarkan Perpres Nomor 64/2020. Hal ini jika terakumulasi pada sejumlah warga negara tentu dapat menghambat pemasukan negara yang diperlukan untuk pembiayaan program kesehatan nasional.

Selanjutnya tentang proses registrasi BPJS yang mengharuskan kepemilikan Kartu Tanda Penduduk (KTP) dan KK dalam pengurusannya menyebabkan banyaknya anggota populasi kunci yang sering tidak memiliki dokumen kependudukan ini tidak bisa mengurus kepesertaan BPJS-nya. Menjadi pekerja 
seks, waria, penyuka sesama jenis, pengguna narkotika suntik maupun warga binaan pemasyarakatan sering berakibat penolakan dari keluarga yang dapat berujung pada keengganan anggota keluarga untuk memasukkan individu tersebut ke dalam KK. Lebih lanjut, adanya laporan tentang kecenderungan bagi anggota populasi kunci ini untuk pergi dari rumah tanpa berbekal dokumen kependudukan. Tanpa KK, tanpa KTP, keanggotaan BPJS sangat kecil kemungkinan dimiliki, berakibat pada makin terbatasnya akses ke layanan kesehatan, apalagi populasi kunci ini sering pula terhimpit secara ekonomi.

Pengguna narkotika usia anak dapat dipidanakan berdasarkan UU tentang narkotika dan UU Nomor 11/2012 tentang Sistem Peradilan Pidana Anak, bertentangan dengan UU Nomor 35/2014 tentang perlindungan anak di mana pengguna narkotika usia anak dilihat sebagai korban. Pemidanaan anak dapat menghalangi akses mereka ke layanan rehabilitasi.

Dari segi pendanaan, tidak semua program layanan kesehatan HIV di Indonesia termaktub dalam pembiayaan melalui skema JKN. Beberapa dokumen yang ditemukan menyebutkan pembiayaan program HIV untuk pelaporan 2016 berasal dari 3 sumber utama: donor internasional baik bilateral maupun multilateral (26\%), pemerintah pusat dan daerah, termasuk JKN (74\%), dan swasta. ${ }^{62,64}$ Pembelanjaan terbesar pemerintah pusat dan daerah terutama untuk perawatan dan pengobatan (pengadaan obat dan bahan habis pakai). Alokasi dana program HIV paling besar adalah dari sumber non-JKN. Layanan yang ditanggung JKN hanya spesifik diperuntukkan bagi pengobatan infeksi menular seksual (IMS), konsultasi IMS, dan rawat inap untuk infeksi oportunistik dan perawatan HIV di rumah sakit melalui sistem pembayaran Indonesia Case-Based Group (INA-CBG). ${ }^{64}$ Sayangnya karena tidak mungkin untuk menutupi status HIV seseorang di layanan kesehatan (tercantum di rekam medis pasien), jika merujuk ke status HIV pasien yang bersangkutan, karena status HIV yang positif, pasal bahwa BPJS Kesehatan tidak menanggung pasien HIV menyebabkan cakupan JKN terhadap pengobatan Infeksi Oportunistik ini batal dan tidak bisa diaplikasikan. Masalah yang sudah cukup menimbulkan polemik di tingkat layanan, dengan pasien, maupun antar institusi dan profesi kesehatan maupun non kesehatan.62

\section{Dukungan Psikososial Dalam Konteks Lokal/Kultural/Keagamaan}

Pelarangan stigma dan diskriminasi terhadap orang dengan risiko tinggi terhadap penularan HIV (populasi kunci) dan ODHIV melalui PMK Nomor 21/2013 tidak menjamin bahwa mereka tidak akan mengalaminya. Tidak ada jaminan bagi populasi kunci untuk tidak mengalami risiko tersebut, terlebih lagi, tidak ada yang bisa mereka lakukan jika berada dalam posisi ini, sifat punitif dari peraturan hanyalah berupa sanksi, dan lebih sering menempatkan individu tertentu tersebut dalam posisi yang lebih sulit dari sebelum menyampaikan laporan atau keluhan.

\section{Komunikasi Dan Koordinasi Antara Organisasi Penyedia Layanan, Pasien Dan Komunitas/Organisasi Komunitas}

Peraturan Menteri Riset Teknologi dan Pendidikan Tinggi (Permenristekdikti) Nomor 35/2016 tentang Penyelenggaran Profesi Insinyur telah mensyaratkan tes narkotika, begitu juga Peraturan Menteri 
Pendidikan Nasional (Permendiknas) Nomor 66/2009 tentang Syarat Bebas HIV Bagi Peserta Didik Terkait. Terlepas dari detail proses seleksi masuk institusi pendidikan, ekslusi terhadap ODHIV dan pengguna narkotika mengisyaratkan ketidaksetaraan akses ke pendidikan. Keterbatasan hingga ketiadaan akses ini pada akhirnya dapat menempatkan yang terdiskriminasi pada posisi rentan tanpa pendidikan, yang krusial untuk meningkatkan kualitas hidup mereka, dan lebih jauh membuka kemungkinan tidak terpenuhinya hak-hak asasi mereka yang lain.

UU Nomor 35/2009 tentang Narkotika memang memberikan peluang pengguna narkotika untuk tidak diproses hukum dengan periode tertentu jika mengakses layanan rehabilitasi melaui proses wajib lapor ke IPWL. Akan tetapi, pada praktiknya, tetap ada laporan tentang pengguna narkotika yang dipidanakan walaupun sudah melaksanakan wajib lapor. Dengan adanya fakta semacam ini, dapat dipahami jika pengguna narkotika memilih menutup diri dan enggan untuk mengakses layanan kesehatan, bahkan ketika keinginan dan kesadaran untuk merehabilitasi diri muncul. Pada kondisi ini peran komunitas sangat penting untuk memberikan solusi, pendampingan, hingga advokasi.

Upaya dekriminalisasi pengguna narkotika telah diundangkan melalui Surat Edaran Mahkamah Agung (SEMA) 4/2010 untuk populasi umum, Peraturan Mahkamah Agung (Perma) 4/2014 untuk populasi anak, maupun Peraturan Bersama Nomor 1/PB/MA/III/2014 tentang Rehabilitasi Pengguna Narkotika. Dalam kebijakan dekriminalisasi ini, pengguna narkotika berdasarkan keputusan hakim di akhir proses peradilan memiliki peluang terdiversi dari hukuman kurungan dan untuk mengakses layanan rehabilitasi. Berdasarkan Perber Rehabilitasi, akses ke rehabilitasi tidak serta merta menghentikan proses hukum. Tiap temuan kasus akan dinilai untuk kelayakan pemrosesan proses hukum terlepas, memungkinkan pengguna narkotika yang bukan pengedar untuk dapat langsung mengakses layanan rehabilitasi tanpa melalui seluruh proses persidangan. Praktik yang sedikit banyak memunculkan potensi korupsi melalui transaksi perkara apabila pelaksanaannya tidak disertai dengan komitmen yang kuat dari penegaknya.

Peraturan Menteri Sosial (Permensos) Nomor 22/2014 tidak mengatur kebutuhan medis bagi penerima rehabilitasi sosial. Lebih lanjut Permensos tersebut belum terintegrasi dengan program pengendalian HIV. Fakta ini memperlihatkan adanya celah terjadinya putus obat bagi pekerja seks yang terjaring dan harus bermalam di dinas sosial dan tidak mendapat akses ke ART-nya. Dalam proses penegakan Perda melalui razia pun, tidak jarang pekerja seks mengalami kekerasan fisik maupun mental.

Secara umum, seperti telah ditegaskan di atas, segala kebijakan yang berpotensi menyuburkan stigma dan diskriminasi terhadap populasi risti dan ODHIV sangat berpotensi menghambat upaya pengendalian HIV di Indonesia. Karena pengalaman negatif tersebut sangat berkontribusi terhadap relaktansi untuk secara nyaman mengakses layanan pencegahan dan PDP HIV. Apalagi dengan adanya pemahaman bersama bahwa kunci pencegahan penularan HIV adalah tingkat kesadaran masyarakat yang tinggi terutama populasi kunci untuk melakukan pemeriksaan status HIV, dan ODHIV untuk mengakses layanan PDP secara berkala. Karenanya untuk meningkatkan kualitas dan kuantitas akses

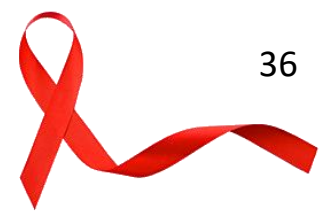


ke layanan pencegahan dan PDP HIV di Indonesia oleh populasi kunci dan ODHIV, segala ketentuan dan pelaksanaannya yang menyuburkan terjadinya praktik stigmatisasi dan diskriminasi perlu ditinjau dan dikaji kembali.

\subsubsection{Penilaian Kinerja SKN Dalam Pengendalian HIV di Indonesia}

Respon pengendalian HIV di Indonesia sampai saat ini masih berjalan dengan menggunakan pendekatan vertikal, meskipun tata kelola pemerintahan sudah terdesentralisasi. Pendekatan vertikal pada program pengendalian HIV terjadi sejak awal masuknya HIV di Indonesia sebagai bentuk respon darurat. Saat ini, situasi epidemi sudah bergeser. Respons pengendalian HIV seharusnya sudah beralih menggunakan pendekatan horizontal, yang mengedepankan kebutuhan daerah serta menjaga keberlangsungannya. Namun hal ini belum terjadi, ditunjukkan dari pengalaman daerah dalam menyikapi pengendalian HIV yang masih cenderung menunjukkan pendekatan vertikal, seperti rencana strategi daerah provinsi tentang pencegahan HIV dimasukkan dalam Rencana Pembangunan Jangka Menengah Daerah (RPJMD) kabupaten/kota.

\section{Pendanaan Pengendalian HIV Secara Nasional}

Pembiayaan program HIV oleh pemerintah dilakukan melalui skema APBN, APBD, maupun JKN. Pemda menerima dana dari pemerintah pusat yang menjadi bagian APBD bersama dengan pendapatan asli daerah. ${ }^{64}$ Dana transfer dapat mencakup dana alokasi khusus untuk infrastruktur fisik dan biaya operasional non-fisik, juga dana dekonsentrasi, dan bantuan teknis dan pelatihan. Dana alokasi nonfisik dapat digunakan untuk pencegahan dan pengobatan HIV, sedangkan dana dekonsentrasi dapat digunakan untuk promosi kesehatan, kegiatan yang berkaitan dengan upaya mencapai cakupan kesehatan universal. Pendapatan asli daerah juga dapat dipakai untuk mencapai cakupan universal tersebut dan juga program kesehatan prioritas di masing-masing daerah. Pemerintah pusat membiayai pengadaan ART dan bahan habis pakai sekitar 88\% pada 2015 dan 93\% pada 2016 dari keseluruhan belanja pemerintah pusat untuk program pengendalian HIV. ${ }^{64}$ JKN tidak menanggung pembiayaan ART sesuai Perpres Nomor 82/2018, yang menyatakan bahwa intervensi/pengobatan yang sudah ditanggung program lain tidak akan ditanggung oleh JKN. Lebih lanjut, sebelum terbitnya Perpres ini, pelimpahan tanggung jawab penyediaan ART gratis ke pemerintah pusat telah berjalan sejalan denngan Kepmenkes Nomor 1190/2004.64

Beberapa kategori obat dapat dibayar di rumah sakit di luar tarif INA-CBG, termasuk obat-obatan yang diperlukan untuk perawatan pasien dengan penyakit kronis tertentu sesuai Surat Edaran (SE) Menteri Kesehatan Nomor 32/2014. Berkenaan dengan SE ini, Kemenkes dapat berupaya untuk memasukkan paduan ART ke dalam kategori obat penyakit kronis, karena ODHIV dengan ART akan perlu mengkonsumsi ART seumur hidup. Melalui kanal ini, fasilitas layanan kesehatan dapat membeli ART dan memperoleh penggantian dari BPJS berdasarkan klaim INA-CBG. Namun ini masih tataran ide, ${ }^{64}$ dan untuk implementasinya, kajian khusus perlu dilakukan. 
Pembiayaan rawat inap dan rawat jalan untuk ODHIV sesuai dengan PMK Nomor 52/2016, yang mengacu pada INA-CBG (PMK Nomor 59/2014). Selanjutnya mengenai pemeriksaan viral load, tindakan ini ditanggung oleh JKN sebagai bagian dari layanan rawat inap saja. Skema pembiayaan program layanan HIV lain yang dirasa belum adekuat adalah pembiayaan untuk program harm reduction bagi para pengguna narkotika suntik (penasun), maupun mereka yang telah mengaskses Program Rumatan Terapi Metadon (PRTM). Pembiayaan ini sulit dilakukan dengan menggunakan skema JKN, karena JKN tidak memungkinkan pembiayaan perawatan penyakit yang disebabkan oleh ketergantungan obat (sesuai Perpres Nomor 19/2016, pasal 25.)

Pengintegrasian pembiayaan pengendalian HIV secara sepenuhnya ke dalam JKN penting untuk memastikan bahwa negara menjamin layanan kesehatan untuk pencegahan HIV dan terapinya secara berkelanjutan. Mengingat besarnya porsi pembiayaan melalui pendanaan internasional yang mencapai $46 \%$ di tahun $2015^{62}$, dan $26 \%$ di $2016^{64}$ potensi hilangnya akses ke layanan pencegahan dan terapi HIV bagi masyarakat utamanya bagi populasi kunci dan ODHIV yang diakibatkan oleh kemungkinan dicabutnya pendanaan dari institusi internasional sangat perlu diantisipasi. Karenanya sangat diharapkan agar pemerintah segera membuat rancangan yang terarah dan terukur untuk memastikan integrasi semua layanan kesehatan terkait HIV ke dalam JKN dengan tetap memperhatikan karakteristik tertentu dari upaya pengendalian HIV.

\section{Penyediaan Layanan Kesehatan Terkait Pencegahan dan PDP HIV}

Penyediaan layanan kesehatan terkait pencegahan dan PDP HIV di Indonesia disediakan oleh pemerintah Pusat dan daerah. Layanan yang disiapkan pemerintah dalam pencegahan dan PDP HIV adalah penyediaan layanan penyuluhan terkait IMS dan penyediaan kondom oleh tenaga kesehatan salah satunya Bidan (PMK Nomor 1464/Menkes/Per/X/2010 tentang Izin dan Penyelenggaraan Praktik Bidan). Layanan lainnya yang perlu disiapkan adalah laboratorium klinik yang harus diselenggarakan secara baik dengan memenuhi kriteria organisasi, ruang dan fasilitas, peralatan, bahan, spesimen, metode pemeriksaan, mutu, keamanan, pencatatan dan pelaporan (PMK Nomor 43/2013 tentang Cara Penyelenggaraan Laboratorium Klinik yang Baik). Pemerintah bertanggung jawab memenuhi ketersediaan dan kebutuhan yang sangat mendesak obat Antiviral dan Antiretroviral untuk pengobatan penyakit Human Immunodeficiency Virus-Acquired Immuno Deficiency Syndrome (HIV/AIDS) dan Hepatitis B (PerPres Nomor 76 tahun 2012 tentang Pelaksanaan Paten Oleh Pemerintah Terhadap Obat Antiviral dan Antiretroviral). Pemerintah dan pemerintah daerah bertanggung jawab juga terhadap pelayanan darah yang aman, mudah diakses, dan sesuai dengan kebutuhan masyarakat.

\section{Pengadaan Sumber Daya, Sarana dan Prasarana Nasional dan Regional Terkait Pengendalian HIV}

Pemerintah, Pemerintah Daerah, dan Fasilitas Pelayanan Kesehatan bertanggung jawab terhadap pendanaan penyelenggaraan Sistem Informasi Kesehatan. Informasi Kesehatan terdiri atas informasi upaya kesehatan; informasi penelitian dan pengembangan kesehatan; informasi pembiayaan kesehatan; informasi sumber daya manusia kesehatan; informasi sediaan farmasi, alat kesehatan, dan

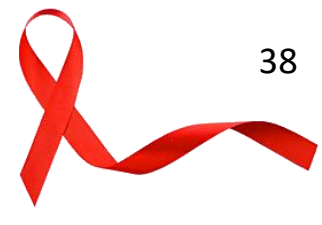


makanan; informasi manajemen dan regulasi kesehatan; dan informasi pemberdayaan masyarakat. Dana kapitasi JKN di Fasilitas Kesehatan Tingkat Pertama (FKTP) dimanfaatkan seluruhnya untuk jasa pelayanan kesehatan dan dukungan biaya operasional pelayanan kesehatan. Pendanaan yang berkaitan dengan kegiatan penyusunan, penetapan, pelaporan, monitoring dan evaluasi, pembinaan dan pengawasan, pembangunan sistem dan atau sub-sistem informasi manajemen, serta pengembangan kapasitas untuk mendukung penyelenggaraan Standar Pelayanan Minimal (SPM) Bidang Kesehatan yang merupakan tugas dan tanggung jawab pemerintah, dibebankan kepada APBN Kementerian Kesehatan.

Pemerintah daerah tingkat provinsi maupun kabupaten/kota bertanggung jawab untuk mengkoordinir dan menyelenggarakan program pengendalian HIV, mengatur sistem informasi pencatatan, pelaporan dan evaluasi, menetapkan situasi HIV di tiap daerah, dan memastikan ketersediaan fasilitas layanan kesehatan primer dan rujukan untuk pencegahan dan pengendalian HIV. Pengadaan alat kesehatan dan obat-obatan masih menjadi tanggung jawab pemerintah pusat. ${ }^{64}$ Dapat disampaikan juga bahwa tanggung jawab Pemda berbeda antar beragam kebijakan tentang pengendalian HIV. ${ }^{64}$ Variasi dapat ditemukan antara PMK Nomor 5/2014 dan PMK Nomor 4/2019. SPM bidang kesehatan tidak mencakup pengobatan HIV maupun beberapa komponen program yang disebutkan dalam PMK Nomor 21/2013. Lebih jauh, kewajiban Pemda hanya terbatas pada promosi kesehatan dan skrining HIV. Namun, berdasarkan PMK Nomor 5/2014, walaupun SPM bidang kesehatan untuk daerah tidak mencakup PDP HIV, dan mendukung target kinerja, Pemda masih perlu menyediakan layanan ini di tingkat layanan primer.

\section{Tata Kelola Dan Tata Laksana Pelayanan}

Peraturan di Indonesia menyebutkan dalam hal penyakit menular seperti HIV, Menteri dan Kepala Daerah terlibat dalam pengendalian wabah penyakit menular tersebut. Kesehatan merupakan salah satu pelayanan dasar yang wajib dipersiapkan Pemerintah provinsi dan kabupaten/kota. Pembangunan kesehatan di Indonesia dibentuk dengan tujuan meningkatkan kesadaran, kemauan, dan kemampuan hidup sehat bagi setiap orang agar terwujud derajat kesehatan masyarakat yang setinggi-tingginya, sebagai investasi bagi pembangunan sumber daya manusia yang produktif secara sosial dan ekonomis. Untuk mewujudkan derajat kesehatan yang setinggi-tingginya bagi masyarakat, diselenggarakan upaya kesehatan yang terpadu dan menyeluruh dalam bentuk upaya kesehatan perseorangan dan upaya kesehatan masyarakat.

Pelayanan HIV dilakukan dengan Pemetaan kelompok sasaran; Penyiapan SDM; Promosi/penyuluhan; Jejaring kerja dan kemitraan; Sosialisasi; Pemeriksaan HIV; Rujukan kasus HIV untuk mendapatkan pengobatan ART; Pencatatan dan pelaporan; dan Monitoring dan evaluasi. Upaya Pencegahan HIV dapat dilakukan dengan konseling dan tes HIV. Dalam memberikan pelayanan kesehatan, tenaga kesehatan sudah memiliki kode etik yang memastikan kerahasiaan ODHIV sehingga tidak adanya diskriminasi. BPJS Kesehatan juga membantu pengelolaan dana dalam menyelenggarakan program jaminan kesehatan. 
Dalam pengendalian HIV, terdapat pelaksanaan Paten oleh Pemerintah terhadap obat Antiviral dan Antiretroviral dimaksudkan untuk memenuhi ketersediaan dan kebutuhan yang sangat mendesak obat Antiviral dan Antiretroviral untuk pengobatan HIV dan Hepatitis B. Pengendalian HIV dan AIDS mengintegrasikan dengan program pembangunan di tingkat nasional, provinsi dan kabupaten/ kota; dilakukan secara sistematis dan terpadu; dilakukan oleh masyarakat dan Pemerintah berdasarkan kemitraan; dan melibatkan peran aktif populasi kunci dan ODHIV serta orang-orang yang terdampak HIV dan AIDS.

\section{Faktor Eksternal Di Samping Kelembagaan Maupun Kebijakan Negara Tentang Kesehatan}

Pengendalian HIV tidak melulu merupakan persoalan di bidang kesehatan. Seringkali dalam praktiknya, upaya ini menyentuh bidang kehidupan masyarakat yang lain, di antaranya: bidang pendidikan, ketenagakerjaan, kependudukan, dan pemidanaan. Seperti telah disampaikan sebelumnya pada bagian 3.3.1-4 Dapat dilaporkan bahwa hambatan pemenuhan hak anggota populasi kunci terkait diskriminasi yang dialaminya karena status HIV-nya atau status orang terdekatnya yang termasuk ODHIV, sedikit banyak menghambat aksesnya ke layanan kesehatan. Hal ini dapat menimbulkan relaktansi untuk melakukan pemeriksaan status HIV-nya secara berkala di fasilitas layanan kesehatan. Pada akhirnya, hal semacam inilah yang berpotensi menghambat upaya pengendalian HIV dan selanjutnya upaya pencapaian target 90-90-90 di Indonesia.

\subsubsection{Kebijakan Desentralisasi dan Perannya Dalam Upaya Pengendalian HIV Serta Positioning Layanan Komunitas}

Desentralisasi dapat didefinisikan sebagai pelimpahan kekuasaan dari pusat ke daerah untuk mengatur rumah tangganya sendiri. Perkembangan perundangan tentang pemerintah daerah dalam hal ini tentang desentralisasi dapat dirunut sebagai berikut: UU Nomor 22/1999, UU Nomor 32/2004, UU Nomor 23/2014, UU Nomor 2/2015, hingga UU Nomor 9/2015. UU Nomor 22/1999 mengatur penyelenggaraan pemerintah daerah yang lebih menekankan aspek desentralisasi. UU ini juga melimpahkan kewenangan penuh kepada kabupaten atau kota atau kabupaten tingkat II dan kotamadya untuk menyelenggarakan pemerintahan daerah berdasarkan kewenangan keleluasan untuk membentuk dan melaksanakan kebijakan menurut prakarsa dan aspirasi masyarakat. UU Nomor 22/1999 menghapus hirarki antara pemerintah kabupaten/kota dengan provinsi. UU No.32 tahun 2004 berisi penyerahan tugas dalam urusan wajib dan pilihan. UU Nomor 23/2014 menggeser kewenangan luas untuk kewenangan khusus yang diletakkan pada provinsi dengan maksud bahwa daerah kabupaten/kota menjadi pusat desentralisasi. UU Nomor 2/2015 tentang Penetapan Peraturan Pemerintah Pengganti Undang-Undang (Perpu) No.2/2014 tentang pemerintahan daerah menjadi UU yang menegaskan bahwa pemilihan kepala daerah tetap dilakukan secara demokratis. Selanjutnya, UU Nomor 9/2015 tentang perubahan kedua atas UU Nomor 23/2014 semakin memperkuat dan memperjelas fungsi dan peranan pemerintah daerah.

Selain perundangan tersebut, Rencana Pembangunan Jangka Menengah Nasional (RPJMN) 2005-2025 mengatur pula bagaimana Rencana Pembangunan Jangka Panjang (RPJP) Daerah yang mengacu kepada 
RPJP Nasional, namun bukan untuk membatasi kewenangan daerah, tetapi agar terdapat acuan yang jelas, sinergisitas, dan keterkaitan dari setiap perencanaan pembangunan di tingkat daerah berdasarkan kewenangan otonomi yang dimilikinya berdasarkan platform RPJP Nasional. Pengendalian dan evaluasi pelaksanaan RPJP Daerah dilakukan oleh Kepala Satuan Kerja Perangkat Daerah.

PMK Nomor 43/2016 tentang Standar Pelayanan Minimal (SPM) Bidang Kesehatan merupakan acuan bagi Pemerintah Daerah Kabupaten/Kota dalam penyediaan pelayanan kesehatan yang berhak diperoleh setiap warga secara minimal. Peraturan terakhir yang mengatur tentang pembagian urusan antara Pemerintah Pusat dan Pemerintah Daerah (Pemda) adalah UU Nomor 23/2014 menyebutkan bahwa kesehatan adalah satu dari enam urusan concurrent (bersama) yang bersifat wajib dan terkait dengan pelayanan dasar. Konsep SPM berubah dari Kinerja Program Kementerian menjadi Kinerja Pemda yang memiliki konsekuensi reward dan punishment, sehingga Pemda diharapkan untuk memastikan tersedianya sumber daya (sarana, prasarana, alat, tenaga dan uang/biaya) yang cukup agar proses penerapan SPM berjalan adekuat. SPM merupakan hal minimal yang harus dilaksanakan oleh Pemda untuk rakyatnya, maka target SPM harus 100\% setiap tahunnya.

Kondisi kemampuan sumber daya Pemda di tiap daerah di seluruh Indonesia berbeda dalam melaksanakan keenam urusan tersebut, maka pelaksanaan urusan tersebut diatur dengan SPM untuk memastikan ketersediaan layanan bagi seluruh warga negara. SPM sekurangnya mempunyai dua fungsi yaitu memfasilitasi Pemda untuk melakukan pelayanan publik yang tepat bagi masyarakat dan sebagai instrumen bagi masyarakat dalam melakukan kontrol terhadap kinerja pemerintah di bidang pelayanan publik bidang kesehatan. SPM juga akan berfungsi sebagai instrumen untuk memperkuat pelaksanaan performance-based budgeting. Implementasi SPM akan memperkuat sisi promotif - preventif sehingga diharapkan akan berdampak pada penurunan jumlah kasus kuratif. Capaian kinerja Pemda Kabupaten/Kota dalam memberikan pemeriksaan HIV terhadap orang berisiko terinfeksi HIV dinilai dari persentase orang berisiko terinfeksi HIV yang datang ke fasilitas layanan kesehatan dan mendapatkan pemeriksaan HIV sesuai standar di wilayah kerjanya dalam kurun waktu satu tahun. Target Capaian kinerja Pemerintah Daerah Kabupaten/Kota dalam upaya pemeriksaan HIV terhadap orang berisiko terinfeksi HIV adalah $100 \%$. Desentralisasi ini akan sangat mempengaruhi upaya promotif - kuratif dari pengendalian HIV di seluruh daerah di Indonesia.

Lahirnya Perpres Nomor 75/2006 tentang Komisi Pengendalian AIDS Nasional yang diperkuat dengan Permendagri Nomor 20/2007 tentang Pedoman Umum Pembentukan Komisi Pengendalian AIDS dan Pemberdayaan Masyarakat dalam Rangka Pengendalian HIV di daerah merupakan salah satu bentuk komitmen Kementerian Dalam Negeri untuk mengatasi permasalahan HIV melalui kepemimpinan daerah. Permendagri ini mencantumkan bahwa organisasi Komisi Penanggulangan AIDS (KPA) tingkat provinsi/ kabupaten/kota, memiliki tugas dan tanggung jawab, serta mengatur sumber pendanaan pengendalian HIV dan AIDS di daerah. Pada Desember 2017, Komisi ini dipurnatugaskan berdasarkan Perpres Nomor 124/2016, dan pengalihan tugasnya diestafetkan ke Bidang Pencegahan dan Pengendalian Penyakit (P2P). 
Berkaitan dengan hal tersebut, belum banyak ditemukan laporan tentang kinerja pengendalian HIV di Indonesia sejak purna tugas komisi tersebut. ${ }^{65}$

Desentralisasi menjadi salah satu hal penting yang harus diperhatikan dalam mencapai target 90-90-90 di Indonesia. Sering terjadi tumpang tindih/kurang terpadu atau kekosongan dalam pembagian urusan dalam sistem kesehatan. Desentralisasi juga berdampak pada penerimaan, interpretasi dan pelaksanaan kebijakan dari pemerintah pusat. Untuk program HIV sendiri, penerapan kebijakan pemerintah pusat sering kali diterjemahkan, diterima dan dilaksanakan berbeda-beda di setiap daerah. Kondisi ini juga yang menjadi tantangan pencapaian target 90-90-90. Beberapa contoh tantangan dari desentralisasi yaitu tidak adanya dana yang disediakan pemerintah daerah untuk membuat sistem surveilans yang merupakan dasar menyusun strategi pengendalian suatu penyakit di daerah. ${ }^{66}$ Dilaporkan oleh PKMK FK UGM pada 2009, penentuan target program HIV masih mengacu pada target pusat, padahal seharusnya target dan perencanaan di daerah menyesuaikan dengan situasi epidemi, sumber daya di daerah. ${ }^{67}$

Oleh karena itu, diperlukan pengembangan sistem kesehatan yang harmonis dengan kebijakan desentralisasi untuk meningkatkan status kesehatan masyarakat. Sistem kesehatan nasional (Perpres Nomor 72/2012 pasal 1 angka 2) menggariskan bahwa pengelolaan kesehatan diselenggarakan oleh semua komponen bangsa Indonesia secara terpadu dan saling mendukung guna menjamin tercapainya derajat kesehatan masyarakat yang setinggi-tingginya, serta bersifat berjenjang di pusat dan daerah dengan memperhatikan otonomi daerah dan otonomi fungsional di bidang kesehatan.

Pemerintah pusat perlu merangkul pemerintah daerah untuk bisa memiliki visi yang sama dalam pengendalian HIV. Dengan model desentralisasi perlu dipastikan pemerintah memiliki kesamaan persepsi tentang tujuan program pengendalian HIV sehingga bisa memastikan kebijakan dan panduan yang dikeluarkan oleh pemerintah pusat dilaksanakan dengan patuh di setiap daerah. Perlu usaha untuk membangun kesadaran akan pentingnya isu HIV di tataran pemangku kebijakan baik di tingkat nasional maupun di daerah. Keterpaduan komponen khususnya di daerah sebaiknya juga mengarahkan pada layanan ART dengan mendorong Puskesmas sebagai layanan lini pertama untuk bisa memberikan pengobatan ART untuk secara lebih aktif untuk menjemput bola, dalam hal ini pasien. Selain itu juga memastikan akses klien terhadap pengobatan dan memastikan kepatuhan dalam pengobatan dengan melibatkan komunitas dalam pelaksanaan upaya tersebut.

Secara keseluruhan, desentralisasi di Indonesia dipandang telah berkontribusi terhadap kinerja pengendalian HIV, salah satunya dalam bentuk pengadaan layanan HIV di tiap daerah berdasarkan SPM yang telah digariskan. Namun kinerja yang sudah ada masih dapat ditingkatkan. Di antaranya dengan melakukan pemetaan sumber daya, seperti SDM sebagai aktor yang terlibat, dan termasuk juga sumber daya dana/pembiayaan yang ada tiap daerah untuk program HIV; dan harmonisasi upaya kesehatan nasional dan daerah dengan kebijakan desentralisasi dalam kaitannya dengan upaya khusus pencapaian target 90-90-90. 


\subsection{Identifikasi Positioning Layanan Komunitas Terkait Pengendalian HIV}

Untuk memberikan dampak kesehatan yang optimal, positioning komunitas dalam upaya pengendalian HIV harus sejalan dengan strategi pembangunan nasional bidang kesehatan. Walaupun tidak disebutkan secara eksplisit, peran dan posisi komunitas dalam upaya promosi kesehatan termasuk dalam upaya pengendalian HIV telah banyak disinggung dan diterjemahkan dalam berbagai dokumen kebijakan dan strategi nasional tentang penggulangan HIV. Lampiran 2 menunjukkan beberapa dokumen kebijakan dan strategi nasional yang terkait dengan upaya pengendalian HIV, yang sedikit banyak menyinggung peran dan posisi komunitas dalam upaya tersebut, yang berhasil diidentifikasi dan dianalisis.

UU Nomor 36/2009 merupakan implementasi dari paradigma sehat yang mengutamakan upaya promotif, dan preventif tanpa mengabaikan kuratif dan rehabilitatif, yang dipandang perlu diterbitkan sebagai respon dari perkembangan ketatanegaraan dari sentralisasi menjadi desentralisasi di mana seluruh aspek di bidang kesehatan sepenuhnya diserahkan kepada masing-masing daerah, tantangan era globalisasi, dan semakin kompleksnya permasalahan kesehatan. Sejalan dengan hal tersebut, sistem kesehatan nasional (SKN) Indonesia menjelaskan bahwa pengelolaan kesehatan diselenggarakan oleh semua komponen bangsa Indonesia secara terpadu dan saling mendukung guna menjamin tercapainya derajat kesehatan masyarakat yang setinggi-tingginya.

Komponen SKN yang pertama yaitu upaya kesehatan dalam pelayanan HIV yaitu upaya promotif hingga rehabilitatif yang dilakukan secara terpadu yang tentunya dilakukan dengan kolaborasi penyedia layanan dan penguatan peran komunitas agar upaya yang dimulai dari peningkatan perilaku hidup sehat, pencegahan penyakit, pengobatan, perawatan dan dukungan bagi ODHIV serta orang-orang terdampak HIV, termasuk orang yang hidup dengan ODHIV, dapat berjalan secara efektif.

Komponen kedua dari SKN di bidang HIV dalam dokumen disebutkan bahwa pentingnya inovasi atau terobosan ilmu pengetahuan dan teknologi yang etis dan terbukti bermanfaat dalam penyelenggaraan pembangunan kesehatan secara luas, termasuk penguatan sistem rujukan. Sistem rujukan erat kaitannya juga dengan adanya jejaring baik dari komunitas di level daerah hingga level pemerintahan nasional dan terintegrasi secara harmonis.

Komponen ketiga yaitu pembiayaan kesehatan. Dilihat dari aspek upaya pencegahan maupun perawatan, dukungan, dan pengobatan (PDP) yang tercantum dalam beberapa dokumen/kebijakan dapat dilihat pentingnya meningkatkan pembiayaan pengendalian HIV dan menyesuaikannya dengan seluruh langkah pengendalian HIV, di antaranya mencakup: pemetaan kelompok sasaran; penyiapan sumber daya manusia (SDM); promosi/penyuluhan; jejaring kerja dan kemitraan; sosialisasi; pemeriksaan HIV; rujukan kasus HIV untuk mendapatkan pengobatan ART; pencatatan dan pelaporan; dan monitoring dan evaluasi. Pembiayaan ini juga perlu dipetakan sumber-sumber pembiayaannya.

Komponen keempat yaitu SDM kesehatan yang perlu dipersiapkan, di antaranya dokter spesialis sesuai kewenangannya, dokter/dokter gigi di FKTP, Fasilitas Kesehatan Tingkat Lanjut (FKTL), dan lapas/rutan yang terlatih dalam bidang HIV; tenaga kesehatan sebagai konselor HIV di FKTP, FKTL dan lapas/rutan

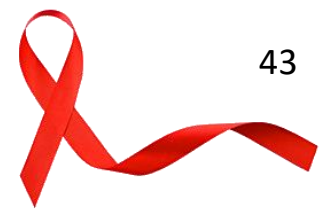


yang terlatih dalam bidang HIV; pranata laboratorium kesehatan di Puskesmas dan RSUD yang terlatih tentang pemeriksaan HIV; petugas pencatatan dan pelaporan/rekam medis yang terlatih di bidang pencatatan dan pelaporan HIV dan IMS; pengelola program HIV dan IMS di Kabupaten/Kota; sumber daya manusia yang memiliki kompetensi di bidang epidemiologi; dan juga melibatkan komunitas populasi kunci dan ODHIV serta orang-orang yang terdampak HIV.

Komponen kelima adalah sediaan farmasi, alat kesehatan, dan makanan yang dalam upaya PDP HIV yang diperlukan adalah, lancet, reagen anti HIV, termasuk juga pemeriksaan HIV mandiri (self testing kit) yang merata pada seluruh daerah dan jumlah yang cukup, dan obat ART yang dapat dibantu komunitas untuk pendistribusiannya kepada ODHIV secara etis berdasarkan pedoman ditetapkan.

Komponen selanjutnya dalam SKN adalah manajemen, informasi, dan regulasi kesehatan yaitu dengan adanya integrasi antar regulasi untuk mencapai target 90-90-90 dan mengakhiri pandemi tahun 2030 serta adanya sistem informasi pelayanan HIV terintegrasi secara nasional menggunakan register SIHA, dengan harapan dapat meningkatkan manajemen pengendalian HIV yang lebih akuntabel, transparan, terukur, terintegrasi, berdayaguna, dan berhasilguna.

Komponen akhir dari SKN adalah pemberdayaan masyarakat. Dalam SKN telah ditunjukkan bagaimana peran dan posisi komunitas dalam upaya pencegahan maupun PDP untuk mencapai target 90-90-90 dan mengakhiri pandemi tahun 2030, yaitu bahwa setiap kebijakan yang terkait memberikan posisi keterlibatan komunitas dalam (1) upaya promosi kesehatan; (2) mengelola dan memberikan pelayanan, termasuk di fasilitas yang berbasis layanan klinis maupun fasilitas yang tidak berbasis klinik seperti edukasi sebaya, peningkatan kesadaran, PDP berbasis komunitas, dan layanan sosial lainnya; (3) memberikan dukungan kepada kelompok masyarakat yang terpinggirkan dan terdiskriminasi untuk memanfaatkan pelayanan kesehatan; (4) mobilisasi aksi kelompok masyarakat marjinal atau terdiskriminasi untuk memperbaiki kondisi sosial termasuk akses ke pelayanan kesehatan yang lebih baik; (5) menyasar determinan kesehatan yang lebih luas termasuk ketidaksetaraan gender dan hak asasi manusia (HAM), melakukan kegiatan advokasi pada kebijakan dan aturan hukum yang mendukung upaya pengendalian HIV; dan (6) monitoring dan advokasi bagi perlindungan HAM yang lebih baik dan akses yang baik ke pelayanan kesehatan.

Tidak dapat dipungkiri, peran organisasi masyarakat sipil (LSM dan organisasi kemasyarakatan lainnya) dalam hal penjangkauan dan pencegahan HIV di Indonesia sangat signifikan. Namun demikian, PMK Nomor 21/2013 tidak menjamin dukungan keuangan untuk program penjangkauan dan pencegahan HIV oleh CSO ini. ${ }^{64}$ Kewajiban pemerintah terkait hal tersebut hanya terbatas pada anjuran untuk penyediaan alokasi anggaran (pasal 48) tanpa berkewajiban untuk secara aktif bermitra dengan LSM (pasal 49). ${ }^{64}$ Selain pendanaan melalui pendanaan pemerintah, LSM dapat menerima dananya melalui mekanisme hibah maupun bantuan sosial dari pemerintah pusat maupun daerah. Sayangnya mekanisme hibah ini hanya dapat mengkontrak individu dan bukan LSM sebagai organisasi secara keseluruhan.

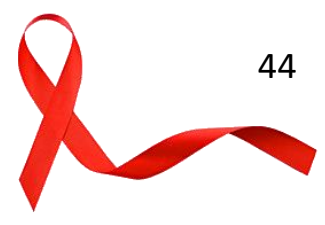


Lebih lanjut berdasarkan PMK No.8/2019 anggota masyarakat yang terlibat dalam kegiatan pemberdayaan masyarakat atau disebut kader kesehatan didefinisikan sebagai setiap orang yang dipilih oleh masyarakat dan dilatih untuk menggerakkan masyarakat berpartisipasi dalam pemberdayaan masyarakat bidang kesehatan. Kader ini bertugas dalam wilayah desa/kelurahan dan mendapat pelatihan dari pemerintah serta bekerja dalam kerangka Upaya Kesehatan Berbasis Masyarakat (UKBM). Pendefinisian kader kesehatan ini tidak sesuai dengan konteks pengendalian HIV dimana tenaga penjangkau lapangan dan pendamping komunitas umumnya bekerja di dalam sebuah LSM atau organisasi kemasyarakatan lainnya bahkan juga di bawah kendali KPAD. Mereka ini tidak dipilih oleh masyarakat atau komunitas berbasis wilayah, bahkan banyak diantaranya bekerja secara bekerja secara profesional dan mendapat upah yang sesuai dengan aturan ketenagakerjaan. Perbedaan definisi ini membuat penggunaan istilah kader kesehatan pada komunitas yang bekerja dalam pengendalian HIV menjadi sulit.

Meskipun demikian, dalam PMK yang sama, dibahas juga tenaga pendamping yang memiliki tugas katalisator, penyedia dukungan, penghubung dengan sumber daya yang dapat dimanfaatkan, pendamping dalam penyelesaian masalah kesehatan, pendamping dalam pelaksanaan pemantauan dan evaluasi; serta pendamping masyarakat dan/atau melakukan pendekatan kepada pemangku kepentingan terkait. Tenaga pendamping dapat berasal dari organisasi kemasyarakatan, swasta, perguruan tinggi, dan/atau anggota masyarakat. Kriteria dan tugas tersebut lebih sesuai dengan karakteristik teman-teman komunitas yang bekerja sebagai tenaga lapangan dan pendamping dalam program pengendalian HIV nasional dan daerah. Hanya saja penggunaan wilayah desa/kelurahan dalam Pemenkes ini masih terasa kurang relevan.

Berdasarkan analisis dokumen kebijakan tentang pengendalian HIV pada di bawah ini dapatlah disampaikan bahwa secara fundamental, perundangan yang mendukung keterlibatan dan peran komunitas dalam upaya pengendalian HIV sejak dari cascade promotif-preventif hingga kuratifrehabilitatif sudah ada dan cukup kondusif memberikan ruang dan peluang bagi komunitas pemerhati HIV untuk berkarya. Akan tetapi, integrasi secara resmi, sinergisitas dan harmonisasinya dengan fasilitas layanan kesehatan HIV belum tercantumkan secara resmi. Inklusi peran komunitas secara resmi dan terukur menggunakan SIHA yang sudah ada dalam tata laksana layanan HIV di fasilitas layanan kesehatan, termasuk juga PDP perlu diupayakan pemerintah supaya kinerja komunitas ini tidak hanya dapat direalisasikan dan diapresiasi, namun juga dapat terevaluasi secara terstruktur seperti halnya evaluasi terhadap capaian berkala program HIV lainnya. 


\begin{tabular}{|c|c|c|}
\hline Dokumen & Pokok kebijakan yang terkait dengan pemosisian komunitas & Pemosisian komunitas \\
\hline $\begin{array}{l}\text { UU Nomor } 6 / 2009 \\
\text { tentang kesehatan }\end{array}$ & $\begin{array}{l}\text { - Upaya kesehatan juga dilakukan oleh dan bersama masyarakat, sejak dari } \\
\text { pencegahan penyakit, peningkatan kesehatan, pengobatan penyakit, dan pemulihan } \\
\text { kesehatan. } \\
\text { - Tanggung jawab pemerintah untuk memberdayakan dan mendorong peran aktif } \\
\text { masyarakat dalam segala bentuk upaya kesehatan. Pemerintah berkewajiban } \\
\text { memberikan pembinaan dan pengawasan terhadap masyarakat dalam segala upaya } \\
\text { kesehatan. Masyarakat juga berperan dalam fungsi pengawasan upaya kesehatan. } \\
\text { - Pemerintah menjamin dan menyediakan fasilitas untuk kelangsungan upaya } \\
\text { peningkatan kesehatan dan pencegahan penyakit, termasuk ketersediaan sarana } \\
\text { informasi yang benar dan dapat dipertanggungjawabkan. } \\
\text { - Pemerintah menjamin pembiayaan sektor kesehatan dengan prinsip kesinambungan, } \\
\text { mencukupi, alokasi yang adil, termanfaatkan, berhasil guna, dan berdaya guna. } \\
\text { Sumber pembiayaan: pemerintah, pemda, masyarakat, swasta, dan sumber lain. } \\
\text { - Peran serta masyarakat diakui dalam perundangan ini, baik secara perorangan } \\
\text { maupun terorganisasi, berupa peran aktif dan kreatif. }\end{array}$ & $\begin{array}{l}\text { Pemberdayaan masyarakat, } \\
\text { dalam hal ini peran masyarakat } \\
\text { lebih sebagai anjuran, karenanya } \\
\text { masyarakatlah yang diharapkan } \\
\text { berinisiatif dan aktif } \\
\text { berpartisipasi. Partisipasi tidak } \\
\text { bersifat wajib. } \\
\text { Tidak ada sanksi dan tidak ada } \\
\text { penghargaan secara khusus } \\
\text { terkait komunitas sebagai bagian } \\
\text { dari masyarakat ketika } \\
\text { berpartisipasi dalam upaya } \\
\text { kesehatan nasional maupun } \\
\text { daerah. }\end{array}$ \\
\hline $\begin{array}{l}\text { PP Nomor } 72 / 2012 \\
\text { tentang SKN }\end{array}$ & $\begin{array}{l}\text { - Pelaksanaan SKN ditekankan pada peningkatan perilaku dan kemandirian } \\
\text { masyarakat, profesionalisme sumber daya manusia kesehatan, serta upaya promotif } \\
\text { dan preventif tanpa mengesampingkan upaya kuratif dan rehabilitatif. } \\
\text { - Penerapan SKN harus memperhatikan cakupan pelayanan kesehatan berkualitas, } \\
\text { adil, dan merata; inovasi atau terobosan ilmu pengetahuan dan teknologi yang etis } \\
\text { dan terbukti bermanfaat dalam penyelenggaraan pembangunan kesehatan secara } \\
\text { luas, termasuk penguatan sistem rujukan; epidemiologi penyakit dan globalisasi, } \\
\text { demokratisasi dan desentralisasi dengan semangat persatuan dan kesatuan nasional } \\
\text { serta kemitraan dan kerja sama lintas sektor. } \\
\text { - Prinsip dasar pembangunan kesehatan terdiri dari perikemanusiaan, pemberdayaan } \\
\text { dan kemandirian, adil dan merata, serta pengutamaan dan manfaat. }\end{array}$ & $\begin{array}{l}\text { Pemberdayaan dan peningkatan } \\
\text { kemandirian masyarakat dalam } \\
\text { segala upaya kesehatan. }\end{array}$ \\
\hline
\end{tabular}

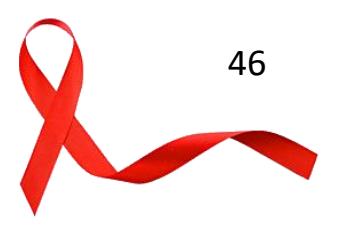




\begin{tabular}{|c|c|c|}
\hline $\begin{array}{l}\text { PMK Nomor 43/2016 } \\
\text { tentang SPM Bidang } \\
\text { Kesehatan }\end{array}$ & $\begin{array}{l}\text { - Langkah-langkah kegiatan pelayanan HIV dilakukan dengan pemetaan kelompok } \\
\text { sasaran; Penyiapan SDM; Promosi/penyuluhan; Jejaring kerja dan kemitraan; } \\
\text { Sosialisasi; Pemeriksaan HIV; Rujukan kasus HIV untuk mendapatkan pengobatan } \\
\text { ART; Pencatatan dan pelaporan; Monitoring dan evaluasi, setiap langkah ini } \\
\text { diperhitungkan pembiayaannya. Unit cost mengacu pada Perda dan atau standar } \\
\text { biaya yang berlaku di daerah setempat. } \\
\text { - Sumber Daya Manusia yang diperlukan dalam Kegiatan Pelayanan HIV adalah Dokter } \\
\text { Spesialis sesuai kewenangannya, Dokter/Dokter gigi di FKTP, FKTL dan lapas/rutan } \\
\text { yang terlatih HIV;Tenaga kesehatan di FKTP, FKTL dan lapas/rutan yang terlatih HIV } \\
\text { atau Konselor HIV; Pranata Laboratorium Kesehatan di Puskesmas dan RS yang } \\
\text { terlatih Pemeriksaan HIV; Petugas pencatatan dan pelaporan/Perekam Medis yang } \\
\text { terlatih di bidang pencatatan dan pelaporan HIV AIDS dan PIMS;Pengelola Program } \\
\text { HIV dan IMS di Kabupaten/Kota. } \\
\text { - Monitoring dan Evaluasi Pelayanan HIV dilakukan dengan menggunakan Register } \\
\text { SIHA di fasilitas layanan kesehatan, Laporan triwulan SIHA di Dinkes Kabupaten/Kota, } \\
\text { dan Estimasi sasaran kelompok berisiko. }\end{array}$ & $\begin{array}{l}\text { Sebagai jejaring dan Mitra dalam } \\
\text { pemeriksaan HIV/ Rujukan kasus. } \\
\text { Sebagai anggota komunitas ada } \\
\text { peluang untuk aktif dalam } \\
\text { fasilitas kesehatan sebagai } \\
\text { konselor perorangan, dan tidak } \\
\text { mewakili komunitas tertentu. }\end{array}$ \\
\hline $\begin{array}{l}\text { PMK Nomor 45/2014 } \\
\text { tentang } \\
\text { Penyelenggaraan } \\
\text { Surveilans Kesehatan }\end{array}$ & $\begin{array}{l}\text { - Salah satu jenis surveilans kesehatan adalah surveilans HIV.Penyelenggaraan } \\
\text { Surveilans Kesehatan harus didukung dengan tersedianya sumber daya manusia yang } \\
\text { memiliki kompetensi di bidang epidemiologi; pendanaan yang memadai; dan sarana } \\
\text { dan prasarana yang diperlukan termasuk pemanfaatan teknologi tepat guna. } \\
\text { - Dalam rangka penyelenggaraan surveilans kesehatan, dibangun dan dikembangkan } \\
\text { koordinasi, jejaring kerja, dan kemitraan antar instansi pemerintah dan pemangku } \\
\text { kepentingan baik di pusat, provinsi, maupun kabupaten/kota. }\end{array}$ & $\begin{array}{l}\text { Jejaring kerja dan kemitraan yang } \\
\text { berpotensi memayungi kinerja } \\
\text { pengendalian HIV yang bisa } \\
\text { melibatkan komunitas. }\end{array}$ \\
\hline $\begin{array}{l}\text { PMK Nomor 21/2013 } \\
\text { tentang Pengendalian } \\
\text { HIV dan AIDS }\end{array}$ & $\begin{array}{l}\text { - Prinsip pengendalian HIV terintegrasi dengan program pembangunan di tingkat } \\
\text { nasional, provinsi dan kabupaten/ kota; dilakukan secara sistematis dan terpadu; } \\
\text { dilakukan oleh masyarakat dan pemerintah berdasarkan kemitraan; dan melibatkan } \\
\text { peran aktif populasi kunci dan ODHIV serta orang-orang yang terdampak HIV dan } \\
\text { AIDS. } \\
\text { - Strategi yang dipergunakan dalam melakukan kegiatan Pengendalian HIV meliputi } \\
\text { peningkatan pemberdayaan masyarakat dalam pengendalian HIV melalui kerjasama } \\
\text { nasional, regional, dan global dalam aspek legal,organisasi, pembiayaan, fasilitas } \\
\text { pelayanan kesehatan dan sumber daya manusia; meningkatkan upaya pengendalian }\end{array}$ & $\begin{array}{l}\text { Pemberdayaan masyarakat dan } \\
\text { kemitraan dari pemerintah. } \\
\text { Pernyataan komitmen untuk } \\
\text { membina kelompok-kelompok } \\
\text { dukungan. } \\
\text { Pendanaan kegiatan } \\
\text { pengendalian HIV bekerjasama } \\
\text { dengan pemerintah ataupun } \\
\text { mitra international. }\end{array}$ \\
\hline
\end{tabular}




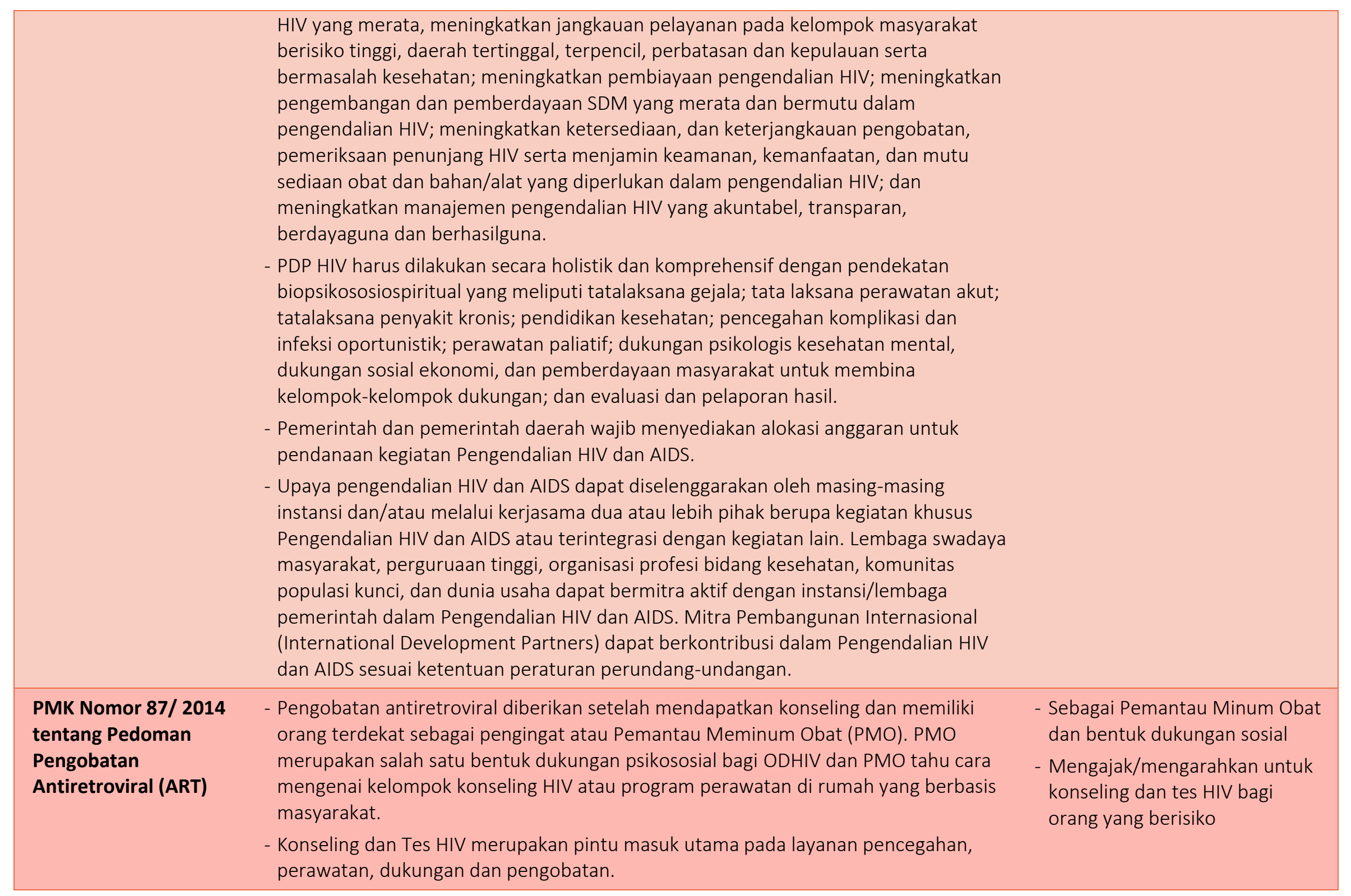




\begin{tabular}{|c|c|c|}
\hline $\begin{array}{l}\text { PMK Nomor } 74 / 2014 \\
\text { tentang Pedoman } \\
\text { Pelaksanaan Konseling } \\
\text { dan Tes }\end{array}$ & $\begin{array}{l}\text { Layanan konseling dan tes HIV (KTHIV) atau VCT di fasilitas pelayanan kesehatan dapat } \\
\text { diselenggarakan di berbagai tatanan di komunitas, baik dengan cara menjangkau klien } \\
\text { potensial dan mendorong mereka datang (layanan statis), atau pun dengan } \\
\text { menyelenggarakan layanan ke tempat mereka berada (layanan bergerak/mobile). }\end{array}$ & $\begin{array}{l}\text { Menjangkau klien layanan HIV } \\
\text { potensial dan } \\
\text { mengajak/mengarahkan untuk } \\
\text { mengakses layanan }\end{array}$ \\
\hline $\begin{array}{l}\text { PMKNomor 15/ } 2015 \\
\text { tentang Pelayanan } \\
\text { Laboratorium } \\
\text { Pemeriksa HIV dan } \\
\text { Infeksi Oportunistik }\end{array}$ & $\begin{array}{l}\text { - Penyelenggaraan Pelayanan Laboratorium Pemeriksa HIV dan Infeksi Oportunistik } \\
\text { harus didukung oleh ketersediaan sumber daya laboratorium dan standar prosedur } \\
\text { operasional yang memadai. Sumber daya laboratorium meliputi sumber daya } \\
\text { manusia dan sarana dan prasarana. } \\
\text { - Untuk meningkatkan jangkauan dan efisiensi Pelayanan Laboratorium Pemeriksa HIV } \\
\text { dan Infeksi Oportunistik harus dibentuk jejaring. Jejaring/integrasi dilakukan pada } \\
\text { fasilitas kesehatan primer hingga tersier bahkan laboratorium nasional. } \\
\text { - Dalam melakukan pelayanan, setiap laboratorium pemeriksa HIV dan infeksi } \\
\text { oportunistik harus menggunakan reagen diagnostik HIV yang memiliki izin edar. }\end{array}$ & $\begin{array}{l}\text { Jejaring dari layanan kesehatan. } \\
\text { Komunitas dan perwakilannya } \\
\text { berpotensi untuk bisa dilibatkan } \\
\text { dalam upaya pemeriksaan HIV } \\
\text { secara mandiri menggunakan self- } \\
\text { test kit sehingga dapat } \\
\text { meningkatkan angka tes HIV di } \\
\text { antara potensial klien dan } \\
\text { anggota populasi risti. }\end{array}$ \\
\hline $\begin{array}{l}\text { PP Nomor } 46 / 2014 \\
\text { tentang Sistem } \\
\text { Informasi Kesehatan }\end{array}$ & $\begin{array}{l}\text { Pengaturan Sistem Informasi Kesehatan ini bertujuan untuk menjamin ketersediaan, } \\
\text { kualitas, dan akses terhadap Informasi Kesehatan yang bernilai pengetahuan serta } \\
\text { dapat dipertanggungjawabkan; memberdayakan peran serta masyarakat, termasuk } \\
\text { organisasi profesi dalam penyelenggaraan Sistem Informasi Kesehatan; dan } \\
\text { mewujudkan penyelenggaraan Sistem Informasi Kesehatan dalam ruang lingkup sistem } \\
\text { kesehatan nasional yang berdaya guna dan berhasil guna terutama melalui penguatan } \\
\text { kerja sama, koordinasi, integrasi, dan sinkronisasi dalam mendukung penyelenggaraan } \\
\text { pembangunan kesehatan yang berkesinambungan. }\end{array}$ & $\begin{array}{l}\text { Mendukung sistem informasi } \\
\text { kesehatan dalam bentuk } \\
\text { koordinasi dengan fasilitas } \\
\text { kesehatan. Dalam hal ini, jika } \\
\text { peran komunitas telah } \\
\text { terintegrasikan secara resmi } \\
\text { dalam jaringan layanan HIV } \\
\text { nasional, pelaporan kinerja } \\
\text { komunitas pun dapat } \\
\text { diinformasikan melalui SIHA. }\end{array}$ \\
\hline $\begin{array}{l}\text { Permendagri Nomor } \\
20 / 2007 \text { tentang } \\
\text { pedoman umum } \\
\text { pembentukan KPA dan } \\
\text { pemberdayaan } \\
\text { masyarakat dalam } \\
\text { rangka pengendalian } \\
\text { HIV dan AIDS di daerah }\end{array}$ & $\begin{array}{l}\text { - Pengendalian HIV dan AIDS dilaksanakan secara terpadu dengan Program } \\
\text { Pemberdayaan Masyarakat yang ada dengan prinsip transparansi, partisipatif, dan } \\
\text { akuntabilitas, serta memperhatikan nilai agama dan budaya/norma masyarakat yang } \\
\text { ada di Indonesia. } \\
\text { - Program Pemberdayaan Masyarakat adalah memberdayakan masyarakat agar } \\
\text { masyarakat tahu, mau, dan mampu menanggulangi HIV. Pemberdayaan Masyarakat } \\
\text { melibatkan masyarakat, lembaga kemasyarakatan, Badan Permusyawaratan Desa, } \\
\text { Kader Pemberdayaan Masyarakat, tokoh agama, tokoh masyarakat, LSM, swasta, } \\
\text { ODHIV, dan sebagainya dan menitikberatkan pada semua aspek pengendalian HIV }\end{array}$ & $\begin{array}{l}\text { Melibatkan pemberdayaan } \\
\text { masyarakat terkait pengendalian } \\
\text { HIV. } \\
\text { Namun, sudah tidak relevan lagi } \\
\text { sejak purna tugas KPAN dan KPAD } \\
\text { dengan Perpres Nomor } 124 / 2016 \text {. }\end{array}$ \\
\hline
\end{tabular}




\begin{tabular}{|c|c|c|}
\hline & $\begin{array}{l}\text { sesuai dengan peran masing-masing, termasuk pencegahan diskriminasi dan } \\
\text { stigmatisasi terhadap ODHIV dan keluarganya. }\end{array}$ & \\
\hline $\begin{array}{l}\text { PMK Nomor } 52 / 2017 \\
\text { Tentang Eliminasi } \\
\text { Penularan Human } \\
\text { Immunodeficiency } \\
\text { Virus, Sifilis, Dan } \\
\text { Hepatitis B Dari Ibu Ke } \\
\text { Anak }\end{array}$ & $\begin{array}{l}\text { Strategi program eliminasi penularan meliputi: peningkatan akses dan kualitas layanan } \\
\text { kesehatan bagi ibu dan anak sesuai dengan standar; peningkatan peran fasilitas } \\
\text { pelayanan kesehatan dalam penatalaksanaan yang diperlukan untuk eliminasi } \\
\text { penularan; peningkatan penyediaan sumber daya di bidang kesehatan; peningkatan } \\
\text { jejaring kerja dan kemitraan serta kerja sama lintas program dan lintas sektor; dan } \\
\text { peningkatan peran serta masyarakat. }\end{array}$ & $\begin{array}{l}\text { Jejaring dan mitra kerja layanan } \\
\text { kesehatan. Komunitas berpotensi } \\
\text { menjadi partner yang dapat } \\
\text { memberikan dampingan dan } \\
\text { informasi tentang kesehatan ibu } \\
\text { dan anak selama kehamilan, serta } \\
\text { dukungan untuk mengakses } \\
\text { layanan kesehatan yang tepat } \\
\text { dengan prosedur yang tepat }\end{array}$ \\
\hline $\begin{array}{l}\text { SE Menkes No: } \\
\text { HK.02.02/1/1564/2018 } \\
\text { tentang Penatalaksaan } \\
\text { ODHIV untuk Eliminasi } \\
\text { HIV AIDS Tahun } 2030\end{array}$ & $\begin{array}{l}\text { - Layanan tes HIV memperbaharui istilah konseling dan tes HIV, dan mencakup tes HIV } \\
\text { lengkap yaitu tes atas inisiasi petugas, jejaring dengan layanan perawatan, hasil tes } \\
\text { yang benar, konseling, jaminan kualitas dan lain-lain. } \\
\text { - Pemeriksaan/Tes HIV juga "dimintakan secara rutin" (menggantikan "ditawarkan") } \\
\text { untuk pasien fasilitas layanan kesehatan di daerah epidemi meluas (misal Papua dan } \\
\text { Papua barat dan di daerah lain dilakukan pada pasien dengan gejala HIV AIDS } \\
\text { termasuk anak malnutrisi, semua pasien TB, ibu hamil, semua pasien IMS, semua } \\
\text { pasien Hepatitis B dan C, populasi kunci, warga binaan, dan pasangan ODHIV. } \\
\text { - Pengobatan ART juga diatur dalam surat edaran ini bahwa pengobatan ART diberikan } \\
\text { dengan memberikan edukasi mengenai manfaat dari ART ini dan ART dapat diberikan } \\
\text { saat diagnosis HIV ditegakkan jika ODHIV siap dan tidak ada kontraindikasi klinis. }\end{array}$ & $\begin{array}{l}\text { - Membantu merujukkan klien } \\
\text { potensia untuk akses layanan } \\
\text { tes HIV } \\
\text { - Memberikan edukasi atau } \\
\text { mengadakan diskusi berkala } \\
\text { tentang HIV ke komunitas } \\
\text { populasi kunci dan risti } \\
\text { - Memberikan edukasi manfaat } \\
\text { ART bagi ODHIV }\end{array}$ \\
\hline $\begin{array}{l}\text { Keputusan Menteri } \\
\text { Kesehatan Nomor HK. } \\
\text { 1278/Menkes } \\
\text { /SK/XII/2009 tentang } \\
\text { Pedoman Pelaksanaan } \\
\text { Kolaborasi } \\
\text { Pengendalian Penyakit } \\
\text { TB dan HIV }\end{array}$ & $\begin{array}{l}\text { - Pelaksanaan kolaborasi TB-HIV dilakukan dengan mengatur mekanisme kolaborasi } \\
\text { yaitu membentuk POKJA dan surveilance TB-HIV hingga mengadakan promosi } \\
\text { komunikasi perubahan perilaku dan membangun dukungan masyarakat bagi } \\
\text { kolaborasi TB-HIV. Kolaborasi juga mengikutsertakan perencanaan bersama TB-HIV } \\
\text { yaitu dengan memetakan sumber daya TB-HIV, membangun kapasitas TB-HIV/ } \\
\text { pelatihan, komunikasi - Advokasi TB-HIV, meningkatkan keterlibatan masyarakat } \\
\text { dalam kolaborasi TB -HIV. } \\
\text { - Tujuan lainnya dari peraturan ini adalah menurunkan beban HIV pada pasien TB yaitu } \\
\text { dengan memberikan akses PDP HIV yang komprehensif yang meliputi manajemen }\end{array}$ & $\begin{array}{l}\text { - Menjadi bagian dalam } \\
\text { kolaborasi pengendalian TB HIV } \\
\text { - Dapat berpartisipasi aktif dalam } \\
\text { perawatan berbasis rumah } \\
\text { termasuk juga contact tracing } \\
\text { TB }\end{array}$ \\
\hline
\end{tabular}




\begin{tabular}{|c|c|c|}
\hline & $\begin{array}{l}\text { klinis, asuhan perawatan, perawatan paliatif, perawatan berbasis rumah, dukungan } \\
\text { konseling dan sosial, dan sistem rujukan pasien. }\end{array}$ & \\
\hline $\begin{array}{l}\text { PMK No.61 Tahun } 2017 \\
\text { tentang Petunjuk } \\
\text { Teknis Dana Alokasi } \\
\text { Khusus Bidang } \\
\text { Kesehatan }\end{array}$ & $\begin{array}{l}\text { - Pengelolaan DAK Nonfisik Bidang Kesehatan salah satunya adalah Dana Bantuan } \\
\text { Operasional Kesehatan (BOK) Puskesmas yang dapat digunakan untuk Upaya } \\
\text { Pencegahan dan pengendalian Penyakit Menular Langsung seperti HIV. } \\
\text { - BOK diarahkan untuk mendekatkan petugas kesehatan kepada masyarakat dan } \\
\text { memberdayakan masyarakat melalui mobilisasi kader kesehatan untuk berperan } \\
\text { aktif dalam pembangunan kesehatan yang dilakukan melalui pendekatan keluarga }\end{array}$ & $\begin{array}{l}\text { Pemberdayaan komunitas sebagai } \\
\text { Penjangkau Lapangan/Kader yang } \\
\text { pendanaannya bisa bersumber } \\
\text { dari DAK tersebut yang disertai } \\
\text { dengan kinerja terukur. }\end{array}$ \\
\hline $\begin{array}{l}\text { SE Menkes No: } \\
\text { PM.02.02/3/2022/2020 } \\
\text { tentang Protokol } \\
\text { Pelayanan HIV AIDS } \\
\text { selama Pandemi } \\
\text { COVID-19 }\end{array}$ & $\begin{array}{l}\text { Peraturan ini menghimbau untuk mampu menerapkan kewaspadaan standar untuk } \\
\text { pencegahan dan pengendalian infeksi ketika melakukan layanan perawatan, dukungan, } \\
\text { dan pengobatan HIV AIDS; mendahulukan ODHIV dengan gejala batuk, flu, atau } \\
\text { lainnya;mempertimbangkan penyediaan ART selama } 2-3 \text { bulan bagi ODHIV stabil } \\
\text { dengan melihat stok ketersediaan ART; Bagi ODHIV dengan IO (Infeksi oportunistik) atau } \\
\text { ART pertama disarankan kontrol setiap bulannya; perlu adanya kerjasama } \\
\text { komunitas/pendukung ODHIV untuk memastikan kondisi dan keberlangsungan } \\
\text { pengobatan ART pada ODHIV; penyediaan informasi melalui media untuk tetap } \\
\text { menerapkan perilaku hidup bersih dan sehat selama COVID-19;Dinkes memantau dan } \\
\text { memastikan keberlangsungan layanan ART pada ODHIV agar patuh minum ART dan lost } \\
\text { to follow up tidak meningkat; dan memastikan agar alat pencegahan HIV AIDS tersedia } \\
\text { di layanan kesehatan. }\end{array}$ & $\begin{array}{l}\text { Memastikan kondisi dan } \\
\text { keberlangsungan pengobatan ART } \\
\text { pada ODHIV melaui koordinasi } \\
\text { dan mediasi antara fasilitas } \\
\text { layanan kesehatan dengan } \\
\text { ODHIV. }\end{array}$ \\
\hline $\begin{array}{l}\text { PMK Nomor } 8 \text { Tahun } \\
2019 \text { tentang } \\
\text { Pemberdayaan } \\
\text { Masyarakat Bidang } \\
\text { Kesehatan }\end{array}$ & $\begin{array}{l}\text { - Pengaturan pemberdayaan masyarakat digunakan sebagai acuan bagi pemerintah } \\
\text { pusat, pemerintah daerah, lembaga kemasyarakatan, organisasi kemasyarakatan, } \\
\text { swasta, dan pemangku kepentingan terkait lainnya dalam mewujudkan peran aktif } \\
\text { dan kemandirian masyarakat untuk hidup sehat. } \\
\text { - Strategi Pemberdayaan Masyarakat meliputi: peningkatan pengetahuan dan } \\
\text { kemampuan masyarakat dalam mengenali dan mengatasi permasalahan kesehatan } \\
\text { yang dihadapi; peningkatan kesadaran masyarakat melalui penggerakan masyarakat; } \\
\text { pengembangan dan pengorganisasian masyarakat; peningkatan kemitraan dan } \\
\text { partisipasi lintas sektor, lembaga kemasyarakatan, organisasi kemasyarakatan, dan } \\
\text { swasta; peningkatan pemanfaatan potensi dan sumber daya berbasis kearifan lokal; } \\
\text { dan pengintegrasian program, kegiatan, dan/atau kelembagaan pemberdayaan } \\
\text { masyarakat yang sudah ada sesuai dengan kebutuhan dan kesepakatan masyarakat. }\end{array}$ & $\begin{array}{l}\text { Berpartisipasi aktif menjadi kader } \\
\text { maupun tenaga pendamping } \\
\text { khususnya dalam pengendalian } \\
\text { penyakit menular (HIV) }\end{array}$ \\
\hline
\end{tabular}




- Pengendalian penyakit menular dan tidak menular masuk dalam kegiatan
pemberdayaan masyarakat yang dilaksanakan dengan mengutamakan pendekatan
promotif dan preventif.
- Masyarakat menyelenggarakan Pemberdayaan Masyarakat dengan didampingi oleh
Tenaga Pendamping. Tenaga Pendamping adalah seseorang yang berasal dari
Pemerintah Pusat, Pemerintah Daerah, lembaga kemasyarakatan, organisasi
kemasyarakatan, swasta, perguruan tinggi, dan/atau anggota masyarakat yang
memiliki kemampuan sebagai Tenaga Pendamping yang didapat melalui pelatihan
oleh Pemerintah.
- Pemberdayaan Masyarakat juga memerlukan keterlibatan Kader. Kader berperan
sebagai: penggerak masyarakat untuk berperan serta dalam upaya kesehatan sesuai
kewenangannya; penggerak masyarakat agar memanfaatkan UKBM dan pelayanan
kesehatan dasar; pengelola UKBM bersama puskesmas dan ditetapkan sesuai
dengan peraturan desa/ peraturan yang berlaku; penyuluh kesehatan kepada
masyarakat; pencatat kegiatan pemberdayaan masyarakat bidang kesehatan; dan
pelapor jika ada permasalahan atau kasus kesehatan setempat pada tenaga
kesehatan.

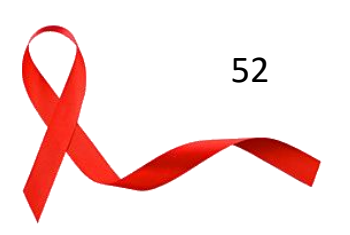


Hasil identifikasi positioning komunitas menunjukkan sudah banyak kebijakan dan regulasi mengenai dukungan pengendalian HIV di Indonesia namun terdapat kesenjangan yaitu situasi epidemi HIV di Indonesia yang merupakan epidemi terkonsentrasi pada populasi kunci dengan aktor yang terlibat dalam kebijakan pelayanan kesehatan terkait HIV. Aktor atau organisasi yang terlibat masih lebih banyak didominasi sektor publik dan belum terintegrasi dengan banyak melibatkan komunitas.

Peran organisasi dan aktor komunitas yang dominan dalam penyelenggaraan pelayanan promotif dan preventif pada populasi kunci yaitu dalam hal rujukan tes dan pengobatan. Hal ini mengakibatkan seolah-olah di tatanan pelaksanaan telah terbentuk sistem pelayanan yang terpisah dari sistem pelayanan kesehatan umumnya. Studi terkini tentang integrasi program HIV di Indonesia menyimpulkan bahwa integrasi kegiatan yang dilakukan oleh organisasi dan aktor komunitas ke dalam sistem pelayanan kesehatan masih lemah. ${ }^{21}$ Penyebab utama dari masalah integrasi ini adalah dominannya anggaran kegiatan yang berasal dari donor ditambah dengan penggunaan sistem informasi dan pengambilan keputusan yang berbeda dengan sistem informasi kesehatan nasional. Upaya untuk mendorong integrasi yang lebih luas ke sistem pelayanan kesehatan harus segera dilakukan. Pemerintah pusat juga perlu merangkul pemerintah daerah agar dengan adanya desentralisasi pemerintah daerah memiliki kesamaan persepsi tentang tujuan program HIV sehingga bisa memastikan kebijakan dan panduan yang dikeluarkan oleh pemerintah pusat dilaksanakan dengan patuh di setiap daerah. Keterpaduan komponen khususnya di daerah juga mendorong Puskesmas sebagai layanan lini pertama untuk bisa memberikan pengobatan ART usaha yang lebih aktif dengan cara menjemput pasien dan memastikan akses mereka terhadap PDP HIV yang dapat melibatkan komunitas dalam membantu upaya tersebut. 


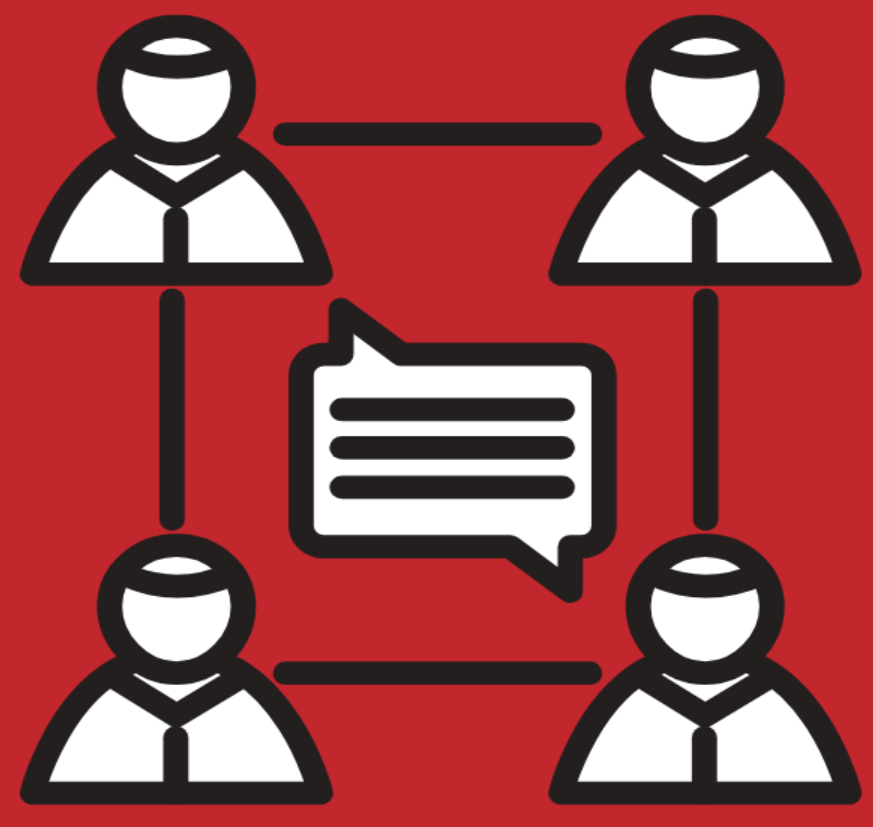

\section{Survei Delphi Positioning Layanan Komunitas dalam SKN (Siklus 1)}

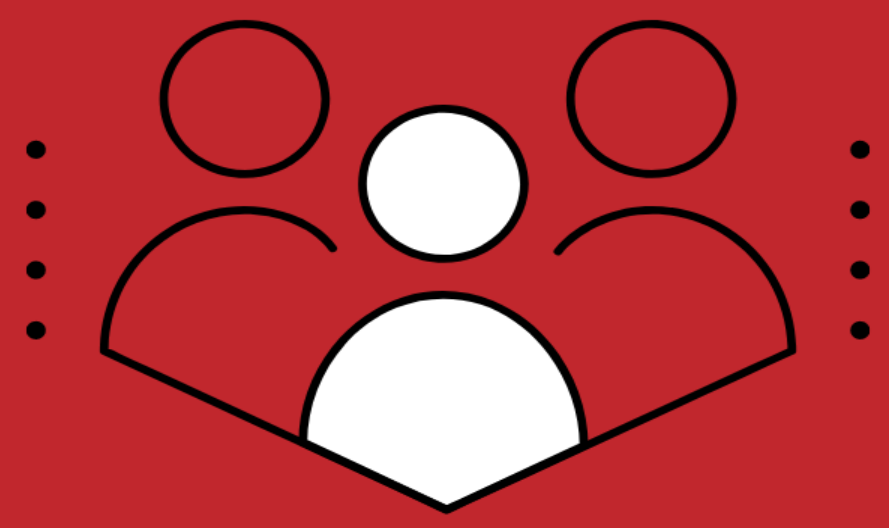




\section{Survei Delphi Positioning Layanan Komunitas dalam SKN (Siklus 1)}

\subsection{Deskripsi dan Tujuan}

Berdasarkan analisis dokumen kebijakan dan kajian literatur sistematis yang telah dilakukan, disusun model positioning layanan komunitas dalam masing-masing fungsi layanan. Dalam metode Delphi ini dikaji tingkat persetujuan para pakar terkait penerapan model ini di Indonesia. Adapun tujuan spesifik dari survei Delphi adalah:

1. Sintesis tingkat continuum of integration yang ideal untuk positioning layanan komunitas dalam SKN.

2. Identifikasi kelemahan model layanan komunitas dalam SKN dan bagian yang dapat diperbaiki.

3. Mengukur persepsi pakar kesehatan masyarakat mengenai model layanan komunitas dalam SKN.

\subsection{Metode Delphi}

Metode Delphi dilakukan untuk menampung pendapat para pakar. Para pakar yang berpartisipasi dalam model Delphi akan diminta untuk menilai dua aspek mengenai model layanan komunitas dalam SKN terkait layanan HIV. Aspek pertama adalah keandalan (reliability), yaitu terkait ketepatan model layanan komunitas yang sudah disusun dibandingkan dengan positioning layanan komunitas dalam opini para pakar yang berpartisipasi. Aspek yang kedua adalah kelayakan (feasibility), yang meliputi opini para pakar mengenai kemungkinan penerapan model penempatan yang sudah disusun dalam kondisi di lapangan.

Partisipan. Panelis pakar yang diundang untuk berpartisipasi terdiri atas 78 orang pakar dari berbagai latar belakang. Organisasi yang terwakili dalam daftar pakar yang diundang berpartisipasi meliputi organisasi pemerintahan, lembaga pembangunan internasional, lembaga swadaya masyarakat yang bergerak di bidang HIV, organisasi komunitas, penyedia layanan kesehatan komunitas, serta akademisi dari lembaga riset dan universitas. Para pakar yang dimintai pendapat dihubungi melalui email dan diberi waktu selama 1 (satu) minggu untuk memberi tanggapan.

Pengumpulan data. Pengumpulan data dilakukan sekurang-kurangnya sebanyak 2 siklus dan maksimal sebanyak 3 putaran dalam setiap siklusnya. Siklus pertama bertujuan utama untuk menampung opini para pakar yang berpartisipasi mengenai masing-masing kegiatan partisipasi komunitas dalam fungsi layanan kesehatan HIV. Model layanan komunitas akan direvisi dan disusun ulang berdasarkan masukan para pakar yang diperoleh dari siklus pertama. Siklus kedua dan ketiga dilakukan untuk menjaring pendapat pakar lebih lanjut. Konsensus diharapkan tercapai pada akhir siklus ketiga. 


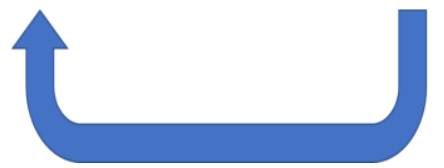

Gambar 4. Ilustrasi Alur Metode Delphi.

Dalam siklus pertama pengumpulan data ini, partisipan akan diminta pendapat untuk masingmasing kegiatan keterlibatan komunitas (Lampiran 4). Pendapat disampaikan dalam bentuk skala Likert dengan 5 item mulai dari 'sangat tidak setuju' hingga 'sangat setuju'. Para pakar yang berpartisipasi juga diberi kesempatan untuk memberi masukan mengenai model penempatan yang telah disusun, baik berupa kritik maupun saran, melalui uraian singkat.

Model integrasi yang diujikan pada pakar terkait. Berdasarkan tinjauan pustaka yang telah dilakukan, telah teridentifikasi beberapa peran komunitas dalam berbagai fungsi layanan kesehatan terkait HIV. Peran komunitas teridentifikasi mulai dari kegiatan proses pencegahan dan perubahan perilaku, diagnosis dini, manajemen medis dan retensi, hingga memfasilitasi komunikasi antara pasien, organisasi komunitas, dan layanan kesehatan, seperti dapat dilihat dalam tabel berikut:

\section{Tabel 4. Peran Komunitas dalam Fungsi Layanan HIV/AIDS}

\begin{tabular}{|ll|}
\hline No & \multicolumn{1}{c|}{ Fungsi Layanan HIV/AIDS } \\
\hline $\mathbf{1}$ & Pencegahan; layanan perubahan perilaku \\
\hline $\mathbf{2}$ & Diagnosis tepat dan cepat termasuk skrining berbasis komunitas dan metode lainnya \\
\hline $\mathbf{3}$ & $\begin{array}{l}\text { Manajemen medis dan klinis termasuk layanan dukungan diagnostik dan dukungan memulai } \\
\text { terapi }\end{array}$ \\
\hline $\mathbf{4}$ & Dukungan pengobatan; retensi, manajemen mandiri, dan dukungan peer \\
\hline $\mathbf{5}$ & Dukungan psikososial dalam konteks lokal/kultural/religius \\
\hline $\mathbf{6}$ & $\begin{array}{l}\text { Komunikasi dan koordinasi antar organisasi penyedia layanan, pasien dan komunitas/organisasi } \\
\text { komunitas }\end{array}$ \\
\hline $\mathbf{7}$ & Pelibatan aktif masyarakat dalam penelitian HIV \\
\hline
\end{tabular}

Konsep continuum of integration merupakan sesuatu yang penting dalam kerangka pikir positioning layanan komunitas dalam SKN. Dalam konsep ini, integrasi antara dua sistem (dalam hal ini adalah sistem layanan kesehatan dan komunitas), terjadi pada tingkatan-tingkatan dalam sebuah continuum mulai dari koordinasi, kolaborasi, dan integrasi. Selain itu, dalam hal pelayanan HIV, tingkatan-tingkatan ini dapat dijabarkan baik untuk pelayanan kesehatan langsung pada populasi kunci dan ODHIV serta pelaksanaan program-program mitigasi HIV, sebagaimana dapat dilihat dalam tabel berikut.

Tabel 5. Tingkat Continuum of Integration untuk Layanan HIV. 


\begin{tabular}{|c|c|c|}
\hline & Layanan Kesehatan & Pelaksanaan Program \\
\hline Koordinasi & Saluran komunikasi untuk rujukan & $\begin{array}{l}\text { Saluran komunikasi dalam } \\
\text { pelaksanaan program } \\
\text { Saling penyediatahuan mengenai } \\
\text { pelaksanaan kegiatan masing- } \\
\text { masing }\end{array}$ \\
\hline Kolaborasi & $\begin{array}{l}\text { Penyediaan layanan satu lokasi } \\
\text { Database bersama untuk riwayat } \\
\text { pasien } \\
\text { > Penyusunan standar pelayanan } \\
\text { bersama }\end{array}$ & $\begin{array}{l}\text { Perencanaan dan evaluasi program } \\
\text { bersama } \\
\text { Penyusunan standar operasi } \\
\text { bersama }\end{array}$ \\
\hline Integrasi & $\begin{array}{l}\text { Pengambilan keputusan bersama } \\
\text { untuk pelayanan kesehatan pasien }\end{array}$ & $\begin{array}{l}\text { Pelaksanaan program secara } \\
\text { interdependen } \\
\text { Perencanaan, pelaksanaan, dan } \\
\text { evaluasi program harus dikerjakan } \\
\text { oleh semua komponen }\end{array}$ \\
\hline
\end{tabular}

Dalam hal pelayanan kesehatan, continuum of integration dimulai dari tingkatan terendah tanpa adanya integrasi di mana layanan kesehatan dan layanan komunitas tidak berbagi informasi tentang kondisi pasien atau klien dan memberikan layanan secara terpisah dan saling terisolasi. Dalam tingkatan berikutnya, koordinasi, maka terbuka saluran komunikasi untuk saling merujuk pasien atau klien antara layanan komunitas dan layanan kesehatan. Pada tingkatan kolaborasi, jalur komunikasi ini semakin erat dengan adanya database bersama. Layanan komunitas dan kesehatan yang berkolaborasi juga dapat menempati tempat yang sama untuk memudahkan komunikasi antar-layanan. Pada tingkat tertinggi, integrasi, maka penyediaan layanan kesehatan maupun komunitas terlibat dalam pengambilan keputusan klinis dalam layanan kesehatan.

Dalam pelaksanaan program, tingkat koordinasi dalam continuum of integration berarti adanya jalur komunikasi untuk penyediatahuan mengenai perencanaan dan pelaksanaan kegiatan terkait program masing-masing komponen. Pada tingkat kolaborasi, institusi komponen melakukan perencanaan dan evaluasi kegiatan program bersama. Kolaborasi juga berarti penyusunan standar operasi bersama dan penghimpunan sumber daya untuk dikelola bersama. Sementara itu, pada tingkat integrasi komponen-komponen bekerja dan melaksanakan program secara saling interdependen antara satu sama lain. Dalam tingkat ini, semua komponen yang terlibat tidak dapat merencanakan, menjalankan, menyelesaikan kegiatan secara mandiri tetapi harus disertai kontribusi dari komponen yang lain.

Analisis tingkat persetujuan terhadap model yang diusulkan. Dilakukan kodifikasi dan penjabaran deskriptif untuk profil partisipan, meliputi jenis kelamin, umur, organisasi afiliasi, dan pengalaman bekerja di bidang HIV. Persepsi mengenai pernyataan dalam metode Delphi sendiri dijabarkan dalam persentase. Presentase kesetujuan atau ketidak setujuan lebih dari atau sama dengan 95\% diinterpretasikan sebagai konsensus kuat, 75-94\% sebagai konsensus, 50-74\% sebagai mayoritas setuju/tidak setuju, dan kurang dari $50 \%$ sebagai tidak ada konsensus. Masukan-masukan yang 
diberikan para pakar dalam uraian singkat kemudian dijadikan bahan pertimbangan untuk revisi model penempatan komunitas dalam SKN.

\subsection{Hasil}

\subsubsection{Persetujuan Model Pada Survei Delphi Tahap 1}

Dari 77 orang pakar yang berhasil dihubungi melalui email dan pesan singkat pada survey Delphy Siklus I, sebanyak 55 orang mengisi survey sebagai responden dengan tingkat respon 74,3\%. Distribusi berdasarkan jenis kelamin terdiri atas 31 (56,4\%) laki-laki, 22 (41,8\%) perempuan, dan 1 $(1,8 \%)$ lainnya/gender non-biner dengan rerata usia 46,36 $( \pm 7,78)$ tahun dan rerata pengalaman professional dalam bidang HIV selama 14,07 ( \pm 7,32) tahun. Sebanyak 25 (45,5\%) orang berlatar belakang LSM/CBO, 13 (23,6\%) dari institusi pemerintahan, 11 (20\%) dari lembaga pembangunan internasional, dan $6(10,9 \%)$ dari lembaga riset universitas.

\section{Tingkat Persetujuan Terhadap Model Yang diusulkan}

Dalam Survey Siklus I diperoleh konsensus mengenai validitas ilmiah dari semua daftar kegiatan pelibatan peran serta komunitas dalam layanan terkait HIV dalam SKN. Akan tetapi, tidak semua kegiatan dinilai memenuhi kelayakan sesuai dengan kondisi di lapangan. Beberapa kegiatan partisipasi komunitas dalam layanan yang mencapai konsensus responden untuk diterapkan sesuai dengan kondisi di lapangan meliputi perekrutan dan pelatihan penjangkau, penjangkauan lapangan, tes HIV mobile, notifikasi pasangan, layanan pendampingan pasien, mobilisasi komunitas, dan koordinasi kebijakan dengan stakeholder. Walaupun tidak mencapai konsensus, mayoritas responden setuju implementasi partisipasi komunitas dalam penjangkauan digital, tes HIV berbasis komunitas, tes HIV mandiri berbasis komunitas, pengawasan minum obat, penyediaan dukungan psikososial berbasis kultur/agama, dan partisipasi komunitas dalam riset. Adapun implementasi distribusi ART berbasis komunitas masih menjadi kontroversi dan tidak mencapai dukungan mayoritas yang signifikan.

\section{Masukan Terhadap Model Layanan Komunitas}

Analisis tematik dilakukan untuk masukan-masukan yang diberikan responden dalam survey Siklus I. Hasilnya dijadikan landasan untuk revisi model partisipasi komunitas dalam layanan terkait HIV dalam SKN. Tema utama yang teridentifikasi dari masukan responden adalah perlunya perbaikan teknis pelaksanaan beberapa kegiatan partisipasi komunitas dalam layanan terutama dari segi peningkatan peran komunitas, peningkatan kualitas layanan, dan kebersinambungan penyediaan layanan yang berkualitas dengan partisipasi komunitas. Selain itu, untuk kegiatan yang belum pernah dilakukan di Indonesia, tema masukan terutama berpusat pada perlunya payung hukum untuk menaungi pelaksanaan kegiatan tersebut. Adapun tema-tema masukan utama yang dijadikan landasan revisi dari survei Siklus I adalah sebagai berikut: 
a. Klarifikasi Definisi Komunitas Yang Diutamakan Berpartisipasi Dalam Layanan Terkait HIV Dalam SKN

Responden menilai definisi komunitas dalam model masih lemah. Masukan diberikan mengenai keutamaan partisipasi dari kelompok terdampak HIV, meliputi populasi kunci HIV dan komunitas ODHIV yang terorganisasi dan aktif dalam memberikan layanan terkait HIV. Keutamaan partisipasi komunitas ini didasari perlunya penguatan kepercayaan dari anggota kelompok-kelompok terdampak HIV terhadap layanan yang dapat dikuatkan dengan partisipasi aktif dari komunitas dalam kerangka SKN.

b. Peningkatan Partisipasi Komunitas Dalam Perencanaan Program Layanan

Responden menilai model partisipasi masih merefleksikan kondisi saat ini di mana pekerja dari komunitas ditempatkan sebagai pelaksana dalam partisipasinya memberikan layanan terkait HIV. Kondisi ini dinilai sebagai kelemahan dan diperlukan penguatan sistem partisipasi dengan meningkatkan peran komunitas dalam perencanaan kegiatan dan program layanan terkait HIV.

c. Keutamaan Perekrutan Penjangkau Dari Komunitas Sasaran

Walaupun setuju mengenai perlunya penetapan standar kualifikasi minimal untuk perekrutan penjangkau dan pekerja layanan komunitas, responden memberi masukan mengenai pentingnya keutamaan perekrutan dari kalangan anggota komunitas sasaran, yaitu kelompok-kelompok terdampak HIV. Seperti disebutkan di atas, hal ini ditujukan untuk menguatkan rasa percaya terhadap layanan dalam kerangka SKN.

d. Standarisasi Dan Penguatan Kompetensi Penjangkau

Responden memberi masukan mengenai perlunya standarisasi kompetensi dasar penjangkau dan pekerja komunitas lainnya yang saat ini dikelola secara sporadis oleh berbagai organisasi di berbagai daerah. Selain itu, penguatan komptensi disarankan tidak hanya dilakukan di awal perekrutan tetapi juga diikuti dengan penguatan atau penyegaran berkala.

e. Pembagian Peran Layanan Kesehatan Dan Komunitas Dalam Layanan Diagnosis HIV Partisipasi dan peran komunitas dalam layanan diagnosis dan inisiasi terapi HIV menjadi sorotan bagi responden. Responden menekankan bahwa penegakkan diagnosis HIV harus dilakukan oleh tenaga kesehatan professional. Oleh karena itu, tes HIV jenis apapun yang dilakukan oleh layanan komunitas diposisikan sebagai screening atau penapisan awal.

f. Pembagian Peran Layanan Kesehatan Dan Komunitas Dalam Inisiasi Dan Dukungan Terapi Responden menekankan perlunya tenaga kesehatan professional sebagai pemeran utama, selain ODHIV itu sendiri, dalam manajemen terapi HIV. Walaupun mendukung integrasi partisipasi komunitas, responden menekankan bahwa komunitas sebaiknya ditempatkan sebagai layanan satelit yang mendukung manajemen terapi ART oleh tenaga kesehatan.

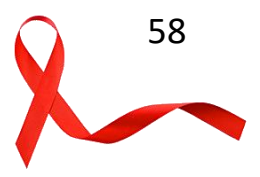




\section{g. Penguatan Sistem Pembiayaan Kegiatan Dengan Partisipasi Komunitas}

Responden menekankan pentingnya klarifikasi dan penguatan sistem pembiayaan kegiatan-kegiatan layanan dalam SKN dengan partisipasi komunitas. Hal ini dirasa penting terutama untuk item-item dalam model yang saat ini masih belum diimplementasikan di lapangan. Responden memberi masukan perlunya kejelasan mengenai sistem pembiayaan sebelum kegiatan-kegiatan ini dijalankan.

h. Penguatan sistem pencatatan, pelaporan, dan evaluasi kegiatan dengan partisipasi komunitas

Penekanan mengenai pentingnya sistem pencatatan, pelaporan, dan evaluasi kegiatan ditekankan responden terutama untuk kegiatan yang melibatkan diagnosis HIV dan ART. Pencatatan dan pelaporan, disertai komunikasi mengenai temuan kasus, dinilai penting dilakukan dalam kegiatan-kegiatan screening HIV di komunitas. Sementara itu, pencatatan dan pelaporan juga dinilai penting dilakukan dalam partisipasi komunitas mendukung ART.

\subsubsection{Revisi Model Penempatan Komunitas Dalam Survei Delphi Tahap 2}

Sebanyak 55 orang responden dari survey Siklus I dihubungi dan 41 orang menjawab dan berpartisipasi pada survey Delphi Siklus II dengan tingkat respon sebesar 74,5\%. Dari jumlah ini, sebanyak 26 responden berjenis kelamin laki-laki (63,4\%), 14 orang perempuan $(34,2 \%)$, dan 1 orang lainnya/gender non-biner (2,4\%). Rata-rata usia responden pada Siklus II adalah 48,13 \pm 7,58 tahun dengan rata-rata pengalaman kerja selama 12,73 $\pm 7,57$ tahun. Adapun latar belakang afiliasi responden masih didominasi LSM/CBO dengan 23 orang $(56,1 \%)$ diikuti oleh pemerintahan dengan 9 orang $(21,9 \%), 6$ orang $(14,6 \%)$ dari agensi pembangunan internasional, dan $3(7,3 \%)$ orang dari universitas dan lembaga riset. 
Tabel 6. Kesetujuan Responden Mengenai Kegiatan-Kegiatan Partisipasi Komunitas dalam Layanan HIV.

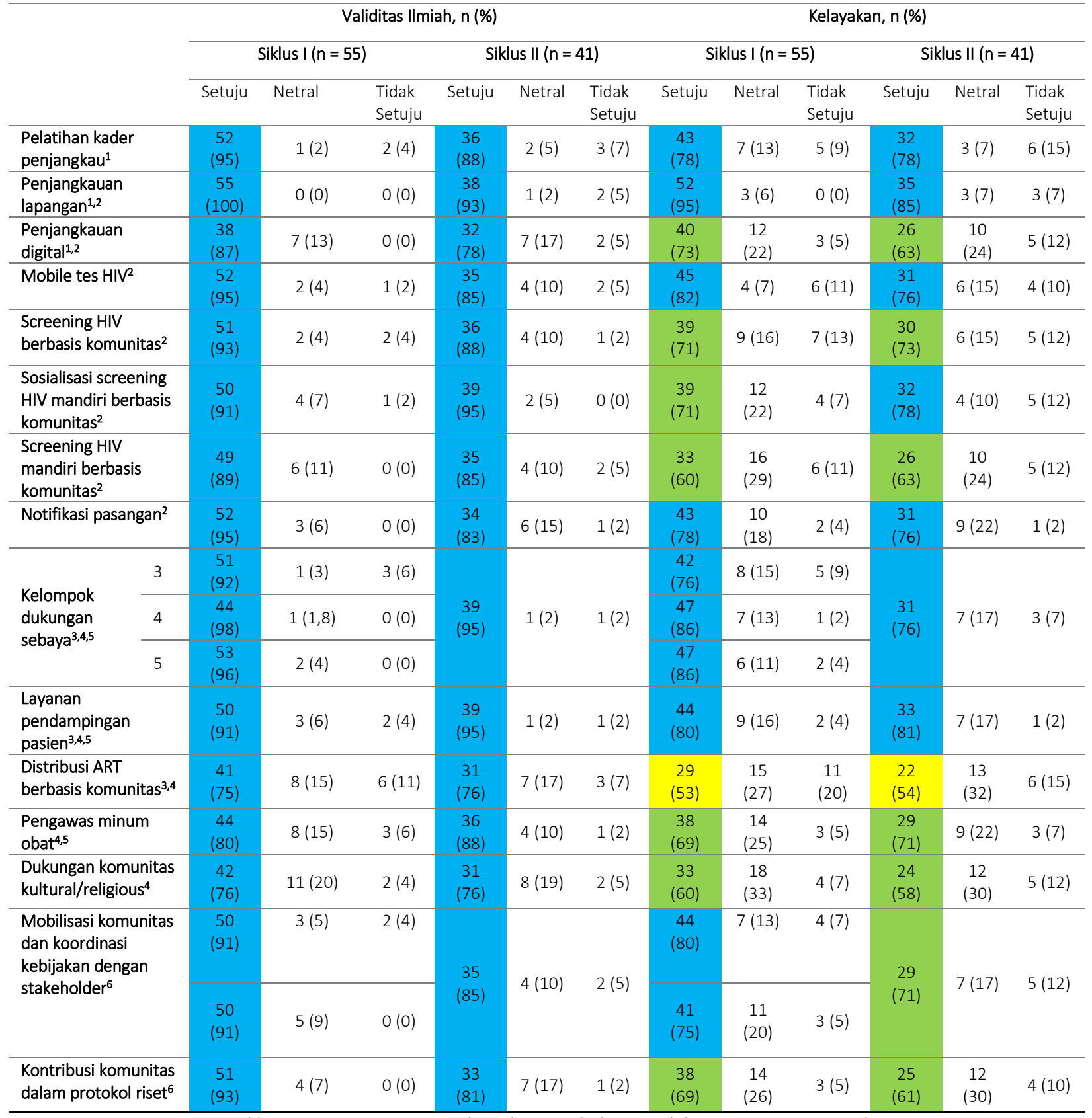

Keterangan I: Fungsi yang dilayani: ${ }^{1}$ Layanan pencegahan dan perubahan perilaku; ${ }^{2}$ Diagnosis cepat dan tepat; ${ }^{3}$ Inisiasi terapi; ${ }^{4}$ Dukungan retensi; ${ }^{5}$ Dukungan psikososial; ${ }^{6}$ Advokasi dan koordinasi dengan stakeholder lain

Keterangan II:

Konsensus

Dukungan mayoritas

Tidak ada konsensus

\subsubsection{Tingkat Persetujuan Terhadap Revisi Model Penempatan Komunitas}

Seperti dapat dilihat dalam Tabel 6, tidak ada perubahan tingkat konsensus validitas ilmiah pada survey Siklus I dan II. Semua kegiatan partisipasi komunitas yang diujikan dalam model ditemukan 
mencapai konsensus mengenai validitas ilmiah kegiatan-kegiatan tersebut. Akan tetapi, terdapat perubahan mengenai tingkat konsensus mengenai kelayakan sesuai dengan kondisi lapangan.

Satu kegiatan mengalami peningkatan tingkat konsensus dari dukungan kesetujuan mayoritas menjadi konsensus, yaitu sosialisasi skrining HIV mandiri berbasis komunitas. Sementara itu, satu kegiatan juga ditemukan mengalami penurunan konsensus kelayakan pada survei Siklus II ini, yaitu mobilisasi komunitas dan koordinasi kebijakan dengan stakeholder. Kegiatan ini ditemukan mengalami penurunan kelayakan dari konsensus menjadi dukungan mayoritas responden.

Satu item baru yang ditambahkan pada survey Siklus II adalah pertanyaan mengenai klarifikasi definisi dan dasar hukum keterlibatan pekerja komunitas dalam layanan kesehatan dalam kerangka SKN. Partisipasi komunitas saat ini diatur dalam PMK Nomor 8 tahun 2019 yang mengatur definisi, kualifikasi, tanggung jawab, dan peran kader serta tenaga pendamping. Adapun nomenklatur yang digunakan untuk pekerja komunitas terkait HIV beragam, mulai dari penjangkau lapangan, pendamping, dan lain-lain.

Tabel 7. Kesetujuan Responden mengenai Aturan Hukum yang Mengatur SDM Komunitas dalam Layanan terkait HIV $(n=41)$.

\begin{tabular}{llll}
\hline & Setuju & Netral & Tidak Setuju \\
\hline Pelatihan kader penjangkau $^{1}$ & $29(71)$ & $6(15)$ & $6(15)$ \\
\hline Penjangkauan lapangan $^{1,2}$ & $35(85)$ & $2(5)$ & $4(10)$ \\
\hline
\end{tabular}

Keterangan: $\quad$ Konsensus $\quad$ Dukungan mayoritas

Mengenai topik ini (Tabel 7), ditemukan adanya dukungan mayoritas mengenai penetapan PMK Nomor 8 tahun 2019 tersebut sebagai dasar utama manajemen sumber daya manusia (SDM) dari komunitas dalam layanan terkait HIV di Indonesia. Sementara itu, terdapat konsensus mengenai perlunya dikembangkan aturan khusus yang spesifik mengatur sumber daya manusia komunitas dalam layanan kesehatan terkait HIV.

\subsubsection{Masukan Mengenai Kegiatan}

\section{Perekrutan Dan Pelatihan Kader Penjangkau}

Tema utama masukan responden mengenai kegiatan ini adalah penekanan mengenai pentingnya standarisasi kualifikasi dan kompetensi dalam proses perekrutan penjangkau. Penetapan standar kualifikasi dan kompetensi ini disarankan untuk melibatkan komunitas melalui proses yang transparan. Selain itu, responden juga menekankan pentingnya manajemen sumber daya manusia dengan adanya penyegaran dan peningkatan kompetensi berkala bagi penjangkau yang sudah direkrut.

\section{Penjangkauan Lapangan}


Responden setuju mengenai pelibatan komunitas dalam kegiatan penjangkauan dengan beberapa memberi masukan untuk perbaikan. Tema utama masukan yang diberikan adalah perlunya standarisasi kapasitas penjangkau antar-organisasi komunitas dan antara-daerah. Selain itu juga disarankan pembentukan petunjuk teknis dan algoritma mengenai standar layanan yang diberikan penjangkau. Tema lain yang dapat diidentifikasi adalah perlunya penguatan sistem pembiayaan.

\section{Penjangkauan Digital}

Responden setuju mengenai validitas teori dan potensi pendekatan ini. Masukan yang masuk terutama menyasar kesiapan populasi sasaran, tenaga penjangkau, dan sistem evaluasi. Responden mengidentifikasi tidak meratanya penggunaan internet pada populasi kunci sasaran penjangkauan sebagai penghambat maksimalisasi manfaat dari pendekatan ini. Begitu pula dengan tidak meratanya kemampuan penggunaan teknologi informasi oleh penjangkau. Masukan juga diberikan mengenai perlunya penyusunan sistem pencatatan dan pelaporan capaian dari penjangkauan digital ini sebelum dilaksanakan.

\section{Tes HIV Mobile}

Tes HIV mobile disetujui responden berjalan dengan baik dalam kondisi saat ini dengan beberapa catatan. Pendekatan ini dinilai tidak dapat dilakukan untuk semua daerah atau semua populasi kunci dan paling sesuai diterapkan untuk populasi kunci yang terpusat secara geografi, seperti populasi pekerja seks langsung. Selain itu, responden memberi masukan mengenai perlunya pelibatan komunitas untuk mencegah lost to follow up yang sering terjadi pada penerima tes HIV mobile.

\section{Skrining HIV Berbasis Komunitas}

Beberapa tema masukan responden mengenai kegiatan ini adalah penguatan kapasitas konseling pekerja komunitas pelaksana screening dan juga penguatan sistem rujukan ke layanan kesehatan. Kedua hal ini diperlukan untuk antisipasi kebutuhan penerima screening, baik kebutuhan dukungan psikososial maupun kebutuhan layanan kesehatan lebih lanjut.

\section{Sosialisasi Skrining HIV mandiri berbasis komunitas}

Masukan responden mengenai kegiatan ini umumnya mengutarakan kesetujuan dengan penekanan pentingnya aksesibilitas bahasa dalam pelaksanaan sosialisasi. Konten sosialisasi diharapkan dibuat dalam bahasa yang sederhana dan mudah dimengerti populasi sasaran. Hal ini sudah tertuang dalam model revisi dalam survey Siklus II.

\section{Skrining HIV Mandiri Berbasis Komunitas}

Tema utama masukan responden untuk kegiatan ini adalah perlunya peraturan perundangan yang meregulasi screening HIV mandiri yang saat ini belum teregulasi. Berkaitan dengan itu, masukan juga diberikan mengenai perlunya pengembangan standar operasi pelaksanaan 
screening HIV mandiri dan tindak lanjut yang perlu dilakukan pekerja komunitas bagi penerima screening mandiri tersebut.

\section{Notifikasi Pasangan}

Masukan responden mengenai kegiatan ini terutama menekankan perlunya peningkatan kapasitas penjangkau dan pekerja komunitas lainnya dalam memberikan konseling dan edukasi layanan notifikasi pasangan. Menurut responden peningkatan kapasitas terutama diperlukan terkait dengan pencegahan kejadian tidak diinginkan dari notifikasi pasangan, seperti kebocoran konfidensialitas atau kekerasan dalam rumah tangga.

\section{Kelompok Dukungan Sebaya}

Tema utama masukan responden mengenai KDS adalah kesetujuan mengenai sifatnya yang multifungsi. KDS dinilai berpotensi melayani anggota sebagai dukungan psikososial, agen perubahan perilaku terkait pencegahan, dan juga dukungan retensi pengobatan.

\section{Layanan Pendampingan Pasien}

Responden setuju mengenai pelaksanaan layanan pendampingan pasien dengan partisipasi komunitas. Masukan diberikan mengenai perlunya pembekalan petugas pendamping pasien, terutama penguatan kapasitas konseling dan edukasi. Selain itu, sebagian kecil responden juga memberi masukan mengenai potensi penggabungan kegiatan ini dalam layanan kelompok dukungan sebaya.

\section{Layanan Pengawas Minum Obat}

Terdapat tiga tema utama mengenai pelaksanaan kegiatan ini dengan partisipasi komunitas. Pertama, walaupun responden setuju mengenai potensi partisipasi komunitas dalam kegiatan ini, responden menyatakan bahwa peran ini utamanya dipegang oleh keluarga pasien. Oleh karena itu komunitas sebaiknya mengambil peran ini hanya untuk sementara waktu, bagi ODHIV yang baru terdiagnosis dan belum terbuka dengan keluarga. Kedua, terdapat responden yang berpendapat bahwa pelaksanaan kegiatan ini oleh komunitas dapat digabungkan dengan layanan kelompok dukungan sebaya.

\section{Distribusi ART Berbasis Komunitas}

Tidak terdapat konsensus responden mengenai masukan yang diberikan terkait kegiatan ini. Masukan responden terbagi menjadi beberapa tema utama. Beberapa responden berpendapat adanya ketidaksesuaian kapasitas komunitas dalam pendistribusian dan pengawasan pengobatan pada pasien. Responden lain melihat potensi dari pendekatan ini tetapi menekankan perlunya mekanisme pengawasan, pencatatan, dan evaluasi yang kuat untuk menjamin ART mencapai target dan diminum dengan semestinya.

\section{Dukungan Psikososial Berbasis Kultur/Agama}

Responden umumnya setuju bahwa layanan ini dapat diberikan atas basis on demand atau atas perminataan klien, di mana komunitas dapat menjadi penghubung dan pengawas layanan 
psikososial berbasis kultur/agama agar sensitive terhadap identitias dan isu populasi kunci. Akan tetapi, responden juga berpendapat bahwa implementasi nyata dari teori ini sulit dilakukan di Indonesia di mana organisasi agama umumnya menunjukkan penolakan terhadap sebagaian besar populasi kunci seperti laki-laki yang berhubungan seks dengan laki-laki, pekerja seks, dan waria.

\section{Mobilisasi Komunitas Dan Koordinasi Kebijakan}

Responden setuju dengan partisipasi komunitas dalam koordinasi kebijakan dengan didasari mobiliasi komunitas. Responden memberi masukan mengenai pentingnya partisipasi aktif dan bermakna dari komunitas. Kondisi saat ini dinilai bermasalah di mana partisipasi komunitas dinilai masih sebatas seremonial dan tidak efektif menghasilkan perubahan kebijakan bermakna.

\section{Partisipasi Dalam Penelitian}

Responden menilai ada potensi besar dari keterlibatan komunitas dalam penelitian terkait HIV. Layanan-layanan komunitas dinilai banyak memiliki data berharga mengenai pembelajaran terkait pelaksanaan layanan HIV di Indonesia. Akan tetapi, peningkatan kapasitas komunitas dalam perencanaan dan pelaksanaan penelitian menjadi syarat yang harus terpenuhi sebelum potensi ini dapat dimanfaatkan dengan maksimal.

\subsubsection{Pembahasan dan Rekomendasi Model}

Survei Delphi Siklus I dan II memvalidasi keilmiahan temuan tinjauan pustaka sistematik mengenai kegiatan-kegiatan partisipasi komunitas dalam layanan terkait HIV yang dapat diintegrasikan dalam SKN. Akan tetapi, implementasi model ini tetap harus memperhatikan kondisi di lapangan yang unik untuk setiap negara. Oleh karena itu, rekomendasi implementasi model partisipasi peran komunitas dalam layanan terkait HIV diklasifikasikan menjadi rekomendasi jangka pendek dan rekomendasi jangka panjang, terkait dengan penilaian kelayakan implementasi model kegiatan tersebut sesuai dengan kondisi di lapangan menurut responden survey Delphi.

Klasifikasi rekomendasi jangka pendek dan jangka panjang dilakukan berdasarkan konsensus kelayakan kegiatan sesuai dengan kondisi di lapangan dalam survei tahap 2. Untuk kegiatankegiatan yang mencapai konsensus, disimpulkan bahwa kegiatan tersebut direkomendasikan untuk diimplementasikan dalam jangka pendek. Sementara itu, kegiatan yang mencapai dukungan mayoritas disimpulkan untuk direkomendasikan dalam jangka panjang. Adapun kegiatan yang tidak mencapai konsensus, diarahkan untuk tidak diimplementasikan terlebih dahulu, tetapi harus dilakukan persiapan dan penelitian lebih lanjut, sesuai dengan masukan dari responden.

Sebagian besar kegiatan yang mencapai konsensus dan direkomendasikan untuk implementasi jangka pendek merupakan kegiatan-kegiatan yang saat ini sudah dilaksanakan dengan partisipasi komunitas yang bervariasi, seperti perekrutan penjangkau, penjangkauan lapangan, tes HIV 
mobile, dan pendampingan pasien. Beberapa kegiatan baru yang direkomendasikan untuk implementasi jangka pendek adalah sosiaisasi screening HIV mandiri berbasisi komunitas dan notifikasi pasangan.

Implementasi penjangkauan digital, screening HIV berbasis komunitas, layanan pengawasan minum obat berbasis komunitas, dan koordinasi dukungan psikososial berbasis kultur/agama dinilai belum memenuhi kelayakan untuk diimplementasikan dalam jangka pendek. Masukan responden menunjukkan adanya persepsi mengenai perlunya persiapan kebijakan maupun organisasi komunitas sebelum kegiatan-kegiatan tersebut dapat diimplementasikan.

Model akhir yang dirumuskan untuk partisipasi komunitas dalam layanan terkait HIV dalam kerangka SKN merupakan model yang disetujui dalam survey Delphi tahap 2. Satu kasus kegiatan yang mencapai konsensus pada survey Siklus I tetapi turun menjadi dukungan mayoritas pada survey tahap 2 dapat tetap direkomendasikan untuk implementasi jangka pendek, dengan perubahan model di mana model yang dapat diimplementasikan adalah model yang diajukan dalam survey tahap 1. Model ini dapat dilihat dalam tabel berikut: 
Tabel 8. Model Akhir Partisipasi Komunitas dalam SKN menurut Masukan Responden dalam Pengumpulan Data Delphi Siklus I dan II

\begin{tabular}{|c|c|c|c|c|}
\hline \multirow{2}{*}{$\begin{array}{l}\text { Kegiatan Keterlibatan } \\
\text { Komunitas }\end{array}$} & \multirow{2}{*}{$\begin{array}{c}\text { Tingkat } \\
\text { Integrasi }\end{array}$} & \multirow[t]{2}{*}{ Kegiatan Integrasi } & \multicolumn{2}{|r|}{ Peran } \\
\hline & & & Layanan Kesehatan & Komunitas \\
\hline $\begin{array}{l}\text { Penjangkauan } \\
\text { lapangan }^{1,2}\end{array}$ & Integrasi & $\begin{array}{l}\text { - Mengembangkan sistem rujukan bagi populasi } \\
\text { terjangkau } \\
\text { - Mengembangkan sistem pembiayaan gabungan dari } \\
\text { anggaran pemerintah dan komunitas } \\
\text { - Identifikasi topik dan penyusunan modul edukasi } \\
\text { perubahan perulaku } \\
\text { - Mengembangkan sistem penjangkauan lapangan yang } \\
\text { menjaga konfidensialitas } \\
\text { - Mengembangkan sistem perujukan/penyerahan klien } \\
\text { dari penjangkau ke layanan pendampingan } \\
\text { pengobatan ART }\end{array}$ & $\begin{array}{l}\text { - Mengembangkan modul } \\
\text { edukasi perubahan perilaku } \\
\text { - Menerima dan menindak } \\
\text { lanjuti rujukan populasi } \\
\text { risiko tinggi } \\
\text { - Memfasilitasi penyerahan } \\
\text { pasien dari penjangkau ke } \\
\text { pendamping pengobatan }\end{array}$ & $\begin{array}{l}\text { - Memetakan sasaran penjangkauan } \\
\text { untuk luaran maksimal } \\
\text { - Mengembangkan modul edukasi } \\
\text { perubahan perilaku } \\
\text { - Melaksanakan penjangkauan } \\
\text { - Merujuk populasi risiko tinggi yang } \\
\text { terjangkau } \\
\text { - Terlibat dalam proses penyerahan } \\
\text { pasien terdiagnosis ke layanan dan } \\
\text { pendamping pengobatan }\end{array}$ \\
\hline Penjangkauan digital ${ }^{1,2}$ & Integrasi & $\begin{array}{l}\text { - Mengembangkan sistem penjangkauan digital yang } \\
\text { menjaga konfidensialitas } \\
\text { - Mengembangkan sistem rujukan melalui platform } \\
\text { penjangkauan digital } \\
\text { - Mengembangkan sistem pembiayaan gabungan dari } \\
\text { anggaran pemerintah dan komunitas }\end{array}$ & $\begin{array}{l}\text { - Menerima rujukan kasus } \\
\text { berisiko tinggi yang } \\
\text { terjangkau } \\
\text { - Mengembangkan konten } \\
\text { edukasi }\end{array}$ & $\begin{array}{l}\text { - Mengembangkan konten edukasi } \\
\text { - Melaksanakan penjangkauan dan } \\
\text { edukasi } \\
\text { - Merujuk kasus yang teridentifikasi } \\
\text { berisiko tinggi }\end{array}$ \\
\hline Mobile tes HIV² & Integrasi & $\begin{array}{l}\text { - Perencanaan kegiatan } \\
\text { - Mengembangkan sistem pembiayaan gabungan dari } \\
\text { anggaran pemerintah dan komunitas } \\
\text { - Penyusunan standar operasi tes HIV } \\
\text { - Pengelolaan sumber daya }\end{array}$ & $\begin{array}{l}\text { - Terlibat dalam perencanaan } \\
\text { dan penyusunan standar } \\
\text { operasi tes HIV yang tepat } \\
\text { secara klinis }\end{array}$ & $\begin{array}{l}\text { - Terlibat dalam perencanaan dan } \\
\text { penyusunan standar operasi tes HIV } \\
\text { yang diterima komunitas } \\
\text { - Pemetaan titik panas untuk lokasi } \\
\text { tes mobile }\end{array}$ \\
\hline
\end{tabular}




\begin{tabular}{|c|c|c|c|c|}
\hline & & $\begin{array}{l}\text { - Evaluasi program } \\
\text { - Pemetaan titik panas untuk tes HIV } \\
\text { - Membuka jalur pelayanan bagi populasi kunci yang } \\
\text { terdiagnosis HIV }\end{array}$ & $\begin{array}{l}\text { - Penyediaan SDM tenaga } \\
\text { kesehatan } \\
\text { - Penyediaan HIV test kit } \\
\text { - Melakukan konfirmasi } \\
\text { diagnosis HIV }\end{array}$ & $\begin{array}{l}\text { - Mobilisasi komunitas di titik panas } \\
\text { untuk menerima tes HIV }\end{array}$ \\
\hline $\begin{array}{l}\text { Skrining HIV berbasis } \\
\text { komunitas }^{2}\end{array}$ & Integrasi & $\begin{array}{l}\text { - Perencanaan kegiatan } \\
\text { - Mengembangkan sistem pembiayaan gabungan dari } \\
\text { anggaran pemerintah dan komunitas } \\
\text { - Penyusunan standar operasi tes HIV } \\
\text { - Pengelolaan sumber daya } \\
\text { - Evaluasi program } \\
\text { - Membuka jalur pelayanan bagi populasi kunci yang } \\
\text { terdiagnosis HIV }\end{array}$ & $\begin{array}{l}\text { - Terlibat dalam perencanaan } \\
\text { dan penyusunan standar } \\
\text { operasi tes HIV yang tepat } \\
\text { secara klinis } \\
\text { - Penyediaan HIV test kit } \\
\text { - Menerim arujukan dan } \\
\text { melakukan konfirmasi } \\
\text { diagnosis HIV }\end{array}$ & $\begin{array}{l}\text { - Terlibat dalam perencanaan dan } \\
\text { penyusunan operasi standar tes HIV } \\
\text { yang bisa diterima komunitas } \\
\text { - Pemetaan kebutuhan sumber daya } \\
\text { - Menyediakan sumber daya manusia } \\
\text { yang akan dilatih sebagai pelaksana } \\
\text { skrining } \\
\text { - Mobilisasi komunitas untuk } \\
\text { menerima tes HIV } \\
\text { - Merujuk populasi kunci yang } \\
\text { terjaring dalam skrining }\end{array}$ \\
\hline $\begin{array}{l}\text { Sosialisasi skrining HIV } \\
\text { mandiri berbasis } \\
\text { komunitas }^{2}\end{array}$ & Kolaborasi & $\begin{array}{l}\text { - Perencanaan kegiatan } \\
\text { - Mengembangkan sistem pembiayaan kegiatan } \\
\text { terkoordinasi dengan anggaran pemerintah dan } \\
\text { komunitas membiayai peran dan komponen masing- } \\
\text { masing secara sinergis } \\
\text { - Penyusunan modul sosialisasi dan edukasi tes mandiri } \\
\text { dengan bahasa yang mudah dipahami populasi sasaran } \\
\text { - Evaluasi program }\end{array}$ & $\begin{array}{l}\text { - Menyusun modul sosialisasi } \\
\text { dan edukasi bersama } \\
\text { komunitas } \\
\text { - Menjadi tenaga ahli dalam } \\
\text { sosialisasi dan edukasi tes } \\
\text { mandiri } \\
\text { - Menyiapkan tanggapan atas } \\
\text { respon dan persepsi } \\
\text { komunitas tentang tes HIV } \\
\text { mandiri }\end{array}$ & $\begin{array}{l}\text { - Menyusun modul sosialisasi dan } \\
\text { edukasi yang bisa diterima } \\
\text { komunitas } \\
\text { - Menyederhanakan bahasa teknis } \\
\text { dalam modul edukasi dan sosialisasi } \\
\text { - Mobilisasi anggota komunitas untuk } \\
\text { menghadiri sosialisasi dan edukasi } \\
\text { tentang tes mandiri } \\
\text { - Mengevaluasi respon dan persepsi } \\
\text { komunitas tentang tes HIV mandiri }\end{array}$ \\
\hline $\begin{array}{l}\text { Skrining HIV mandiri } \\
\text { berbasis komunitas }^{2}\end{array}$ & Integrasi & $\begin{array}{l}\text { - Perencanaan kegiatan } \\
\text { - Mengembangkan sistem pembiayaan gabungan dari } \\
\text { anggaran pemerintah dan komunitas } \\
\text { - Penyusunan standar operasi untuk diagnosis HIV } \\
\text { dengan tes mandiri } \\
\text { - Pemetaan dan pengelolaan sumber daya } \\
\text { - Membuka jalur pelayanan bagi populasi kunci yang } \\
\text { terdiagnosis HIV } \\
\text { - Evaluasi program }\end{array}$ & $\begin{array}{l}\text { - Terlibat dalam perencanaan } \\
\text { dan penyusunan standar } \\
\text { operasi tes HIV mandiri } \\
\text { yang tepat secara klinis } \\
\text { - Penyediaan SDM tenaga } \\
\text { kesehatan } \\
\text { - Penyediaan HIV test kit } \\
\text { - Melakukan konfirmasi } \\
\text { diagnosis HIV }\end{array}$ & $\begin{array}{l}\text { - Terlibat dalam perencanaan dan } \\
\text { penyusunan operasi standar tes HIV } \\
\text { mandiri yang bisa diterima } \\
\text { komunitas } \\
\text { - Menyalurkan kit tes mandiri pada } \\
\text { anggota komunitas dan melakukan } \\
\text { follow up untuk hasilnya } \\
\text { - Mengedukasi dan mendampingi } \\
\text { penerima tes HIV mandiri } \\
\text { - Merujuk anggota komunitas yang } \\
\text { melaporkan hasil positif }\end{array}$ \\
\hline
\end{tabular}




\begin{tabular}{|c|c|c|c|c|}
\hline Notifikasi pasangan² & Integrasi & $\begin{array}{l}\text { - Penyusunan standar operasi notifikasi pasangan yang } \\
\text { melindungi konfidensialitas peserta } \\
\text { - Mengembangkan sistem pembiayaan gabungan dari } \\
\text { anggaran pemerintah dan komunitas } \\
\text { - Penyusunan sistem pencegahan dan mitigasi risiko } \\
\text { dampak negatif bagi penerima layanan notifikasi } \\
\text { pasangan } \\
\text { - Pengembangan database dan evaluasi program } \\
\text { bersama }\end{array}$ & $\begin{array}{l}\text { - Menyusun standar operasi } \\
\text { bersama komunitas yang } \\
\text { efektif berdasarkan bukti } \\
\text { dalam literatur } \\
\text { - Merekrut dan melatih } \\
\text { tenaga kesehatan untuk } \\
\text { melakukan konseling } \\
\text { notifikasi pasangan } \\
\text { - Mencatat dan melaporkan } \\
\text { luaran } \\
\text { - Evaluasi bersama dengan } \\
\text { komunitas }\end{array}$ & $\begin{array}{l}\text { - Menyusun standar operasi bersama } \\
\text { layanan yang dapat diterima } \\
\text { anggota komunitas } \\
\text { - Merekrut dan melatih penjangkau } \\
\text { dan pendamping sebaya untuk } \\
\text { melakukan notifikasi pasangan } \\
\text { - Mencatat dan melaporkan luaran } \\
\text { - Evaluasi bersama dengan layanan }\end{array}$ \\
\hline $\begin{array}{l}\text { Kelompok dukungan } \\
\text { sebaya } 3,4,5\end{array}$ & Integrasi & $\begin{array}{l}\text { - Penyusunan modul standar operasi untuk mendukung } \\
\text { kepatuhan berobat } \\
\text { - Mengembangkan sistem pembiayaan gabungan dari } \\
\text { anggaran pemerintah dan komunitas } \\
\text { - Jaluran saling rujuk pasien untuk terapi ART dan } \\
\text { dukungan komunitas } \\
\text { - Saluran rujukan dari komunitas untuk layanan } \\
\text { kesehatan mental } \\
\text { - Advokasi kepentingan komunitas untuk bersama } \\
\text { standar operasi layanan kesehatan yang inklusif }\end{array}$ & $\begin{array}{l}\text { - Menyusun modul standar } \\
\text { operasi untuk mendukung } \\
\text { kepatuhan berobat } \\
\text { bersama komunitas } \\
\text { - Mengembangkan standar } \\
\text { operasi layanan yang } \\
\text { inklusif berdasarkan } \\
\text { masukan komunitas } \\
\text { - Penyediaan terapi ART } \\
\text { - Arahkan pasien yang untuk } \\
\text { menerima dukungan } \\
\text { komunitas }\end{array}$ & $\begin{array}{l}\text { - Memberi dukungan psikososial } \\
\text { selama pasien menjalani } \\
\text { pengobatan } \\
\text { - Mengadvokasikan standar operasi } \\
\text { pelayanan inklusif bersama layanan } \\
\text { kesehatan } \\
\text { - Memberikan ruang aman dan sistem } \\
\text { dukungan (support system) sebagai } \\
\text { bentuk dukungan psikososial bagi } \\
\text { ODHIV dan populasi kunci } \\
\text { - Mengidentifikasi dan merujuk } \\
\text { anggota yang perlu layanan } \\
\text { dukungan berobat } \\
\text { - Mengidentifikasi dan merujuk } \\
\text { anggota yang perlu layanan } \\
\text { kesehatan mental profesional }\end{array}$ \\
\hline $\begin{array}{l}\text { Layanan } \\
\text { pendampingan } \\
\text { pasien }^{3,4,5}\end{array}$ & Integrasi & $\begin{array}{l}\text { - Penyusunan standar operasi layanan kesehatan yang } \\
\text { mudah dimengerti pasien dan komunitas } \\
\text { - Mengembangkan sistem pembiayaan gabungan dari } \\
\text { anggaran pemerintah dan komunitas } \\
\text { - Menyediakan jalur komunikasi bagi komunitas untuk } \\
\text { membantu pasien menavigasi sistem layanan } \\
\text { kesehatan } \\
\text { - Menyusun sistem pengawasan minum obat yang } \\
\text { membangun kemandirian pasien }\end{array}$ & $\begin{array}{l}\text { - Penyusunan standar operasi } \\
\text { layanan HIV bersama } \\
\text { komunitas } \\
\text { - Menyediakan saluran } \\
\text { komunikasi untuk } \\
\text { membantu pasien dan } \\
\text { pendamping komunitas }\end{array}$ & $\begin{array}{l}\text { - Penyusunan standar operasi layanan } \\
\text { HIV bersama layanan kesehatan } \\
\text { - Menyediakan pendamping yang } \\
\text { membantu pasien menavigasi } \\
\text { sistem layanan HIV } \\
\text { - Menerima pasien yang diserahkan } \\
\text { dari layanan penjangkau ke layanan } \\
\text { pendamping pengobatan }\end{array}$ \\
\hline
\end{tabular}




\begin{tabular}{|c|c|c|c|c|}
\hline & & $\begin{array}{l}\text { - Menyiapkan SDM terlatih dari populasi sebaya yang } \\
\text { cakap memberikan pendampingan berobat pada } \\
\text { pasien } \\
\text { - Mengembangkan sistem rujukan/penyerahan pasien } \\
\text { dari layanan penjangkau ke layanan pendamping } \\
\text { pengobatan }\end{array}$ & $\begin{array}{l}\text { - Melakukan pelatihan } \\
\text { intensif untuk SDM } \\
\text { pendamping } \\
\text { - Memfasilitasi penyerahan } \\
\text { pasien dari penjangkau ke } \\
\text { pendamping pengobatan } \\
\text { - Memberikan konseling dan } \\
\text { dukungan psikososial pada } \\
\text { pasien yang tidak taat } \\
\text { minum obat bersama } \\
\text { layanan }\end{array}$ & $\begin{array}{l}\text { - Merekrut sumber daya manusia } \\
\text { yang sesuai kriteria } \\
\text { - Memberikan konseling dan } \\
\text { dukungan psikososial pada pasien } \\
\text { yang tidak taat minum obat bersama } \\
\text { layanan }\end{array}$ \\
\hline $\begin{array}{l}\text { Layanan pengawas } \\
\text { minum obat }\end{array}$ & Integrasi & $\begin{array}{l}\text { - Penyusunan standar operasi yang efektif dan dapat } \\
\text { diterima komunitas } \\
\text { - Mengembangkan sistem pembiayaan kegiatan } \\
\text { terkoordinasi dengan anggaran pemerintah dan } \\
\text { komunitas membiayai peran dan komponen masing- } \\
\text { masing secara mandiri } \\
\text { - Perekrutan dan pelatihan pengawas minum obat dari } \\
\text { keluarga } \\
\text { - Mengembangkan sistem untuk menyediakan } \\
\text { pengawas minum obat dari komunitas atas } \\
\text { permintaan pasien } \\
\text { - Membuka jalur komunikasi untuk kasus-kasus } \\
\text { kepatuhan minum obat yang rendah } \\
\text { - Evaluasi program bersama }\end{array}$ & $\begin{array}{l}\text { - Menyusun standar operasi } \\
\text { yang efektif sesuai bukti } \\
\text { bersama komunitas } \\
\text { - Melatih pengawas minum } \\
\text { obat } \\
\text { - Menangani pasien yang } \\
\text { tidak taat minum obat } \\
\text { bersama komunitas }\end{array}$ & $\begin{array}{l}\text { - Menyusun standar operasi yang } \\
\text { dapat diterima komunitas bersama } \\
\text { layanan } \\
\text { - Mensosialisasikan dan merekrut } \\
\text { pengawas minum obat dari keluarga } \\
\text { pasien } \\
\text { - Menyediakan pengawas minum } \\
\text { obat dari komunitas atas } \\
\text { permintaan pasien } \\
\text { - Menangani pasien yang tidak taat } \\
\text { minum obat bersama layanan }\end{array}$ \\
\hline $\begin{array}{l}\text { Dukungan komunitas } \\
\text { kultural/religious }{ }^{5}\end{array}$ & Kolaborasi & $\begin{array}{l}\text { - Mengembangkan sistem kerja sama antara layanan } \\
\text { kesehatan, lembaga keagamaan, dan organisasi } \\
\text { komunitas dalam memberikan layanan psikososial } \\
\text { - Penyusunan bersama standar operasi dukungan } \\
\text { psikososial oleh lembaga agama yang sensitif identitas } \\
\text { budaya/agama } \\
\text { - Saluran rujukan dari layanan ke komunitas untuk } \\
\text { dukungan psikososial } \\
\text { - Saluran rujukan dari komunitas untuk layanan } \\
\text { kesehatan mental }\end{array}$ & $\begin{array}{l}\text { - Menyusun standar operasi } \\
\text { pelayanan sensitif identitas } \\
\text { budaya dan agama di } \\
\text { layanan kesehatan dan } \\
\text { komunitas } \\
\text { - Menyediakan informasi dan } \\
\text { saluran perujukan ke } \\
\text { lembaga agama untuk } \\
\text { dukungan spiritual atas } \\
\text { permintaan individual } \\
\text { pasien }\end{array}$ & $\begin{array}{l}\text { - Menyusun standar operasi } \\
\text { pelayanan sensitive identitas } \\
\text { budaya/agama di layanan kesehatan } \\
\text { dan komunitas } \\
\text { - Memberikan ruang aman dan sistem } \\
\text { dukungan (support system) sebagai } \\
\text { bentuk dukungan psikososial bagi } \\
\text { ODHIV dan populasi kunci } \\
\text { - Mengidentifikasi dan merujuk } \\
\text { anggota yang perlu layanan } \\
\text { kesehatan mental professional }\end{array}$ \\
\hline
\end{tabular}




\begin{tabular}{|c|c|c|c|c|}
\hline & & $\begin{array}{l}\text { - Saluran rujukan dari layanan dan komunitas ke } \\
\text { lembaga agama untuk dukungan spiritual atas } \\
\text { permintaan individual } \\
\text { - Saluran rujukan dari lembaga agama/kultur ke layanan } \\
\text { kesehatan untuk perawatan kesehatan fisik/mental } \\
\text { atas permintaan individual } \\
\text { - Saluran rujukan dari lembaga agama/kultur ke } \\
\text { komunitas untuk dukungan sebaya atas permintaan } \\
\text { individual }\end{array}$ & & $\begin{array}{l}\text { - Menyediakan informasi dan saluran } \\
\text { perujukan ke lembaga agama untuk } \\
\text { dukungan spiritual atas permintaan } \\
\text { individual pasien }\end{array}$ \\
\hline Mobilisasi komunitas & Kolaborasi & $\begin{array}{l}\text { - Perencanaan kegiatan bersama } \\
\text { - Identifikasi topik dan penyusunan modul bersama } \\
\text { - Evaluasi bersama }\end{array}$ & $\begin{array}{l}\text { - Menyusun modul pelatihan } \\
\text { dan edukasi sesuai } \\
\text { identifikasi topik dari } \\
\text { komunitas } \\
\text { - Memberi pelatihan sebagai } \\
\text { tenaga ahli }\end{array}$ & $\begin{array}{l}\text { - Mengidentifikasi topik edukasi yang } \\
\text { urgen bagi komunitas } \\
\text { - Mobilisasi komunitas untuk } \\
\text { mendapat edukasi }\end{array}$ \\
\hline $\begin{array}{l}\text { Koordinasi kebijakan } \\
\text { dengan stakeholder }\end{array}$ & Kolaborasi & - Mengidentifikasi isu prioritas bersama secara rutin & $\begin{array}{l}\text { - Mengidentifikasi dan } \\
\text { menyuarakan isu prioritas } \\
\text { bersama komunitas }\end{array}$ & $\begin{array}{l}\text { - Mengidentifikasi dan menyuarakan } \\
\text { isu prioritas bersama layanan } \\
\text { kesehatan }\end{array}$ \\
\hline $\begin{array}{l}\text { Kontribusi komunitas } \\
\text { dalam protokol riset }{ }^{6}\end{array}$ & Kolaborasi & $\begin{array}{l}\text { - Menyusun protokol penelitian bersama dengan } \\
\text { menampung perspektif komunitas }\end{array}$ & $\begin{array}{l}\text { - Menyusun protokol } \\
\text { penelitian yang tepat } \\
\text { menurut metodologi ilmiah }\end{array}$ & $\begin{array}{l}\text { - Menyusun sistem crowdsourcing } \\
\text { untuk menampung perspektif } \\
\text { komunitas } \\
\text { - Memberi masukan dalam protokol } \\
\text { penelitian sesuai perspektif } \\
\text { komunitas }\end{array}$ \\
\hline \multicolumn{5}{|c|}{$\begin{array}{l}\text { Fungsi yang dilayani: }{ }^{1} \text { Layanan pencegahan dan perubahan perilaku; }{ }^{2} \text { Diagnosis cepat dan tepat; }{ }^{3} \text { nisiasi terapi; }{ }^{4} \text { Dukungan retensi; }{ }^{5} \text { Dukungan psikososial; }{ }^{6} \mathrm{Advokasi} \\
\text { dan koordinasi dengan stakeholder lain }\end{array}$} \\
\hline Keterangan: & & Rekomendasi jangka pendek & \multicolumn{2}{|c|}{ Rekomendasi jangka panjang } \\
\hline
\end{tabular}




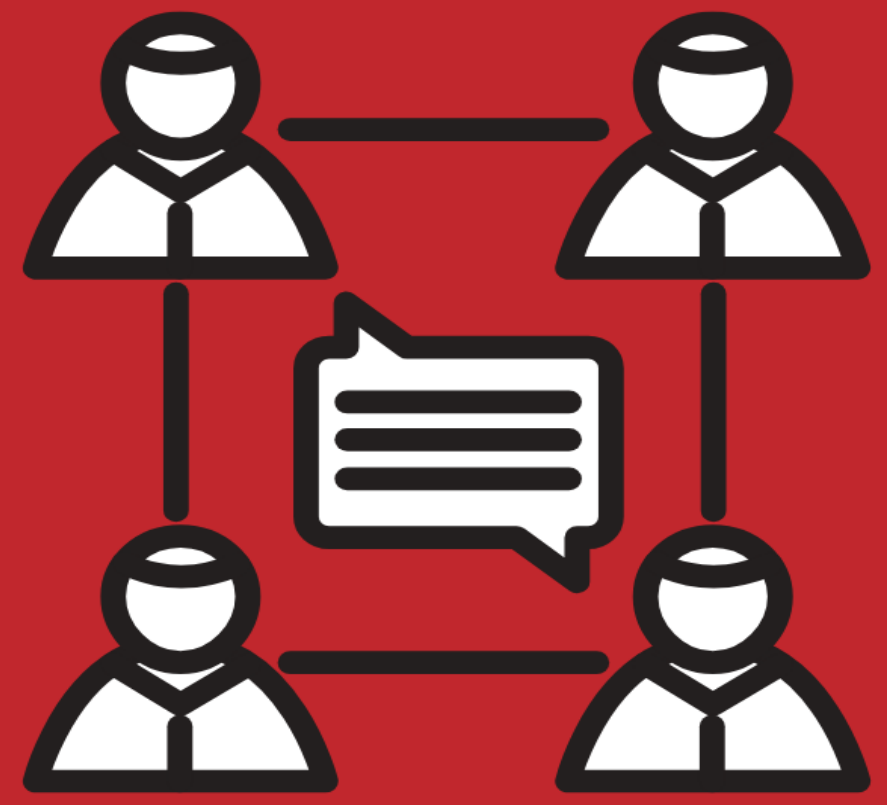

Kesimpulan dan Rekomendasi

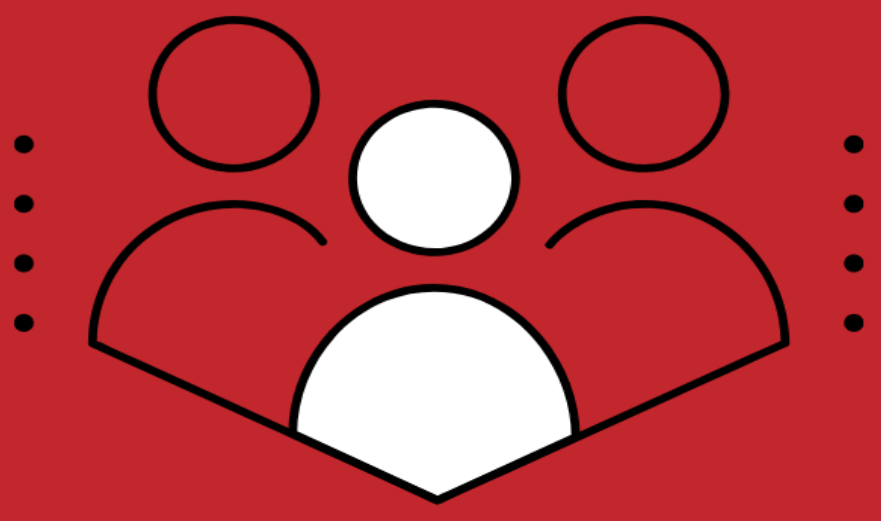




\section{Kesimpulan dan Rekomendasi}

Berdasarkan kajian yang telah dilakukan, dapat diambil kesimpulan sebagai berikut:

1. Pengendalian HIV di Indonesia memerlukan peran komunitas dalam penyelenggaraan pelayanan kesehatan terkait HIV pada tingkat integrasi penuh dan kolaborasi.

2. Meskipun dokumen kebijakan yang tersedia telah cukup memberi ruang pada integrasi peran komunitas dalam penyediaan pelayanan, berbagai hambatan hukum dan sistem pelayanan masih menjadi hambatan dan tantangan efektifitas layanan oleh komunitas terutama akibat masih adanya disharmonisasi dokumen kebijakan dan stigma serta diskriminasi di berbagai level layanan.

3. Terdapat 10 kelompok kegiatan yang diperankan oleh komunitas dalam program pengendalian HIV yang disepakati oleh pakar dapat diintegrasikan secara penuh ke dalam sistem pelayanan kesehatan terkait HIV. Kegiatan tersebut adalah:

a. Pelatihan kader penjangkau direkomendasikan untuk diupayakan dalam jangka pendek

b. Penjangkauan lapangan direkomendasikan untuk diupayakan dalam jangka pendek

c. Penjangkauan digital direkomendasikan untuk diupayakan dalam jangka panjang

d. Tes HIV mobil direkomendasikan untuk diupayakan dalam jangka pendek

e. Skrining HIV berbasis komunitas direkomendasikan untuk diupayakan dalam jangka panjang

f. Skrining HIV mandiri berbasis komunitas direkomendasikan untuk diupayakan dalam jangka panjang

g. Notifikasi pasangan direkomendasikan untuk diupayakan dalam jangka pendek

h. KDS direkomendasikan untuk diupayakan dalam jangka pendek

i. Layanan pendampingan pasien direkomendasikan untuk diupayakan dalam jangka pendek

j. Layanan pengawas minum obat direkomendasikan untuk diupayakan dalam jangka panjang

4. Terdapat kelompok kegiatan yang diperankan oleh komunitas dalam program pengendalian HIV yang disepakati oleh pakar dapat dikolaborasikan ke dalam sistem pelayanan kesehatan terkait HIV. Kegiatan tersebut adalah:

a. Sosialisasi skrining HIV mandiri berbasis komunitas direkomendasikan untuk diupayakan dalam jangka pendek

b. Dukungan komunitas kultural/religius direkomendasikan untuk diupayakan dalam jangka panjang

c. Mobilisasi komunitas direkomendasikan untuk diupayakan dalam jangka pendek

d. Koordinasi kebijakan dengan pemangku kepentingan direkomendasikan untuk diupayakan dalam jangka pendek 
e. Kontribusi komunitas dalam protokol riset direkomendasikan untuk diupayakan dalam jangka panjang

5. Kebijakan operasional yang dibutuhkan untuk mewujudkan model pemosisian komunitas dalam sistem pelayanan kesehatan terkait HIV adalah:

a. Pendefinisian

b. Penuangan perencanaan dan road map tentang peralihan pendanaan biaya program pengendalian HIV yang memosisikan komunitas di dalamnya dari donor ke pendanaan oleh pemerintah pusat dan daerah secara bertahap oleh pemerintah yang diundangkan dalam lembaran negara dan disosialikasikan secara efektif kepada tiap pemangku kepentingan di Indonesia

c. Penyusunan regulasi yang secara spesifik mengatur peran, kapasitas, kompetensi, pemetaan, pengawasan, termasuk hak, dan kewajiban komunitas yang terlibat dalam komposisi pelayanan kesehatan terkait pencegahan dan PDP HIV, termasuk di dalamnya prosedur operasional yang menjamin sinergisitas dan harmonisasi kerja komunitas dengan fasilitas layanan kesehatan yang sudah ada

d. Pengembangan sistem pelaporan periodik kegiatan komunitas terkait upaya pengendalian HIV yang terintegrasi dalam SIHA dalam rangka integrasi data, pengukuran, dan pelaporan kinerja komunitas secara nasional ke dalam sistem informasi dan manajemen data serta pengambilan keputusan strategis terkait program pengendalian HIV di Indonesia

e. Terkait desentralisasi diharapkan pemerintah pusat dapat menerbitkan pedoman guna membentuk kesamaan persepsi dan penegakan prinsip non-diskriminasi dan nonstigmatisasai dengan pemerintah daerah dalam upaya PDP HIV untuk pencapaian target yang diinginkan 

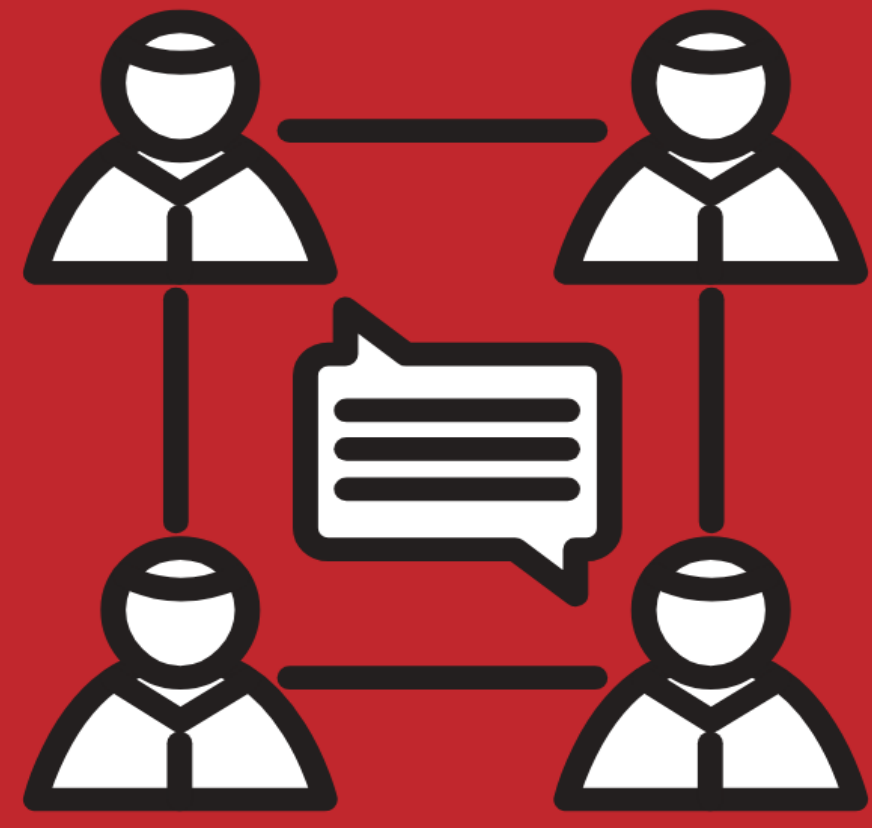

Lampiran-Lampiran

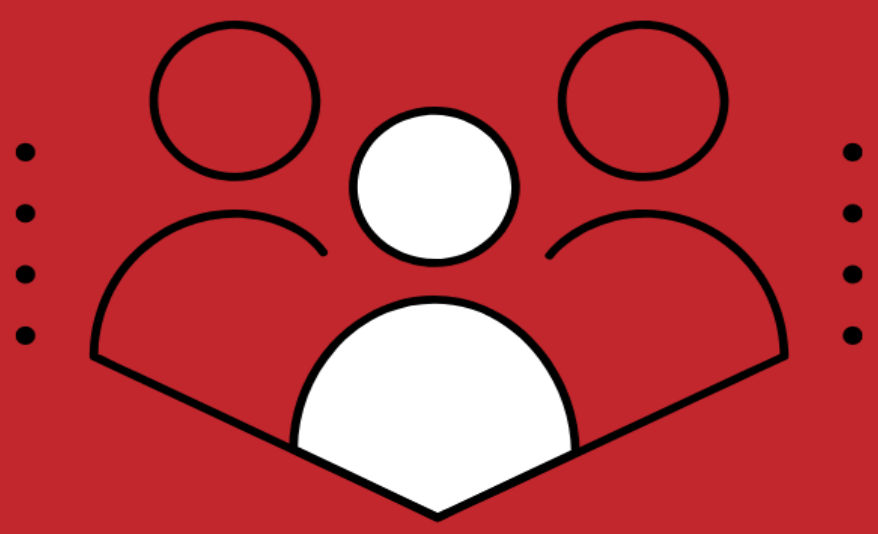




\section{Lampiran}

\subsection{Daftar Artikel Yang Digunakan Dalam Kaji Literatur No Artikel \\ Project}

Negara

1 Solomon et al., 2015

Project Muse

Canada

2 Day et al., 2020

$3 \quad$ K.Scott et al., 2013

$\mathrm{CAB}$ and Crowdsourcing approach

USA

Community Mobilization and ART Adherence

Zimbabwe

$4 \quad$ Kemp et al., 2016

$5 \quad$ Chaang et al., 2021

Community based Support and Education Intervention

South Africa

Health Scout

Uganda

6 Kuo et al., 2019

7 Aantjes et al., 2016

mHealth Intervention

Washington DC

$\mathrm{CHBC}$ for HIV

Zambia

Proyecto Orgullo

Peru

She is Like a Sister to Me

USA

Wan Kanyakla (We are Together)

Kenya

Community Mobilization (CM)

South Africa

Hybrid Design

Malawi

Swab2know

Belgium

Barbershop Talk with brothers (BTWB)

USA

$\mathrm{CBO}$ at Epicentro Salud

Peru

$\mathrm{M}-\mathrm{HIT}$

South Africa

Integrated Community-Base Health System Strengthening (ICBHSS)

18 Wilson et al., 2014

BTWB Project

Togo

Street-based HIV Testing

USA

19 Young et al., 2019

Crowdsourcing on HIV Clinic Trial

USA

20 Day et al., 2020

COPR Model

USA

Engaging FSW to HIV Program

USA

21 DeShields et al., 2020

Zimbabwe

Community Engagement among MSM

Taiwan

CBPR in developing HIV Dissability Questionnaire

Canada

Community Engagement of HIV Testing

China

Role of CHW on PMTCT

Tanzania

Community Mobilization

Zambia

Scale-up HIV Testing

Zimbabwe

Investigators Program

Canada

Community -Supported models of HIV Treatment

Sub Saharan Africa

2BeatHIV

USA

Crowdsourcing on HIV Cure

China

Role of CHW on HIV Hot Spot

USA

NIMH Projects

Africa

\section{TWEET Interventions}

USA 


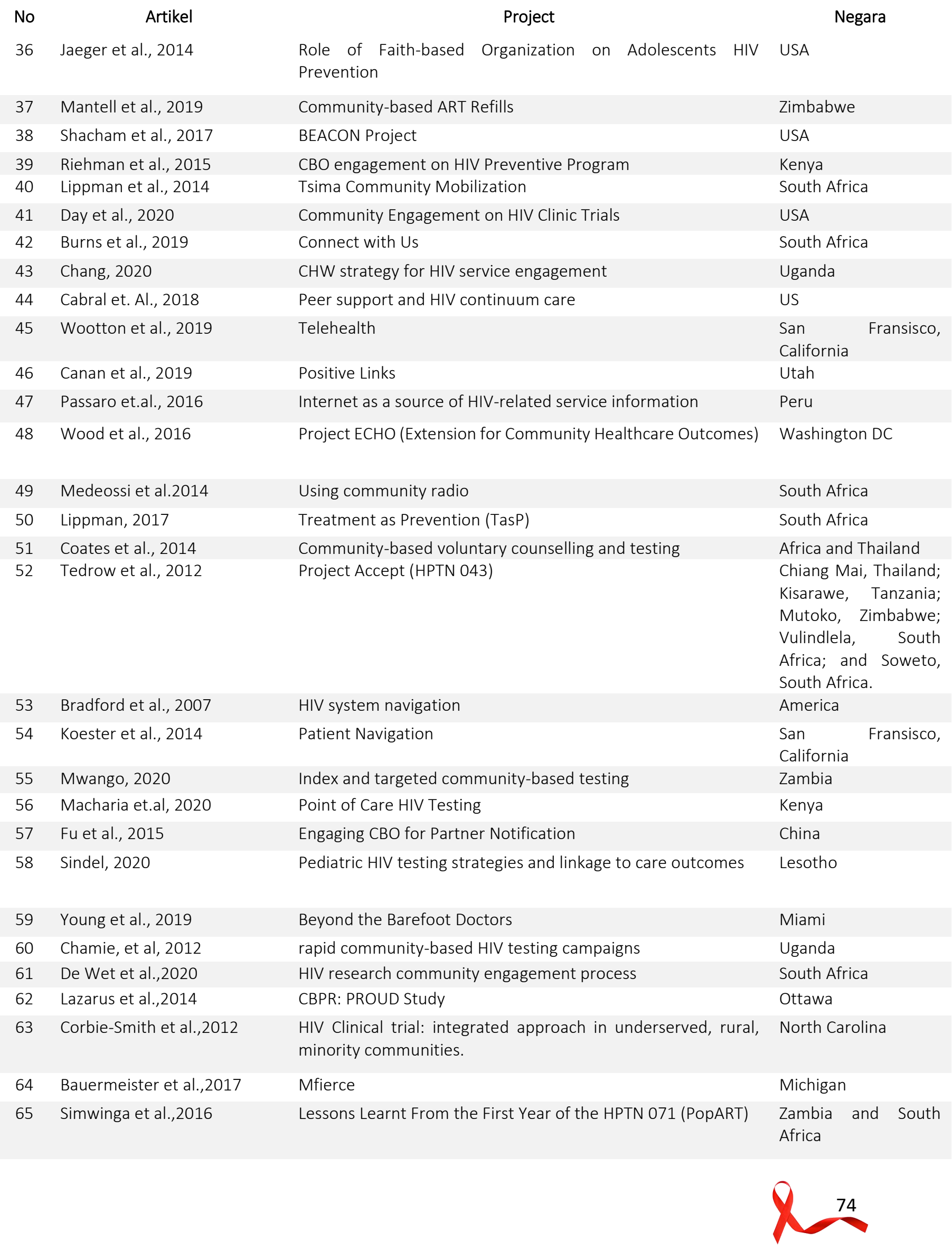




\begin{tabular}{|c|c|c|c|}
\hline No & Artikel & Project & Negara \\
\hline 66 & Caine et al.,2016 & Community-based Nurse Mentorship Intervention in HIV Care. & Canada \\
\hline 67 & Mathews et al.,2017 & Crowdsourcing contest & North Carolina \\
\hline 68 & Cordova et al.,2015 & CBPR involve youth leadership council for developing Mhealth & Michigan \\
\hline 69 & Beng et al.,2011 & Memorias & Cuba \\
\hline 70 & Hickey et al.,2015 & CBHP delivered by ward-based outreach teams (WBOTs) & Kenya \\
\hline 71 & Kamuzora et al.,2013 & REACT Project & Tanzania \\
\hline 72 & MacPhaill et al.,2019 & Community Action Teams & South Africa \\
\hline 73 & Corbie-Smith et al.,2010 & Project GRACE & North Carolina \\
\hline 74 & Sturmberg et al., 2016 & People-centred health service & Kenya \\
\hline 75 & Gosselin, et al.,2019 & Makasi Intervention & Sub Saharan Africa \\
\hline 76 & Shamu et al.,2018 & Linkage to Care of HIV Positive Clients & South Africa \\
\hline 77 & Kuhlman et al., 2014 & Avahan Project & India \\
\hline 78 & $\begin{array}{l}\text { Sandoval and Carlos F } \\
\text { Cáceres, } 2013\end{array}$ & Evaluation Study & Peru \\
\hline 79 & Almeida-Brasil et al.,2018 & Community mobilization in HIV treatment management & Brazil \\
\hline 80 & Laughlin et al.,2012 & Treatment Partners Intervention & Africa \\
\hline
\end{tabular}

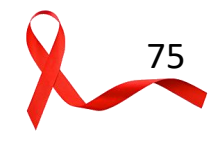




\subsection{Daftar Peraturan Perundangan Terkait Pencegahan HIV}

1. Undang-undang Nomor 36 Tahun 2009 tentang Kesehatan.

2. Peraturan Presiden RI Nomor 72 Tahun 2012 tentang Sistem Kesehatan Nasional

3. Peraturan Menteri Kesehatan Nomor 8 Tahun 2019 tentang Pemberdayaan Masyarakat Bidang Kesehatan

4. Peraturan Menteri Kesehatan RI Nomor 21 Tahun 2013 tentang Penanggulangan HIV dan AIDS.

5. Peraturan Menteri Kesehatan Nomor 51 tahun 2013 tentang Pedoman Pencegahan Penularan HIV dari Ibu ke Anak

6. Peraturan Menteri Kesehatan Nomor 59 tahun 2013 tentang Penyelenggaraan Pemeriksaan Laboratorium untuk Ibu Hamil, Bersalin dan Nifas.

7. Peraturan Menteri Kesehatan Nomor 74 tahun 2014 tentang Pedoman Pelaksanaan Konseling dan Tes HIV

8. Peraturan Menteri Kesehatan Republik Indonesia Nomor 52 Tahun 2013 Tentang Eliminasi Penularan Human Immunodeficiency Virus, Sifilis, Dan Hepatitis B Dari Ibu Ke Anak

9. Keputusan Menteri Kesehatan RI Nomor 1278/MENKES/SK/XII/2009 tentang Pedoman Pelaksanaan Kolaborasi Pengendalian Penyakit TB dan HIV.

10. Kesepakatan Bersama Menkes, Mendagri, Mendikbud, Menag dan Mensos RI tentang Peningkatan Pengetahuan Komprehensif HIV dan AIDS pada Penduduk Usia 15 sampai dengan 24 Tahun

11. Surat Edaran Menteri Kesehatan RI Nomor GK/MENKES/001/I/2013 tentang Layanan Pencegahan Penularan Human Immunodeficiency Virus (HIV) Dari Ibu ke Anak (PPIA)

12. Surat Edaran Menteri Kesehatan RI Nomor 129 Tahun 2013 tentang Pelaksanaan Pengendalian HIV DAN AIDS dan Infeksi Menular Seksual (IMS).

13. Surat Edaran Menteri Kesehatan RI Nomor HK.02.01/MENKES/37/2017 tentang Pelaksanaan Eliminasi Penularan HIV, Sifilis dan Hepatitis B dari Ibu ke Anak di Indonesia

14. Surat Edaran Direktorat Jenderal Pengendalian Penyakit dan Penyehatan Lingkungan Nomor HK.02.03/D/III.2/823/2013 tentang Alokasi Pembiayaan Logistik Program Pengendalian HIV DAN AIDS dan IMS.

15. Surat Edaran Dirjen Direktorat Jenderal Pelayanan Kesehatan HK.02.02/II/1739/2018 tentang Dukungan Eliminasi Penularan HIV

16. Surat Edaran Dirjen Direktorat Jenderal Pencegahan dan Pengendalian Penyakit Nomor PR.01.05/I/1822/2019 tentang Akselerasi ART

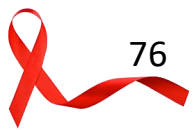




\subsection{Daftar Peraturan Perundangan terkait Upaya Perawatan, Dukungan, dan Pengobatan HIV}

1. Undang-undang Nomor 36 Tahun 2009 tentang Kesehatan.

2. Peraturan Pemerintah Nomor 2 Tahun 2018 Tentang Peraturan Pemerintah Republik Indonesia tentang Standar Pelayanan Minimal

3. Peraturan Menteri Kesehatan RI Nomor 21 Tahun 2013 tentang Penanggulangan HIV dan AIDS.

4. Peraturan Menteri Kesehatan Republik Indonesia Nomor 52 Tahun 2013 Tentang Eliminasi Penularan Human Immunodeficiency Virus, Sifilis, Dan Hepatitis B Dari Ibu Ke Anak

5. Peraturan Menteri Kesehatan Nomor 8 Tahun 2019 tentang Pemberdayaan Masyarakat Bidang Kesehatan

6. Peraturan Menteri Kesehatan RI Nomor 46 tahun 2012 tentang Petunjuk Teknis Pelaksanaan Rehabilitasi Medis bagi Pecandu, Penyalahguna, dan Korban Penyalahgunaan Narkotika yang dalam Proses atau yang telah Diputus oleh Pengadilan.

7. Peraturan Menteri Kesehatan Nomor 51 tahun 2013 tentang Pedoman Pencegahan Penularan HIV dari lbu ke Anak

8. Peraturan Menteri Kesehatan Nomor 57 tahun 2013 tentang Pedoman Penyelenggaraan Program Terapi Rumatan Metadon.

9. Peraturan Menteri Kesehatan Nomor 59 tahun 2013 tentang Penyelenggaraan Pemeriksaan Laboratorium untuk Ibu Hamil, Bersalin dan Nifas.

10. Peraturan Menteri Kesehatan Nomor 74 tahun 2014 tentang Pedoman Pelaksanaan Konseling dan Tes HIV

11. Keputusan Menteri Kesehatan RI Nomor 1190/MENKES/SK/X/2004 tentang Pemberian Gratis Obat Anti Tuberkulosis (OAT) dan Obat Anti Retro Viral (ARV) untuk HIV/AIDS.

12. Keputusan Menteri Kesehatan RI Nomor 1278/MENKES/SK /XII/2009 tentang Pedoman Pelaksanaan Kolaborasi Pengendalian Penyakit TB dan HIV.

13. Keputusan Menteri Kesehatan RI Nomor 451/MENKES/SK/XII/2012 tentang Rumah Sakit Rujukan bagi Orang Dengan HIV dan AIDS.

14. Peraturan Menteri Kesehatan Nomor 4 Tahun 2019 tentang Standar Teknis Pemenuhan Mutu Pelayanan Dasar Pada Standar Pelayanan Minimal Bidang Kesehatan.

15. Peraturan Menteri Dalam Negeri Republik Indonesia Nomor 100 Tahun 2018 Tentang Penerapan Standar Pelayanan Minimal

16. Keputusan Menteri Kesehatan RI Nomor HK.01.07/Menkes /90/2019. Tentang Pedoman Nasional Pelayanan Kedokteran Tata Laksana HIV

17. Keputusan Menteri Kesehatan No.HK.02.02-MENKES-514 tahun 2015 tentang Panduan Praktik Klinis Dokter Di Fasilitas Pelayanan Kesehatan Tingkat Pertama

18. Surat Edaran Menteri Kesehatan RI Nomor GK/MENKES/001/I/2013 tentang Layanan Pencegahan Penularan Human Immunodeficiency Virus (HIV) Dari Ibu ke Anak (PPIA)

19. Surat Edaran Menteri Kesehatan RI Nomor HK.02.01/MENKES /37/2017 tentang Pelaksanaan Eliminasi Penularan HIV, Sifilis dan Hepatitis B dari Ibu ke Anak di Indonesia

20. Surat Edaran Dirjen Direktorat Jenderal Pencegahan dan Pengendalian Penyakit Nomor PR.01.05/I/1822/2019 tentang Akselerasi ART

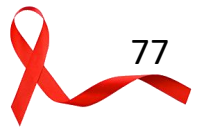


21. Surat Edaran Direktorat Jenderal Pengendalian Penyakit dan Penyehatan Lingkungan Nomor HK.02.03/D/ III.2/823/2013 tentang Alokasi Pembiayaan Logistik Program Pengendalian HIV DAN AIDS dan IMS.

22. Surat Edaran Direktur Jenderal BUK Nomor HK.03.03/III/0992/ 2014 Tentang Penyelenggaraan Pelayanan Orang dengan HIV-AIDS di Rumah Sakit

23. Surat Edaran Direkur Jenderal P2P No.HK.02.02/I/1564/2018 tentang Penatalaksanaan Orang dengan HIV AIDS (ODHA) untuk Eliminasi HIV AIDS tahun 2030 


\subsection{Formulir Pengumpulan Data Survei Delphi}

\begin{tabular}{|c|c|c|c|c|c|c|c|c|}
\hline \multirow[t]{2}{*}{$\begin{array}{l}\text { Fungsi } \\
\text { Layanan } \\
\text { Kesehatan }\end{array}$} & \multirow[t]{2}{*}{$\begin{array}{l}\text { Kegiatan } \\
\text { Keterlibatan } \\
\text { Komunitas }\end{array}$} & \multirow[t]{2}{*}{$\begin{array}{l}\text { Tingkat } \\
\text { Integrasi }\end{array}$} & \multirow[t]{2}{*}{ Kegiatan Integrasi } & \multicolumn{2}{|c|}{ Peran Komponen } & \multirow[t]{2}{*}{$\begin{array}{l}\text { Model penempatan } \\
\text { komunitas ini sudah } \\
\text { sesuai dengan best } \\
\text { practice berbasis } \\
\text { bukti }\end{array}$} & \multirow[t]{2}{*}{$\begin{array}{l}\text { Model penempatan } \\
\text { komunitas ini dapat } \\
\text { diterapkan dengan } \\
\text { kondisi di lapangan }\end{array}$} & \multirow[t]{2}{*}{$\begin{array}{l}\text { Catatan } \\
\text { Kritik/Saran }\end{array}$} \\
\hline & & & & Layanan Kesehatan & Komunitas & & & \\
\hline \multirow[t]{4}{*}{$\begin{array}{l}\text { Pencegahan } \\
\text {; layanan } \\
\text { perubahan } \\
\text { perilaku }\end{array}$} & $\begin{array}{l}\text { Pelatihan kader } \\
\text { penjangkau }\end{array}$ & Integrasi & $\begin{array}{l}\text { - Pemetaan kebutuhan } \\
\text { penjangkau bersama } \\
\text { - Penyusunan modul } \\
\text { pelatihan bersama } \\
\text { - Evaluasi program } \\
\text { bersama }\end{array}$ & $\begin{array}{l}\text { - Menyiapkan materi } \\
\text { pelatihan kader } \\
\text { penjangkau } \\
\text { - Sebagai tenaga ahli } \\
\text { dalam pelatihan kader } \\
\text { penjangkau }\end{array}$ & $\begin{array}{l}\text { - Perekrutan kader } \\
\text { penjangkau }\end{array}$ & $\begin{array}{l}\text { - Sangat tidak setuju } \\
\text { - Tidak setuju } \\
\text { - Netral } \\
\text { - Setuju } \\
\text { - Sangat setuju }\end{array}$ & $\begin{array}{l}\text { - Sangat tidak setuju } \\
\text { - Tidak setuju } \\
\text { - Netral } \\
\text { - Setuju } \\
\text { - Sangat setuju }\end{array}$ & \\
\hline & $\begin{array}{l}\text { Penjangkauan } \\
\text { lapangan }\end{array}$ & Koordinasi & $\begin{array}{l}\text { - Penghubungan saluran } \\
\text { komunikasi dan } \\
\text { perujukan bagi } \\
\text { populasi kunci yang } \\
\text { terjangkau kader }\end{array}$ & $\begin{array}{l}\text { - Membuka saluran } \\
\text { perujukan untuk } \\
\text { populasi kunci yang } \\
\text { terjangkau }\end{array}$ & $\begin{array}{l}\text { - Memetakan sasaran } \\
\text { penjangkauan untuk } \\
\text { luaran maksimal } \\
\text { - Melaksanakan } \\
\text { penjangkauan }\end{array}$ & $\begin{array}{l}\text { - Sangat tidak setuju } \\
\text { - Tidak setuju } \\
\text { - Netral } \\
\text { - Setuju } \\
\text { - Sangat setuju }\end{array}$ & $\begin{array}{l}\text { - Sangat tidak setuju } \\
\text { - Tidak setuju } \\
\text { - Netral } \\
\text { - Setuju } \\
\text { - Sangat setuju }\end{array}$ & \\
\hline & $\begin{array}{l}\text { Penjangkauan } \\
\text { digital }\end{array}$ & Koordinasi & $\begin{array}{l}\text { - Membuka saluran } \\
\text { rujukan bagi anggota } \\
\text { populasi kunci yang } \\
\text { terjangkau }\end{array}$ & $\begin{array}{l}\text { - Menerima rujukan } \\
\text { kasus berisiko tinggi } \\
\text { yang terjangkau }\end{array}$ & $\begin{array}{l}\text { - Melaksanakan } \\
\text { penjangkauan } \\
\text { - Merujuk kasus yang } \\
\text { teridentifikasi berisiko } \\
\text { tinggi }\end{array}$ & $\begin{array}{l}\text { - Sangat tidak setuju } \\
\text { - Tidak setuju } \\
\text { - Netral } \\
\text { - Setuju } \\
\text { - Sangat setuju }\end{array}$ & $\begin{array}{l}\text { - Sangat tidak setuju } \\
\text { - Tidak setuju } \\
\text { - Netral } \\
\text { - Setuju } \\
\text { - Sangat setuju }\end{array}$ & \\
\hline & $\begin{array}{l}\text { Mobilisasi } \\
\text { komunitas }\end{array}$ & Kolaborasi & $\begin{array}{l}\text { - Perencanaan kegiatan } \\
\text { bersama } \\
\text { - Identifikasi topik dan } \\
\text { penyusunan modul } \\
\text { bersama } \\
\text { - Evaluasi bersama }\end{array}$ & $\begin{array}{l}\text { - Menyusun modul } \\
\text { pelatihan dan edukasi } \\
\text { sesuai identifikasi topik } \\
\text { dari komunitas } \\
\text { - Memberi pelatihan } \\
\text { sebagai tenaga ahli }\end{array}$ & $\begin{array}{l}\text { - Mengidentifikasi topik } \\
\text { edukasi yang urgen bagi } \\
\text { komunitas } \\
\text { - Mobilisasi komunitas } \\
\text { untuk mendapat edukasi }\end{array}$ & $\begin{array}{l}\text { - Sangat tidak setuju } \\
\text { - Tidak setuju } \\
\text { - Netral } \\
\text { - Setuju } \\
\text { - Sangat setuju }\end{array}$ & $\begin{array}{l}\text { - Sangat tidak setuju } \\
\text { - Tidak setuju } \\
\text { - Netral } \\
\text { - Setuju } \\
\text { - Sangat setuju }\end{array}$ & \\
\hline $\begin{array}{l}\text { Diagnosis } \\
\text { tepat dan } \\
\text { cepat } \\
\text { termasuk }\end{array}$ & Mobile tes HIV & Integrasi & $\begin{array}{l}\text { - Perencanaan kegiatan } \\
\text { bersama }\end{array}$ & $\begin{array}{l}\text { - Terlibat dalam } \\
\text { perencanaan dan } \\
\text { penyusunan standar }\end{array}$ & $\begin{array}{l}\text { - Terlibat dalam } \\
\text { perencanaan dan } \\
\text { penyusunan standar }\end{array}$ & $\begin{array}{l}\text { - Sangat tidak setuju } \\
\text { - Tidak setuju } \\
\text { - Netral } \\
\text { - Setuju }\end{array}$ & $\begin{array}{l}\text { - Sangat tidak setuju } \\
\text { - Tidak setuju } \\
\text { - Netral } \\
\text { - Setuju }\end{array}$ & \\
\hline
\end{tabular}




\begin{tabular}{|c|c|c|c|c|c|c|c|c|}
\hline \multirow{2}{*}{$\begin{array}{l}\text { Fungsi } \\
\text { Layanan } \\
\text { Kesehatan }\end{array}$} & \multirow{2}{*}{$\begin{array}{l}\text { Kegiatan } \\
\text { Keterlibatan } \\
\text { Komunitas }\end{array}$} & \multirow{2}{*}{$\begin{array}{l}\text { Tingkat } \\
\text { Integrasi }\end{array}$} & \multirow{2}{*}{ Kegiatan Integrasi } & \multicolumn{2}{|c|}{ Peran Komponen } & \multirow{2}{*}{$\begin{array}{l}\text { Model penempatan } \\
\text { komunitas ini sudah } \\
\text { sesuai dengan best } \\
\text { practice berbasis } \\
\text { bukti }\end{array}$} & \multirow{2}{*}{$\begin{array}{l}\text { Model penempatan } \\
\text { komunitas ini dapat } \\
\text { diterapkan dengan } \\
\text { kondisi di lapangan }\end{array}$} & \multirow{2}{*}{$\begin{array}{l}\text { Catatan } \\
\text { Kritik/Saran }\end{array}$} \\
\hline & & & & Layanan Kesehatan & Komunitas & & & \\
\hline \multirow[t]{4}{*}{$\begin{array}{l}\text { skrining } \\
\text { berbasis } \\
\text { komunitas } \\
\text { dan metode } \\
\text { lainnya }\end{array}$} & & & $\begin{array}{l}\text { - Penyusunan standar } \\
\text { operasi tes HIV } \\
\text { bersama } \\
\text { - Pengelolaan sumber } \\
\text { daya bersama } \\
\text { - Evaluasi program } \\
\text { bersama } \\
\text { - Pemetaan titik panas } \\
\text { untuk tes HIV bersama } \\
\text { - Membuka jalur } \\
\text { pelayanan bagi } \\
\text { populasi kunci yang } \\
\text { terdiagnosis HIV }\end{array}$ & $\begin{array}{l}\text { operasi tes HIV yang } \\
\text { tepat secara klinis } \\
\text { - Penyediaan SDM } \\
\text { tenaga kesehatan } \\
\text { - Penyediaan HIV test kit } \\
\text { - Melakukan konfirmasi } \\
\text { diagnosis HIV }\end{array}$ & $\begin{array}{l}\text { operasi tes HIV yang } \\
\text { diterima komunitas } \\
\text { - Pemetaan titik panas } \\
\text { untuk lokasi tes mobile } \\
\text { - Mobilisasi komunitas di } \\
\text { titik panas untuk } \\
\text { menerima tes HIV }\end{array}$ & - Sangat setuju & - Sangat setuju & \\
\hline & $\begin{array}{l}\text { Tes HIV berbasis } \\
\text { komunitas }\end{array}$ & Integrasi & $\begin{array}{l}\text { - Perencanaan kegiatan } \\
\text { bersama } \\
\text { - Penyusunan standar } \\
\text { operasi tes HIV } \\
\text { bersama } \\
\text { - Pengelolaan sumber } \\
\text { daya bersama } \\
\text { - Evaluasi program } \\
\text { bersama } \\
\text { - Membuka jalur } \\
\text { pelayanan bagi } \\
\text { populasi kunci yang } \\
\text { terdiagnosis HIV }\end{array}$ & $\begin{array}{l}\text { - Terlibat dalam } \\
\text { perencanaan dan } \\
\text { penyusunan standar } \\
\text { operasi tes HIV yang } \\
\text { tepat secara klinis } \\
\text { - Penyediaan SDM } \\
\text { tenaga kesehatan } \\
\text { - Penyediaan HIV test kit } \\
\text { - Melakukan konfirmasi } \\
\text { diagnosis HIV }\end{array}$ & $\begin{array}{l}\text { - Terlibat dalam } \\
\text { perencanaan dan } \\
\text { penyusunan operasi } \\
\text { standar tes HIV yang bisa } \\
\text { diterima komunitas } \\
\text { - Pemetaan kebutuhan } \\
\text { sumber daya } \\
\text { - Mobilisasi komunitas } \\
\text { untuk menerima tes HIV }\end{array}$ & $\begin{array}{l}\text { - Sangat tidak setuju } \\
\text { - Tidak setuju } \\
\text { - Netral } \\
\text { - Setuju } \\
\text { - Sangat setuju }\end{array}$ & $\begin{array}{l}\text { - Sangat tidak setuju } \\
\text { - Tidak setuju } \\
\text { - Netral } \\
\text { - Setuju } \\
\text { - Sangat setuju }\end{array}$ & \\
\hline & $\begin{array}{l}\text { Sosialisasi tes } \\
\text { HIV mandiri } \\
\text { berbasis } \\
\text { komunitas }\end{array}$ & Kolaborasi & $\begin{array}{l}\text { - Perencanaan kegiatan } \\
\text { bersama }\end{array}$ & $\begin{array}{l}\text { - Menyusun modul } \\
\text { sosialisasi dan edukasi } \\
\text { bersama komunitas }\end{array}$ & $\begin{array}{l}\text { - Menyusun modul } \\
\text { sosialisasi dan edukasi } \\
\text { yang bisa diterima } \\
\text { komunitas }\end{array}$ & $\begin{array}{l}\text { - Sangat tidak setuju } \\
\text { - Tidak setuju } \\
\text { - Netral } \\
\text { - Setuju }\end{array}$ & $\begin{array}{l}\text { - Sangat tidak setuju } \\
\text { - Tidak setuju } \\
\text { - Netral } \\
\text { - Setuju }\end{array}$ & \\
\hline & & & & & & & & 80 \\
\hline
\end{tabular}




\begin{tabular}{|c|c|c|c|c|c|c|c|c|}
\hline \multirow{5}{*}{$\begin{array}{l}\text { Fungsi } \\
\text { Layanan } \\
\text { Kesehatan }\end{array}$} & \multirow{2}{*}{$\begin{array}{l}\text { Kegiatan } \\
\text { Keterlibatan } \\
\text { Komunitas }\end{array}$} & \multirow{2}{*}{$\begin{array}{l}\text { Tingkat } \\
\text { Integrasi }\end{array}$} & \multirow{2}{*}{ Kegiatan Integrasi } & \multicolumn{2}{|c|}{ Peran Komponen } & \multirow{2}{*}{$\begin{array}{l}\text { Model penempatan } \\
\text { komunitas ini sudah } \\
\text { sesuai dengan best } \\
\text { practice berbasis } \\
\text { bukti }\end{array}$} & \multirow{2}{*}{$\begin{array}{l}\text { Model penempatan } \\
\text { komunitas ini dapat } \\
\text { diterapkan dengan } \\
\text { kondisi di lapangan }\end{array}$} & \multirow{2}{*}{$\begin{array}{l}\text { Catatan } \\
\text { Kritik/Saran }\end{array}$} \\
\hline & & & & Layanan Kesehatan & Komunitas & & & \\
\hline & & & $\begin{array}{l}\text { - Penyusunan modul } \\
\text { sosialisasi dan edukasi } \\
\text { tes mandiri } \\
\text { - Evaluasi program } \\
\text { bersama }\end{array}$ & $\begin{array}{l}\text { - Menjadi tenaga ahli } \\
\text { dalam sosialisasi dan } \\
\text { edukasi tes mandiri } \\
\text { - Menyiapkan tanggapan } \\
\text { atas respon dan } \\
\text { persepsi komunitas } \\
\text { tentang tes HIV mandiri }\end{array}$ & $\begin{array}{l}\text { - Mobilisasi anggota } \\
\text { komunitas untuk } \\
\text { menghadiri sosialisasi } \\
\text { dan edukasi tentang tes } \\
\text { mandiri } \\
\text { - Mengevaluasi respon dan } \\
\text { persepsi komunitas } \\
\text { tentang tes HIV mandiri }\end{array}$ & - Sangat setuju & - Sangat setuju & \\
\hline & $\begin{array}{l}\text { Tes HIV mandiri } \\
\text { berbasis } \\
\text { komunitas }\end{array}$ & Integrasi & $\begin{array}{l}\text { - Perencanaan kegiatan } \\
\text { bersama } \\
\text { - Penyusunan standar } \\
\text { operasi untuk } \\
\text { diagnosis HIV dengan } \\
\text { tes mandiri bersama } \\
\text { - Pemetaan dan } \\
\text { pengelolaan sumber } \\
\text { daya bersama } \\
\text { - Membuka jalur } \\
\text { pelayanan bagi } \\
\text { populasi kunci yang } \\
\text { terdiagnosis HIV } \\
\text { - Evaluasi program } \\
\text { bersama }\end{array}$ & $\begin{array}{l}\text { - Terlibat dalam } \\
\text { perencanaan dan } \\
\text { penyusunan standar } \\
\text { operasi tes HIV mandiri } \\
\text { yang tepat secara klinis } \\
\text { - Penyediaan SDM } \\
\text { tenaga kesehatan } \\
\text { - Penyediaan HIV test kit } \\
\text { - Melakukan konfirmasi } \\
\text { diagnosis HIV }\end{array}$ & $\begin{array}{l}\text { - Terlibat dalam } \\
\text { perencanaan dan } \\
\text { penyusunan operasi } \\
\text { standar tes HIV mandiri } \\
\text { yang bisa diterima } \\
\text { komunitas } \\
\text { - Menyalurkan kit tes } \\
\text { mandiri pada anggota } \\
\text { komunitas dan } \\
\text { melakukan follow up } \\
\text { untuk hasilnya } \\
\text { - Merujuk anggota } \\
\text { komunitas yang } \\
\text { melaporkan hasil positif }\end{array}$ & $\begin{array}{l}\text { - Sangat tidak setuju } \\
\text { - Tidak setuju } \\
\text { - Netral } \\
\text { - Setuju } \\
\text { - Sangat setuju }\end{array}$ & $\begin{array}{l}\text { - Sangat tidak setuju } \\
\text { - Tidak setuju } \\
\text { - Netral } \\
\text { - Setuju } \\
\text { - Sangat setuju }\end{array}$ & \\
\hline & $\begin{array}{l}\text { Notifikasi } \\
\text { pasangan }\end{array}$ & Integrasi & $\begin{array}{l}\text { - Penyusunan standar } \\
\text { operasi notifikasi } \\
\text { pasangan bersama } \\
\text { - Pengembangan } \\
\text { database dan evaluasi } \\
\text { program bersama }\end{array}$ & $\begin{array}{l}\text { - Menyusun standar } \\
\text { operasi bersama } \\
\text { komunitas yang efektif } \\
\text { berdasarkan bukti } \\
\text { dalam literatur } \\
\text { - Merekrut dan melatih } \\
\text { tenaga kesehatan }\end{array}$ & $\begin{array}{l}\text { - Menyusun standar } \\
\text { operasi bersama layanan } \\
\text { yang dapat diterima } \\
\text { anggota komunitas } \\
\text { - Merekrut dan melatih } \\
\text { penjangkau dan } \\
\text { pendamping sebaya }\end{array}$ & $\begin{array}{l}\text { - Sangat tidak setuju } \\
\text { - Tidak setuju } \\
\text { - Netral } \\
\text { - Setuju } \\
\text { - Sangat setuju }\end{array}$ & $\begin{array}{l}\text { - Sangat tidak setuju } \\
\text { - Tidak setuju } \\
\text { - Netral } \\
\text { - Setuju } \\
\text { - Sangat setuju }\end{array}$ & \\
\hline
\end{tabular}




\begin{tabular}{|c|c|c|c|c|c|c|c|c|}
\hline \multirow{3}{*}{$\begin{array}{l}\text { Fungsi } \\
\text { Layanan } \\
\text { Kesehatan }\end{array}$} & \multirow{3}{*}{$\begin{array}{l}\text { Kegiatan } \\
\text { Keterlibatan } \\
\text { Komunitas }\end{array}$} & \multirow{3}{*}{$\begin{array}{l}\text { Tingkat } \\
\text { Integrasi }\end{array}$} & \multirow{3}{*}{ Kegiatan Integrasi } & \multicolumn{2}{|c|}{ Peran Komponen } & \multirow{2}{*}{$\begin{array}{l}\text { Model penempatan } \\
\text { komunitas ini sudah } \\
\text { sesuai dengan best } \\
\text { practice berbasis } \\
\text { bukti }\end{array}$} & \multirow{2}{*}{$\begin{array}{l}\text { Model penempatan } \\
\text { komunitas ini dapat } \\
\text { diterapkan dengan } \\
\text { kondisi di lapangan }\end{array}$} & \multirow{3}{*}{$\begin{array}{l}\text { Catatan } \\
\text { Kritik/Saran }\end{array}$} \\
\hline & & & & Layanan Kesehatan & Komunitas & & & \\
\hline & & & & $\begin{array}{l}\text { untuk melakukan } \\
\text { konseling notifikasi } \\
\text { pasangan } \\
\text { - Mencatat dan } \\
\text { melaporkan luaran } \\
\text { - Evaluasi bersama } \\
\text { dengan komunitas }\end{array}$ & $\begin{array}{l}\text { untuk melakukan } \\
\text { notifikasi pasangan } \\
\text { - Mencatat dan } \\
\text { melaporkan luaran } \\
\text { - Evaluasi bersama dengan } \\
\text { layanan }\end{array}$ & & & \\
\hline \multirow{4}{*}{$\begin{array}{l}\text { Manajemen } \\
\text { medis dan } \\
\text { klinis } \\
\text { termasuk } \\
\text { layanan } \\
\text { dukungan } \\
\text { diagnostik } \\
\text { dan } \\
\text { dukungan } \\
\text { memulai } \\
\text { terapi }\end{array}$} & $\begin{array}{l}\text { Kelompok } \\
\text { dukungan } \\
\text { sebaya }\end{array}$ & Koordinasi & $\begin{array}{l}\text { - Jaluran saling rujuk } \\
\text { pasien untuk terapi } \\
\text { ARV dan dukungan } \\
\text { komunitas }\end{array}$ & $\begin{array}{l}\text { - Pemberian terapi ARV } \\
\text { - Rujuk pasien yang } \\
\text { kesulitan memulai } \\
\text { terapi untuk menerima } \\
\text { dukungan komunitas }\end{array}$ & $\begin{array}{l}\text { - Memberi masukan } \\
\text { mengenai rencana terapi } \\
\text { yang dapat diterima } \\
\text { pasien } \\
\text { - Identifikasi alasan pasien } \\
\text { kesulitan memulai terapi }\end{array}$ & $\begin{array}{l}\text { - Sangat tidak setuju } \\
\text { - Tidak setuju } \\
\text { - Netral } \\
\text { - Setuju } \\
\text { - Sangat setuju }\end{array}$ & $\begin{array}{l}\text { - Sangat tidak setuju } \\
\text { - Tidak setuju } \\
\text { - Netral } \\
\text { - Setuju } \\
\text { - Sangat setuju }\end{array}$ & \\
\hline & $\begin{array}{l}\text { Layanan } \\
\text { pendampingan } \\
\text { pasien }\end{array}$ & Kolaborasi & $\begin{array}{l}\text { - Penyusunan standar } \\
\text { operasi layanan } \\
\text { kesehatan yang mudah } \\
\text { dimengerti pasien dan } \\
\text { komunitas } \\
\text { - Menyediakan jalur } \\
\text { komunikasi bagi } \\
\text { komunitas untuk } \\
\text { membantu pasien } \\
\text { menavigasi sistem } \\
\text { layanan kesehatan }\end{array}$ & $\begin{array}{l}\text { - Penyusunan standar } \\
\text { operasi layanan HIV } \\
\text { bersama komunitas } \\
\text { - Menyediakan saluran } \\
\text { komunikasi untuk } \\
\text { membantu pasien dan } \\
\text { pendamping komunitas }\end{array}$ & $\begin{array}{l}\text { - Penyusunan standar } \\
\text { operasi layanan HIV } \\
\text { bersama layanan } \\
\text { kesehatan } \\
\text { - Menyediakan } \\
\text { pendamping yang } \\
\text { membantu pasien } \\
\text { menavigasi sistem } \\
\text { layanan HIV }\end{array}$ & $\begin{array}{l}\text { - Sangat tidak setuju } \\
\text { - Tidak setuju } \\
\text { - Netral } \\
\text { - Setuju } \\
\text { - Sangat setuju }\end{array}$ & $\begin{array}{l}\text { - Sangat tidak setuju } \\
\text { - Tidak setuju } \\
\text { - Netral } \\
\text { - Setuju } \\
\text { - Sangat setuju }\end{array}$ & \\
\hline & $\begin{array}{l}\text { Pengawas } \\
\text { minum obat }\end{array}$ & Kolaboratif & $\begin{array}{l}\text { Penyusunan standar } \\
\text { operasi yang efektif } \\
\text { dan dapat diterima } \\
\text { komunitas }\end{array}$ & $\begin{array}{l}\text { - Menyusun standar } \\
\text { operasi yang efektif } \\
\text { sesuai bukti bersama } \\
\text { komunitas } \\
\text { - Melatih pengawas } \\
\text { minum obat }\end{array}$ & $\begin{array}{l}\text { - Menyusun standar } \\
\text { operasi yang dapat } \\
\text { diterima komunitas } \\
\text { bersama layanan } \\
\text { - Mensosialisasikan dan } \\
\text { merekrut pengawas }\end{array}$ & $\begin{array}{l}\text { - Sangat tidak setuju } \\
\text { - Tidak setuju } \\
\text { - Netral } \\
\text { - Setuju } \\
\text { - Sangat setuju }\end{array}$ & $\begin{array}{l}\text { - Sangat tidak setuju } \\
\text { - Tidak setuju } \\
\text { - Netral } \\
\text { - Setuju } \\
\text { - Sangat setuju }\end{array}$ & \\
\hline & & & & & & & & 82 \\
\hline
\end{tabular}




\begin{tabular}{|c|c|c|c|c|c|c|c|c|}
\hline \multirow{3}{*}{$\begin{array}{l}\text { Fungsi } \\
\text { Layanan } \\
\text { Kesehatan }\end{array}$} & \multirow{2}{*}{$\begin{array}{l}\text { Kegiatan } \\
\text { Keterlibatan } \\
\text { Komunitas }\end{array}$} & \multirow{2}{*}{$\begin{array}{l}\text { Tingkat } \\
\text { Integrasi }\end{array}$} & \multirow{2}{*}{ Kegiatan Integrasi } & \multicolumn{2}{|c|}{ Peran Komponen } & \multirow{2}{*}{$\begin{array}{l}\text { Model penempatan } \\
\text { komunitas ini sudah } \\
\text { sesuai dengan best } \\
\text { practice berbasis } \\
\text { bukti }\end{array}$} & \multirow{2}{*}{$\begin{array}{l}\text { Model penempatan } \\
\text { komunitas ini dapat } \\
\text { diterapkan dengan } \\
\text { kondisi di lapangan }\end{array}$} & \multirow{2}{*}{$\begin{array}{l}\text { Catatan } \\
\text { Kritik/Saran }\end{array}$} \\
\hline & & & & Layanan Kesehatan & Komunitas & & & \\
\hline & & & $\begin{array}{l}\text { - Perekrutan dan } \\
\text { pelatihan pengawas } \\
\text { minum obat } \\
\text { - Membuka jalur } \\
\text { komunikasi untuk } \\
\text { kasus-kasus kepatuhan } \\
\text { minum obat yang } \\
\text { rendah } \\
\text { - Evaluasi program } \\
\text { bersama }\end{array}$ & $\begin{array}{l}\text { - Menangani pasien yang } \\
\text { tidak taat minum obat } \\
\text { bersama komunitas }\end{array}$ & $\begin{array}{l}\text { minum obat dari ODHA di } \\
\text { komunitas } \\
\text { - Menangani pasien yang } \\
\text { tidak taat minum obat } \\
\text { bersama layanan }\end{array}$ & & & \\
\hline \multirow[t]{2}{*}{$\begin{array}{l}\text { Dukungan } \\
\text { psikososial } \\
\text { dalam } \\
\text { konteks } \\
\text { lokal/kultura } \\
\text { l/religius }\end{array}$} & $\begin{array}{l}\text { Kelompok } \\
\text { dukungan } \\
\text { sebaya }\end{array}$ & Kolaborasi & $\begin{array}{l}\text { - Saluran rujukan dari } \\
\text { layanan ke komunitas } \\
\text { untuk dukungan } \\
\text { psikososial } \\
\text { - Saluran rujukan dari } \\
\text { komunitas untuk } \\
\text { layanan kesehatan } \\
\text { mental } \\
\text { - Penyusunan bersama } \\
\text { standar operasi yang } \\
\text { inklusif }\end{array}$ & $\begin{array}{l}\text { - Menyusun standar } \\
\text { operasi pelayanan } \\
\text { inklusif bersama } \\
\text { komunitas } \\
\text { - Mengarahkan } \\
\text { pasien/populasi kunci } \\
\text { untuk ikut serta dalam } \\
\text { komunitas }\end{array}$ & $\begin{array}{l}\text { - Menyusun standar } \\
\text { operasi pelayanan } \\
\text { inklusif bersama layanan } \\
\text { kesehatan } \\
\text { - Memberikan ruang aman } \\
\text { dan sistem dukungan } \\
\text { (support system) sebagai } \\
\text { bentuk dukungan } \\
\text { psikososial bagi ODHA } \\
\text { dan populasi kunci } \\
\text { - Mengidentifikasi dan } \\
\text { merujuk anggota yang } \\
\text { perlu layanan kesehatan } \\
\text { mental profesional }\end{array}$ & $\begin{array}{l}\text { - Sangat tidak setuju } \\
\text { - Tidak setuju } \\
\text { - Netral } \\
\text { - Setuju } \\
\text { - Sangat setuju }\end{array}$ & $\begin{array}{l}\text { - Sangat tidak setuju } \\
\text { - Tidak setuju } \\
\text { - Netral } \\
\text { - Setuju } \\
\text { - Sangat setuju }\end{array}$ & \\
\hline & $\begin{array}{l}\text { Dukungan } \\
\text { komunitas } \\
\text { kultural/religiou } \\
\text { s }\end{array}$ & Kolaborasi & $\begin{array}{l}\text { - Saluran rujukan dari } \\
\text { layanan ke komunitas } \\
\text { untuk dukungan } \\
\text { psikososial } \\
\text { - Saluran rujukan dari } \\
\text { komunitas untuk }\end{array}$ & $\begin{array}{l}\text { - Menyusun standar } \\
\text { operasi pelayanan } \\
\text { sensitive identitas } \\
\text { budaya dan agama } \\
\text { - Mengarahkan } \\
\text { pasien/populasi kunci }\end{array}$ & $\begin{array}{l}\text { - Menyusun standar } \\
\text { operasi pelayanan } \\
\text { sensitive identitas } \\
\text { budaya/agama bersama } \\
\text { layanan kesehatan }\end{array}$ & $\begin{array}{l}\text { - Sangat tidak setuju } \\
\text { - Tidak setuju } \\
\text { - Netral } \\
\text { - Setuju } \\
\text { - Sangat setuju }\end{array}$ & $\begin{array}{l}\text { - Sangat tidak setuju } \\
\text { - Tidak setuju } \\
\text { - Netral } \\
\text { - Setuju } \\
\text { - Sangat setuju }\end{array}$ & \\
\hline
\end{tabular}




\begin{tabular}{|c|c|c|c|c|c|c|c|c|}
\hline \multirow[t]{2}{*}{$\begin{array}{l}\text { Fungsi } \\
\text { Layanan } \\
\text { Kesehatan }\end{array}$} & \multirow[t]{2}{*}{$\begin{array}{l}\text { Kegiatan } \\
\text { Keterlibatan } \\
\text { Komunitas }\end{array}$} & \multirow[t]{2}{*}{$\begin{array}{l}\text { Tingkat } \\
\text { Integrasi }\end{array}$} & Kegiatan Integrasi & \multicolumn{2}{|c|}{ Peran Komponen } & \multirow[t]{2}{*}{$\begin{array}{l}\text { Model penempatan } \\
\text { komunitas ini sudah } \\
\text { sesuai dengan best } \\
\text { practice berbasis } \\
\text { bukti }\end{array}$} & \multirow[t]{2}{*}{$\begin{array}{l}\text { Model penempatan } \\
\text { komunitas ini dapat } \\
\text { diterapkan dengan } \\
\text { kondisi di lapangan }\end{array}$} & \multirow[t]{2}{*}{$\begin{array}{l}\text { Catatan } \\
\text { Kritik/Saran }\end{array}$} \\
\hline & & & $\begin{array}{l}\text { layanan kesehatan } \\
\text { mental } \\
\text { - Penyusunan bersama } \\
\text { standar operasi yang } \\
\text { sensitif identitas } \\
\text { budaya/agama }\end{array}$ & $\begin{array}{l}\text { Layanan Kesehatan } \\
\text { untuk ikut serta dalam } \\
\text { komunitas }\end{array}$ & $\begin{array}{l}\text { Komunitas } \\
\text { - Memberikan ruang aman } \\
\text { dan sistem dukungan } \\
\text { (support system) sebagai } \\
\text { bentuk dukungan } \\
\text { psikososial bagi ODHA } \\
\text { dan populasi kunci } \\
\text { - Mengidentifikasi dan } \\
\text { merujuk anggota yang } \\
\text { perlu layanan kesehatan } \\
\text { mental profesional }\end{array}$ & & & \\
\hline $\begin{array}{l}\text { Komunikasi } \\
\text { dan } \\
\text { koordinasi } \\
\text { antar } \\
\text { organisasi } \\
\text { pemberi } \\
\text { layanan, } \\
\text { pasien dan } \\
\text { komunitas/o } \\
\text { rganisasi } \\
\text { komunitas }\end{array}$ & $\begin{array}{l}\text { Dengar } \\
\text { pendapat }\end{array}$ & Kolaborasi & $\begin{array}{l}\text { - Mengidentifikasi isu } \\
\text { prioritas bersama } \\
\text { secara rutin }\end{array}$ & $\begin{array}{l}\text { - Mengidentifikasi dan } \\
\text { menyuarakan isu } \\
\text { prioritas bersama } \\
\text { komunitas }\end{array}$ & $\begin{array}{l}\text { - Mengidentifikasi dan } \\
\text { menyuarakan isu } \\
\text { prioritas bersama } \\
\text { layanan kesehatan }\end{array}$ & $\begin{array}{l}\text { - Sangat tidak setuju } \\
\text { - Tidak setuju } \\
\text { - Netral } \\
\text { - Setuju } \\
\text { - Sangat setuju }\end{array}$ & $\begin{array}{l}\text { - Sangat tidak setuju } \\
\text { - Tidak setuju } \\
\text { - Netral } \\
\text { - Setuju } \\
\text { - Sangat setuju }\end{array}$ & \\
\hline $\begin{array}{l}\text { Pelibatan } \\
\text { aktif } \\
\text { masyarakat } \\
\text { dalam } \\
\text { penelitian } \\
\text { HIV }\end{array}$ & $\begin{array}{l}\text { Crowdsourcing } \\
\text { opini komunitas }\end{array}$ & Kolaborasi & $\begin{array}{l}\text { - Menyusun protokol } \\
\text { penelitian bersama } \\
\text { dengan menampung } \\
\text { perspektif komunitas }\end{array}$ & $\begin{array}{l}\text { - Menyusun protokol } \\
\text { penelitian yang tepat } \\
\text { menurut metodologi } \\
\text { ilmiah }\end{array}$ & $\begin{array}{l}\text { - Menyusun sistem } \\
\text { crowdsourcing untuk } \\
\text { menampung perspektif } \\
\text { komunitas } \\
\text { - Memberi masukan dalam } \\
\text { protokol penelitian } \\
\text { sesuai perspektif } \\
\text { komunitas }\end{array}$ & $\begin{array}{l}\text { - Sangat tidak setuju } \\
\text { - Tidak setuju } \\
\text { - Netral } \\
\text { - Setuju } \\
\text { - Sangat setuju }\end{array}$ & $\begin{array}{l}\text { - Sangat tidak setuju } \\
\text { - Tidak setuju } \\
\text { - Netral } \\
\text { - Setuju } \\
\text { - Sangat setuju }\end{array}$ & \\
\hline
\end{tabular}




\begin{tabular}{|c|c|c|c|c|c|c|c|c|}
\hline \multirow{2}{*}{$\begin{array}{l}\text { Fungsi } \\
\text { Layanan } \\
\text { Kesehatan }\end{array}$} & \multirow{2}{*}{$\begin{array}{l}\text { Kegiatan } \\
\text { Keterlibatan } \\
\text { Komunitas }\end{array}$} & \multirow{2}{*}{$\begin{array}{l}\text { Tingkat } \\
\text { Integrasi }\end{array}$} & \multirow{2}{*}{ Kegiatan Integrasi } & \multicolumn{2}{|c|}{ Peran Komponen } & \multirow{2}{*}{$\begin{array}{l}\text { Model penempatan } \\
\text { komunitas ini sudah } \\
\text { sesuai dengan best } \\
\text { practice berbasis } \\
\text { bukti }\end{array}$} & \multirow{2}{*}{$\begin{array}{l}\text { Model penempatan } \\
\text { komunitas ini dapat } \\
\text { diterapkan dengan } \\
\text { kondisi di lapangan }\end{array}$} & \multirow[t]{2}{*}{$\begin{array}{l}\text { Catatan } \\
\text { Kritik/Saran }\end{array}$} \\
\hline & & & & Layanan Kesehatan & Komunitas & & & \\
\hline $\begin{array}{l}\text { Dukungan } \\
\text { psikososial } \\
\text { dalam } \\
\text { konteks } \\
\text { lokal/kultura } \\
\text { 1/religius }\end{array}$ & $\begin{array}{l}\text { Kelompok } \\
\text { dukungan } \\
\text { sebaya }\end{array}$ & Kolaborasi & $\begin{array}{l}\text { - Saluran rujukan dari } \\
\text { layanan ke komunitas } \\
\text { untuk dukungan } \\
\text { psikososial } \\
\text { - Saluran rujukan dari } \\
\text { komunitas untuk } \\
\text { layanan kesehatan } \\
\text { mental } \\
\text { - Penyusunan bersama } \\
\text { standar operasi yang } \\
\text { inklusif }\end{array}$ & $\begin{array}{l}\text { - Menyusun standar } \\
\text { operasi pelayanan } \\
\text { inklusif bersama } \\
\text { komunitas } \\
\text { - Mengarahkan } \\
\text { pasien/populasi kunci } \\
\text { untuk ikut serta dalam } \\
\text { komunitas }\end{array}$ & $\begin{array}{l}\text { - Menyusun standar } \\
\text { operasi pelayanan } \\
\text { inklusif bersama layanan } \\
\text { kesehatan } \\
\text { - Memberikan ruang aman } \\
\text { dan sistem dukungan } \\
\text { (support system) sebagai } \\
\text { bentuk dukungan } \\
\text { psikososial bagi ODHA } \\
\text { dan populasi kunci } \\
\text { - Mengidentifikasi dan } \\
\text { merujuk anggota yang } \\
\text { perlu layanan kesehatan } \\
\text { mental profesional }\end{array}$ & $\begin{array}{l}\text { - Sangat tidak setuju } \\
\text { - Tidak setuju } \\
\text { - Netral } \\
\text { - Setuju } \\
\text { - Sangat setuju }\end{array}$ & $\begin{array}{l}\text { - Sangat tidak setuju } \\
\text { - Tidak setuju } \\
\text { - Netral } \\
\text { - Setuju } \\
\text { - Sangat setuju }\end{array}$ & \\
\hline & $\begin{array}{l}\text { Dukungan } \\
\text { komunitas } \\
\text { kultural/religiou } \\
\text { s }\end{array}$ & Kolaborasi & $\begin{array}{l}\text { - Saluran rujukan dari } \\
\text { layanan ke komunitas } \\
\text { untuk dukungan } \\
\text { psikososial } \\
\text { - Saluran rujukan dari } \\
\text { komunitas untuk } \\
\text { layanan kesehatan } \\
\text { mental } \\
\text { - Penyusunan bersama } \\
\text { standar operasi yang } \\
\text { sensitif identitas } \\
\text { budaya/agama }\end{array}$ & $\begin{array}{l}\text { - Menyusun standar } \\
\text { operasi pelayanan } \\
\text { sensitive identitas } \\
\text { budaya dan agama } \\
\text { - Mengarahkan } \\
\text { pasien/populasi kunci } \\
\text { untuk ikut serta dalam } \\
\text { komunitas }\end{array}$ & $\begin{array}{l}\text { - Menyusun standar } \\
\text { operasi pelayanan } \\
\text { sensitive identitas } \\
\text { budaya/agama bersama } \\
\text { layanan kesehatan } \\
\text { - Memberikan ruang aman } \\
\text { dan sistem dukungan } \\
\text { (support system) sebagai } \\
\text { bentuk dukungan } \\
\text { psikososial bagi ODHA } \\
\text { dan populasi kunci } \\
\text { - Mengidentifikasi dan } \\
\text { merujuk anggota yang } \\
\text { perlu layanan kesehatan } \\
\text { mental profesional }\end{array}$ & $\begin{array}{l}\text { - Sangat tidak setuju } \\
\text { - Tidak setuju } \\
\text { - Netral } \\
\text { - Setuju } \\
\text { - Sangat setuju }\end{array}$ & $\begin{array}{l}\text { - Sangat tidak setuju } \\
\text { - Tidak setuju } \\
\text { - Netral } \\
\text { - Setuju } \\
\text { - Sangat setuju }\end{array}$ & \\
\hline
\end{tabular}




\section{Daftar Pustaka}

${ }^{1}$ Handler A, Issel M, Turnock B. A conceptual framework to measure performance of the public health system. Am J Public Health. 2001;91(8):1235-9

2 Presiden RI. Peraturan Presiden Republik Indonesia Nomor 72 Tahun 2012 tentang Sistem Kesehatan Nasional. Jakarta: Presiden Republik Indonesia; 2012

${ }^{3}$ Underwood C, Hendrickson Z, Van Lith LM, Kunda JEL, Mallalieu EC. Role of community-level factors across the treatment cascade: a critical review. JAIDS J Acquir Immune Defic Syndr. 2014;66:S311-8

${ }^{4}$ Hafner T and Shiffman J. The emergence of global attention to health systems strengthening. Health Policy Plan 2013; 28: 41-50

${ }^{5}$ Sundewall J, Swanson RC, Betigeri A, et al. Health-systems strengthening, current and future activities. Lancet 2011; 377: 1222-1223

${ }^{6}$ Swanson R, Cattaneo A and Bradley E. Rethinking health systems strengthening, key systems thinking tools and strategies for transformational change. Health Policy Plan 2012; 27: iv54-iv61

${ }^{7}$ Kickbusch I and Reddy KS. Community matters - why outbreak responses need to integrate health promotion. Glob

Health Promot 2016; 23: 75-78.

8 Khongsai, L., Anal, T.S.S.C., A.S., R. et al. Combating the Spread of COVID-19 Through Community Participation. Glob Soc Welf 8, 127-132 (2021)

${ }^{9}$ UNAIDS. An ambitious treatment target to help end the AIDS epidemic, 2014

${ }^{10}$ Negin J, Wariero J, Mutuo P, et al. Feasibility, acceptability and cost of home-based HIV testing in rural Kenya. Trop Med Int Health 2009;14:849-55

11 Suthar AB, Ford N, Bachanas PJ, et al. Towards universal voluntary HIV testing and counselling: a systematic review and meta-analysis of community-based approaches. PLoS Med 2013;10:1-23.

${ }^{12}$ Chamie G, Clark TD, Kabami J, et al. A hybrid mobile approach for population-wide HIV testing in rural east Africa: an observational study. Lancet HIV 2016;3:e111-19

${ }^{13}$ Sharma M, Ying R, Tarr G, et al. Systematic review and meta-analysis of community and facility-based HIV testing to address linkage to care gaps in sub-Saharan Africa. Nature 2015;528:S77-85

${ }^{14}$ Mwai GW, Mburu G, Torpey K, et al. Role and outcomes of community health workers in HIV care in subSaharan Africa: a systematic review. J Int AIDS Soc 2013;16:18586

${ }^{15}$ Decroo T, Rasschaert F, Telfer B, et al. Community-based antiretroviral therapy programs can overcome barriers to retention of patients and decongest health services in sub-Saharan Africa: a systematic review. Int Health 2013;5:169-79

${ }^{16}$ Kementerian Kesehatan RI. Laporan Survei Terpadu Biologi dan Perilaku pada Populasi Kunci HIV di Indonesia Tahun 2018. Jakarta; Kemenkes; 2019.

${ }^{17}$ Resch S, Ryckman T, Hecht R. Funding AIDS programmes in the era of shared responsibility: an analysis of domestic spending in 12 low-income and middle-income countries. Lancet Glob Heal 2015;3: e5261.

${ }^{18}$ Mak J, Birdthistle I, Church K, et al. Need, demand and missed opportunities for integrated reproductive health-HIV care in Kenya and Swaziland: evidence from household surveys. AIDS 2013;27 (Suppl 1):S5563 
${ }^{19}$ Mak J, Birdthistle I, Church K, et al. Need, demand and missed opportunities for integrated reproductive health-HIV care in Kenya and Swaziland: evidence from household surveys. AIDS 2013;27 (Suppl 1):S5563

${ }^{20}$ Church K, de Koning K, Martin-Hiber A, et al. Integrating sexual health services into primary care: an overview of health systems issues and challenges in developing countries. Int J Sex Heal 2010;22:13143.

${ }^{21}$ Januraga PP, Sutrisna A, Darmawi V, Praptoraharjo I, Suharni M, Hersumpana I, et al. HIV Prevention through Sexual Transmission Model at the Primary Health Care Level. Yogyakarta: Center for Policy and Health Management (CHPM), Faculty of Medicine, Universitas Gadjah Mada; 2016.

${ }^{22}$ Wagner EH. Chronic disease management: what will it take to improve care for chronic illness? Eff Clin Pract. 1998;1(1).

${ }^{23}$ WHO. Innovative care for chronic conditions: building blocks for actions: global report. World Health Organization; 2002

${ }^{24}$ Doherty W, McDaniel S, Baird M. Five levels of primary care/behavioral healthcare collaboration. 1996

${ }^{25}$ Blount A. Integrated primary care: Organizing the evidence. Fam Syst Heal. 2003;21(2):121

${ }^{26}$ Burns PA, Williams MS, Mena LA, Bruce MA, Bender M, Burton ET, et al. Leveraging Community Engagement: The Role of Community-Based Organizations in Reducing New HIV Infections Among Black Men Who Have Sex with Men. J Racial Ethn Heal Disparities. 2020 Apr 1;7(2):193-201.

${ }^{27}$ Maiorana A, Sevelius J, Keatley JA, Rebchook G. "She is Like a Sister to Me." Gender-Affirming Services and Relationships are Key to the Implementation of HIV Care Engagement Interventions with Transgender Women of Color. AIDS Behav. 2020;1:1.

${ }^{28}$ Cabral HJ, Davis-Plourde K, Sarango M, Fox J, Palmisano J, Rajabiun S. Peer Support and the HIV Continuum of Care: Results from a Multi-Site Randomized Clinical Trial in Three Urban Clinics in the United States. AIDS Behav. 2018 Aug 1;22(8):2627-39

${ }^{29}$ Chang LW, Mbabali I, Hutton H, Rivet Amico K, Kong X, Mulamba J, et al. Novel Community Health Worker Strategy for HIV Service Engagement in a Hyperendemic Community in Rakai, Uganda: A Pragmatic, Cluster-Randomized Trial. PLoS Med. 2021 Jan 6;18(1)

${ }^{30}$ Medeossi B-J, Stadler J, Delany-Moretlwe S. 'I Heard about this Study on the Radio': Using Community Radio to Strengthen Good Participatory Practice in HIV Prevention Trials. BMC Public Health. 2014;14(1):1-8

${ }^{31}$ Wood BR, Unruh KT, Martinez-Paz N, Annese M, Ramers CB, Harrington RD, et al. Impact of a Telehealth Program that Delivers Remote Consultation and Longitudinal Mentorship to Community HIV Providers. Open Forum Infect Dis. 2016 Jul 1;3(3)

32 Maiorana A, Kegeles S, Salazar X, Konda K, Silva-Santisteban A, Cáceres C. 'Proyecto Orgullo', an HIV Prevention, Empowerment and Community Mobilisation Intervention for Gay Men and Transgender Women in Callao/Lima, Peru. Glob Public Health [Internet]. 2016 Sep 13 [cited 2021 Apr 29];11(78):1076-92. Available from: https://pubmed.ncbi.nlm.nih.gov/27373578/

${ }_{33}$ Pettifor A, Lippman SA, Selin AM, Peacock D, Gottert A, Maman S, et al. A Cluster Randomized-Controlled Trial of a Community Mobilization Intervention to Change Gender Norms and Reduce HIV Risk in Rural South Africa: Study Design and Intervention. BMC Public Health. 2015 Aug 6;15(1).

${ }^{34}$ Coates TJ, Kulich M, Celentano DD, Zelaya CE, Chariyalertsak S, Chingono A, et al. Effect of CommunityBased Voluntary Counselling and Testing on HIV Incidence and Social and Behavioural Outcomes (NIMH Project Accept; HPTN 043): A Cluster-Randomised Trial. Lancet Glob Heal. 2014;2(5)

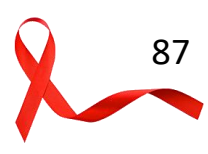


35 Tedrow VA, Zelaya CE, Kennedy CE, Morin SF, Khumalo-Sakutukwa G, Sweat MD, et al. Nomor "Magic Bullet": Exploring Community Mobilization Strategies used in a Multi-Site Community based Randomized Controlled Trial: Project Accept (HPTN 043). AIDS Behav. 2012 Jun;16(5):1217-26

${ }^{36}$ Koester KA, Morewitz M, Pearson C, Weeks J, Packard R, Estes M, et al. Patient navigation facilitates medical and social services engagement among HIV-infected individuals leaving jail and returning to the community. AIDS Patient Care STDS [Internet]. 2014 Feb 1 [cited 2021 Apr 29];28(2):82-90. Available from: https://pubmed.ncbi.nlm.nih.gov/24517539/

${ }^{37}$ Bradford JB, Coleman S, Cunningham W. HIV system navigation: An emerging model to improve HIV care access. AIDS Patient Care STDS [Internet]. 2007 Jun [cited 2021 Apr 29];21(SUPPL. 1). Available from: https://pubmed.ncbi.nlm.nih.gov/17563290/

${ }^{38}$ Loos J, Manirankunda L, Platteau T, Albers L, Fransen K, Vermoesen T, et al. Acceptability of a CommunityBased Outreach HIV-Testing Intervention Using Oral Fluid Collection Devices and Web-Based HIV Test Result Collection among Sub-Saharan African migrants: A mixed-method study. JMIR Public Heal Surveill. 2016 Jul 1;2(2)

${ }^{39}$ Sindelar K, Maponga C, Lekoala F, Mandara E, Mohoanyane M, Sanders J, et al. Beyond the Facility: An Evaluation of Seven Community-based Pediatric HIV Testing Strategies and Linkage to Care Outcomes in a High Prevalence, Resource-Limited Setting. Yotebieng M, editor. PLoS One. 2020 Sep 2;15(9):e0236985

${ }^{40}$ Young BA, Rosenthal A, Escarfuller S, Shah S, Carrasquillo O, Kenya S. Beyond the Barefoot Doctors: Using Community Health Workers to Translate HIV Research to Service. AIDS Behav. 2019 Oct 1;23(10):287988

${ }^{41}$ Mwango LK, Stafford KA, Blanco NC, Lavoie MC, Mujansi M, Nyirongo N, et al. Index and Targeted Community-based Testing to Optimize HIV Case Finding and ART Linkage Among Men in Zambia. J Int AIDS Soc. 2020 Jun 1;23(S2)

${ }^{42}$ Macharia LW, Wexler C, Brown M, Maloba M, Pricilla RA, Mabachi NM, et al. Implementation Planning for Community-Based Point-of-Care HIV Testing for Infants: Recommendations from Community Leaders in Kenya. Ito E, editor. PLoS One. 2020 Oct 15;15(10):e0240476

${ }^{43}$ Fu X, Qi J, Hu Y, Pan X, Li Y, Liu H, et al. Partner Notification in Cooperation with Community-Based Organizations among HIV-Positive Men who have Sex with Men in Two Chinese Cities. Int J STD AIDS. 2016 Sep 1;27(10):821-31

${ }^{44}$ Chamie G, Kwarisiima D, Clark TD, Kabami J, Jain V, Geng E, et al. Leveraging Rapid Community-based HIV Testing Campaigns for Non-Communicable Diseases in Rural Uganda. PLoS One. 2012 Aug 20;7(8)

${ }^{45}$ Rasschaert F, Decroo T, Remartinez D, Telfer B, Lessitala F, Biot M, et al. Sustainability of a Communitybased Anti-Retroviral Care Delivery Model - A Qualitative Research Study in Tete, Mozambique. J Int AIDS Soc. 2014;17(1)

${ }^{46}$ Kemp C, Gerth-Guyette E, Dube L, Andrasik M, Rao D. Mixed-Methods Evaluation of a Novel, Structured, Community-Based Support and Education Intervention for Individuals with HIV/AIDS in KwaZulu-Natal, South Africa. AIDS Behav. 2016 Sep 1;20(9):1937-50

${ }^{47}$ Bemelmans M, Baert S, Goemaere E, Wilkinson L, Vandendyck M, van Cutsem G, et al. CommunitySupported models of Care for People on HIV Treatment in Sub-Saharan Africa. Trop Med Int Heal. 2014;19(8):968-77

${ }^{48}$ Mantell JE, Masvawure TB, Mapingure M, Apollo T, Gwanzura C, Block L, et al. Engaging men in HIV Programmes: a Qualitative Study of Male Engagement in Community-based Antiretroviral refill Groups in Zimbabwe. J Int AIDS Soc. 2019 Oct 1;22(10)

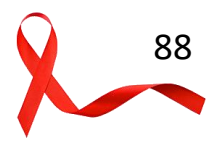


${ }^{49}$ Scott K, Campbell C, Madanhire C, Skovdal M, Nyamukapa C, Gregson S. In What Ways do Communities Support Optimal Antiretroviral Treatment in Zimbabwe? Health Promot Int. 2014 Dec 1;29(4):645-54

50 Wilson TE, Fraser-White M, Williams KM, Pinto A, Agbetor F, Camilien B, et al. Barbershop Talk with Brothers: Using Community-based Participatory Research to Develop and Pilot Test a Program to Reduce HIV Risk among Black Heterosexual Men. AIDS Educ Prev. 2014 Sep 14;26(5):383-97

${ }^{51}$ Woods-Jaeger BA, Carlson M, Taggart T, Riggins L, Lightfoot AF, Jackson MR. Engaging African American Faith-Based Organizations in Adolescent HIV Prevention. J Relig Health. 2015 Aug 11;54(4):1358-74

${ }^{52}$ O'Laughlin KN, Wyatt MA, Kaaya S, Bangsberg DR, Ware NC. How Treatment Partners Help: Social Analysis of an African Adherence Support Intervention. AIDS Behav. 2012 Jun;16(5):1308-15

53 Salmen CR, Hickey MD, Fiorella KJ, Omollo D, Ouma G, Zoughbie D, et al. "Wan Kanyakla" (We Are Together): Community Transformations in Kenya Following a Social Network Intervention for HIV Care. Soc Sci Med. 2015 Dec 1;147:332-40

${ }^{54}$ Shamu S, Slabbert J, Guloba G, Blom D, Khupakonke S, Masihleho N, et al. Linkage to Care of HIV Positive Clients in a community based HIV Counselling and Testing Programme: A Success Story of NonGovernmental Organisations in a South African District. Maulsby C, editor. PLoS One. 2019 Jan 22;14(1):e0210826

${ }^{55}$ Riehman KS, Kakietek J, Manteuffel BA, Rodriguez-García R, Bonnel R, N'Jie N, et al. Evaluating the Effects of Community-based Organization Engagement on HIV and AIDS-related Risk Behavior in Kenya. AIDS Care - Psychol Socio-Medical Asp AIDS/HIV. 2013;25(SUPPL.1)

${ }^{56}$ Kuhlmann AS, Galavotti C, Hastings P, Narayanan P, Saggurti N. Investing in Communities: Evaluating the Added Value of Community Mobilization on HIV Prevention Outcomes among FSWs in India. AIDS Behav. 2014;18(4):752-66

${ }^{57}$ Day S, Mathews A, Blumberg M, Vu T, Rennie S, Tucker JD. Broadening Community Engagement in Clinical Research: Designing and Assessing a Pilot Crowdsourcing Project to Obtain Community Feedback on an HIV Clinical Trial. Clin Trials. 2020 Jun 1;17(3):306-13

58 Zhao Y, Day S, Yang NS, Bao H, Li L, Mathews A, et al. Crowdsourcing Contests to Facilitate Community Engagement in HIV Cure Research: A Qualitative Evaluation of Facilitators and Barriers of Participation. BMC Public Health [Internet]. 2020 Jan 15 [cited 2021 Apr 29];20(1):67. Available from: https://bmcpublichealth.biomedcentral.com/articles/10.1186/s12889-020-8185-z

59 Morgan J, Schwartz C, Ferlatte O, Mniszak C, Lachowsky N, Jollimore J, et al. Community-Based Participatory Approaches to Knowledge Translation: HIV Prevention Case Study of the Investigaytors Program. Arch Sex Behav. 2021 Jan 1;50(1):105-17

${ }^{60}$ O'Brien KK, Bayoumi AM, King K, Alexander R, Solomon P. Community Engagement in Health Status Instrument Development: Experience with the HIV Disability Questionnaire. Prog Community Heal Partnerships Res Educ Action. 2015;8(4):549-59

${ }^{61}$ UNAIDS. Community, Engaging the 90-90-90, to reach Malawi, A review of evidence and implementation strategies in. 2015

62 Singgi ADD, Zakiah NR. Kajian Hukum dan Kebijakan HIV di Indonesia, Sebuah Tinjauan terhadap Peraturan Perundang-Undangan dan Implementasinya di Enam Kota/Kabupaten. Jakarta; 2017

${ }^{63}$ Kementerian Kesehatan Republik Indonesia. Kampanye Bulan Viral Load: Pentingnya Mengetahui Status Pengobatan ART pada ODHA Melalui Pemeriksaan Viral Load HIV. kemkes.go.id. 2020.

${ }^{64}$ Setiawan E, Soehoed R, Stein D. Tinjauan Hukum dan Regulasi untuk Belanja Kesehatan Strategis Program HIV di Indonesia. 2020 
${ }^{65}$ Mahendra GK. Analisis Dampak Penghentian Tugas Kpa Kota Yogyakarta Berdasarkan Peraturan Presiden Nomor 124 Tahun 2016. Kebijak J Ilmu Adm. 2019;10(2):94-

66 Yoshikawa MJ, Kusriastuti R. WHO country cooperation strategy 2007-2011: Indonesia WHO country cooperation strategy 2007-2011: Indonesia, 2008. Trop Med Health. 2013;41(2):67-78

${ }^{67}$ PMK FK UGM. Pelaksanaan Desentralisasi Kesehatan di Indonesia 2000-2007: Mengkaji Pengalaman dan Membahas Skenario Masa Depan. 2009 


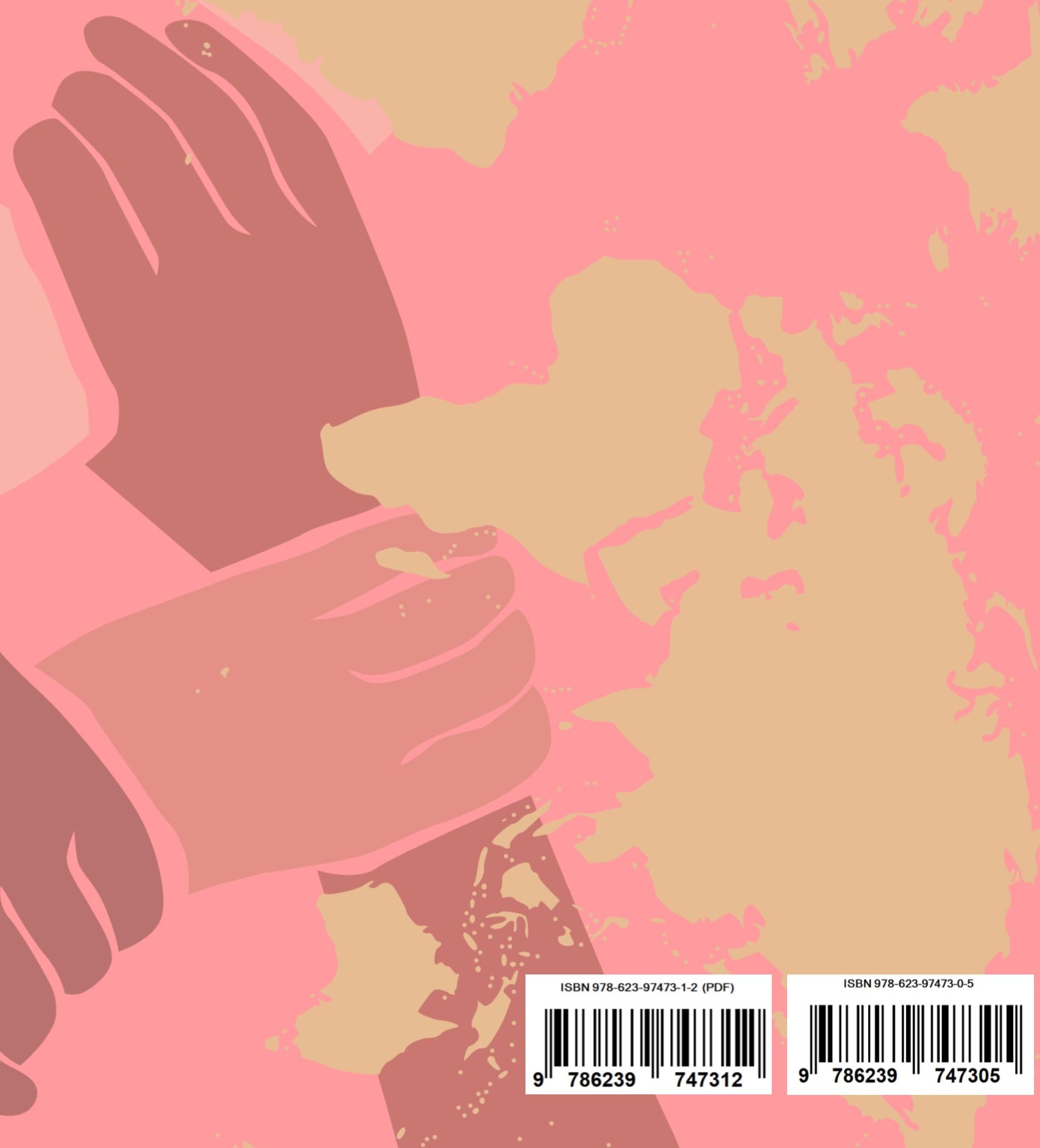

